This dissertation has been microfilmed exactly as received $\quad 68-15,397$

WOLFE, D.V.M., Lauren Gene, 1939EXPERIMENTAL AEROSOL TRANSMISSION OF YABA VIRUS IN MONKEYS.

The Ohio State University, Ph.D., 1968

Health Sciences, pathology

University Microfilms, Inc., Ann Ārbor, Michigan 


\title{
EXPERIMENTAL AEROSOL TRANSMISSION OF
}

YABA VIRUS IN MONKEYS

\section{DISSERTATION}

\section{Presented in Partial Fulfillment of the Requirenents for the Degree Doctor of Philosophy in the Graduate School of The Ohio State University}

\author{
By \\ Lauren Gene Tolfe, D.V.M., M.Sc. \\ $* * * * * *$ \\ The Ohio State University \\ 1968
}

Approved by

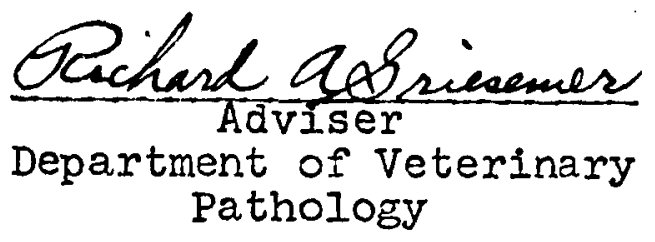




\section{ACKNOWLEDGMENTS}

The author expresses his sincere gratitude to his adviser, Dr. Richard A. Griesemer, Professor and Chairman, Department of Veterinary Pathology, The Ohio State University, for his guidance, scholarly advice and encouragement during this investigation and throughout the graduate program. The author also expresses his deepest appreciation to Dr. Charles C. Capen, Associate Professor of Veterinary Pathology, for the constructive criticism and inspirational philosophy that he contributed throughout the author's graduate education.

Dean Clarence $R$. Cole is extended a special acknowledgment for providing the author an opportunity to pursue a career in comparative pathology. Professors Robert Farrell and Adalbert Koestner are thanked for their constructive criticism and co-operation throughout the author's graduate training.

The assistance and dedication of the technical staff of the Department of Veterinary Pathology have contributed Immeasurably to this investigation and to them the author is greatly indebted.

The author also expresses his sincere appreciation to his wife, Virginia, for her patience and understanding. 


\section{VITA}

November 7, 1939 Born--Kenton, Ohio

1963 - . . . D.V.M., The Ohio State University, Columbus, Ohio

1965 . . . M.Sc., The Ohio State University, Columbus, Ohio

1963-1968 - . N.I.H. Trainee, Department of Veterinary Pathology, The Ohio State University, Columbus, Ohio

\section{PUBLICATIONS}

"Feline Infectious Peritonitis." Path. Vet., Vol. 3, pp. 255-270, 1966

"Germfree Cynomolgus Monkeys." Lab. Animal Care, Vol. 16, pp. 364-368, 1966

"The Germfree Cat." Lab. Animal Care, Vol. 16, pp. 52-59, 1966

\section{FIELDS OF STUDY}

Major Field: Veterinary Pathology

Studies in Viral Oncology. Professor Richard A. Griesemer

Studies in Pathology of Infectious Diseases. Professor Richard A. Griesemer

Studies In Gnotobiology. Professor Richard A. Griesemer

Studies In Animal Oncology. Professor Adalbert Koestner

Studies in Comparative Neuropathology. Professor Adalbert Koestner

Studies in Medical Pathology. Professor Dante Scarpelli 


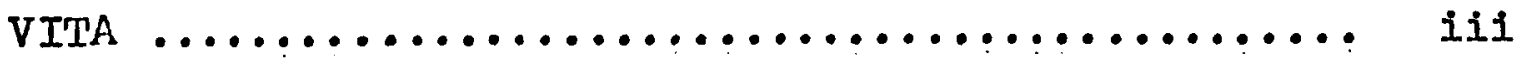

TABLES ................................. v v

ILLUSTRATIONS ........................... vi

Chapter

I. EXPERIMENTAI AEROSOI TRANSMISSION OF YABA VIRUS IN MONKEYS ................... 1

Introduction $\ldots \ldots \ldots \ldots \ldots \ldots \ldots \ldots \ldots \ldots \ldots \ldots \ldots \ldots$

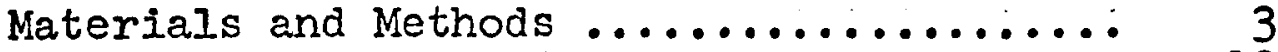

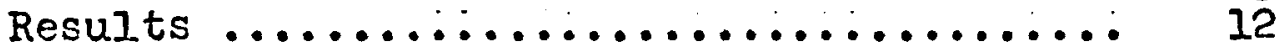

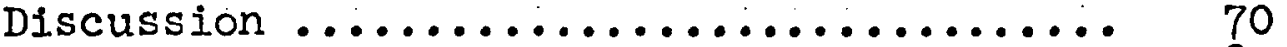

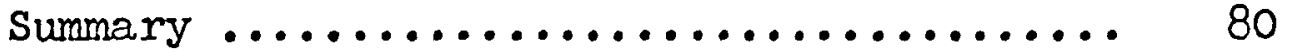

II. IMMUNOLOGIC RESPONSE OF MONKEYS TO AEROSOLS

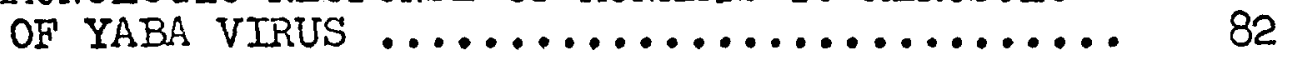

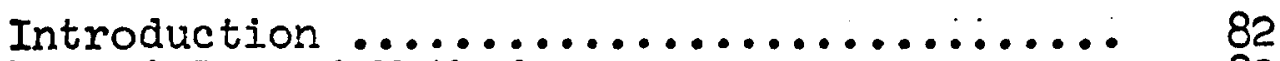

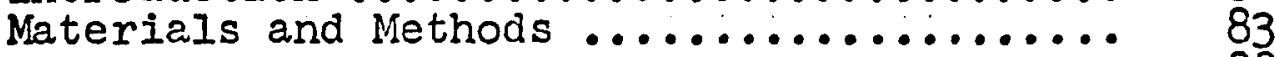

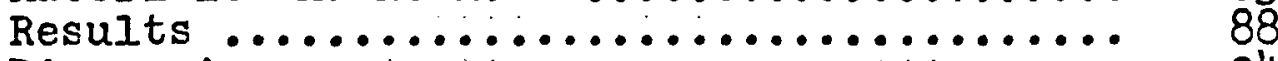

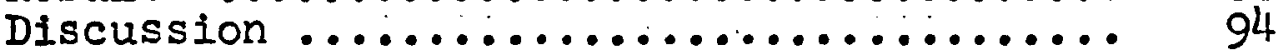

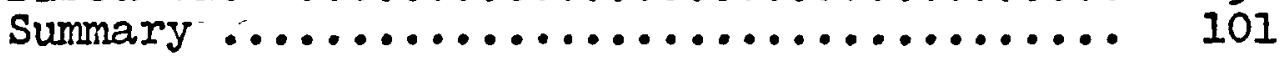

III. GERMFREE CYNOMOLGUS MONKEYS . . . . . . . . . . . . . 102

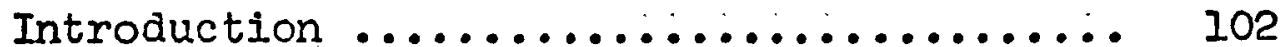

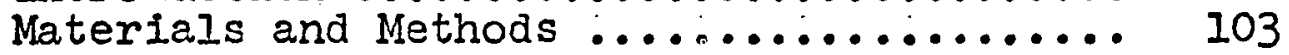

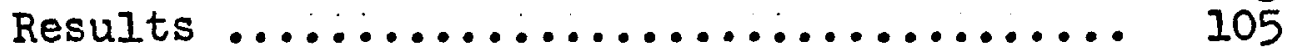

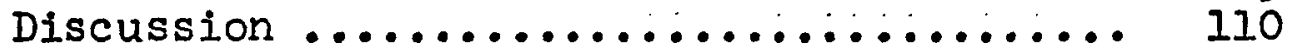

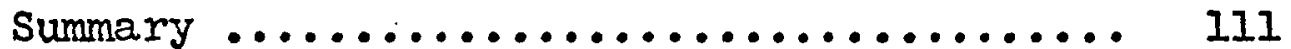

IV. RESISTANCE OF A GERMEREE MONKEY TO HUMAN

VIRAI HEPATITIS .................... 112

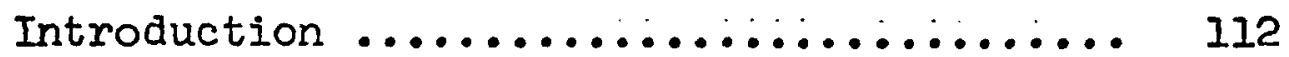

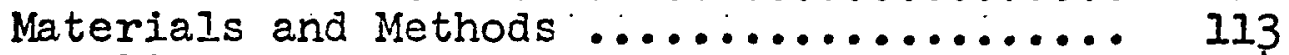

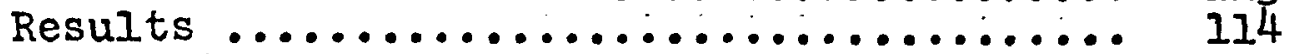

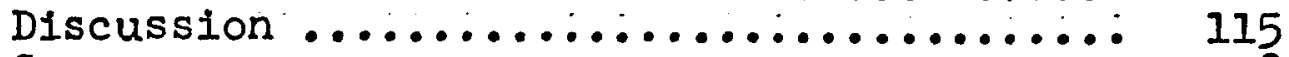

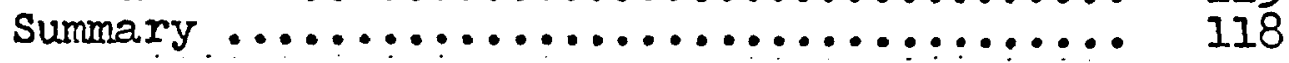

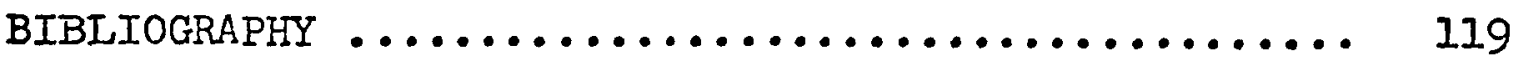




\section{TABLES}

Table

Page

1. Clinical Data and Schedule of Euthanasia on 16 Monkeys Exposed to a Yaba Virus Aerosol.

2. Exposure Data on 16 Monkeys Exposed to a Yaba Virus Aerosol

3. Distribution of Yaba Virus-Induced Pulmonary

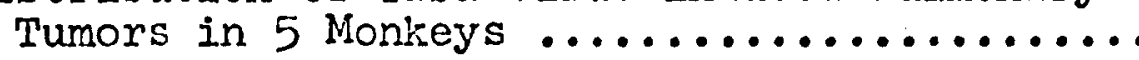

4. Titer (FFU/gm) of Yaba Virus in Lung Tumors and in Lung Tissue Adjacent to the Tumors ..

5. Complement-Fixing Antibody Titers in 5 Aerosol-Exposed and 3 SubcutaneouslyInoculated Monkeys with Yaba Virus-Induced Tumors (STE Antigen)

6. Comparison of the CF Antibody Titers Detected by 3 Different Antigen Preparations in 4 Monkeys with Yaba Virus-Induced Pulmonary Tumors

7. Weights of Germfree and Control Cynomolgus Monkeys (grams)

8. Deciduous Tooth Eruption in Germfree Cynomolgus Monkeys

9. Serum Enzyme Values of a Monkey Exposed to Human Infectious Hepatitis 


\section{ILLUSTRATIONS}

Figure

Page

1. Photograph of a nasal tumor in a monkey 9 weeks after aerosol exposure to Yaba virus ... 14

2. Photograph of the nasal tumor 12 weeks after exposure, representing its maximal size ..... 16

3. Radiograph of the masal tumor 13 weeks after

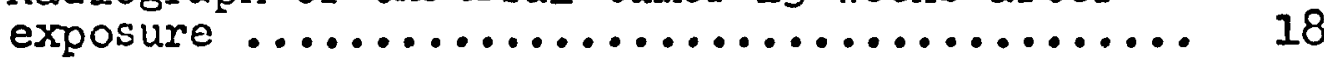

4. Photograph of the monkey in Figures $1-3$ 15 weeks after exposure illustrating a dorsal opening into the nasal cavity ....... 21

5. Photograph illustrating complete regression of the nasal tumor and healing of the tumor

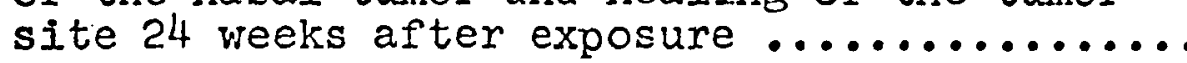

6. Photograph of subcutaneous tumors on the tail and perineum of an aerosol-exposed monkey

7. Photograph of pulmonary tumors in a monkey necropsied 12 weeks after aerosol exposure to Yaba virus

8. Photograph of a Iarge tumor in Figure 7 sectioned transversely

9. Photograph of a pulmonary tumor with central necrosis in a monkey necropsied 8 weeks after exposure

10. Photomicrograph of lung from a monkey necropsied 4 weeks after aerosol exposure to Yaba virus ...

11. Photomicrograph of a well-demarcated lung tumor in a monkey necropsied 12 weeks after exposure

12. Photomicrograph illustrating intracytoplasmic inclusion bodies within the tumor cells shown in Figure 11 
Figure

13. Photomicrograph of a peribronchial lymphatic filled with tumor cells in a monkey necropsied 6 weeks after exposure ......... 45

14. Electron micrograph illustrating abundant cytoplasmic organelies in a tumor cell from the lung of an aerosol-exposed monkey ...... 50

15. Electron micrograph illustrating viral replication in a granular pneumonocyte ..... 52

16. Electron micrograph demonstrating membranous honeycornbed structures adjacent to a site of viral synthesis in a tumor cell .......... 54

17. Electron micrograph of a well-demarcated area within the cytoplasm of a tumor cell in the lung, representing an early site of viral

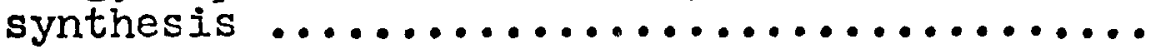

18. Electron micrograph illustrating formation of immature viral particles in a tumor cell.

19. Electron micrograph of an inclusion body containing several mature viral particles ...

20. Electron micrograph illustrating crystalline aggregates in capillary endothelial cells within a Yaba virus-induced subcutaneous

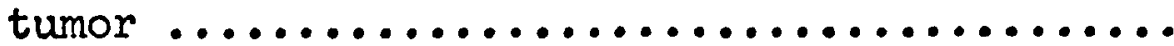

21. Photograph of tumors in skeletal muscles of a monkey 3 weeks after intravenous inocula-

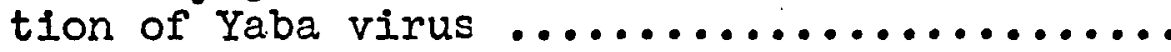

22. Photograph of tumor nodules on the costal and diaphragmatic pleurae of a monkey 3 weeks after intrathoracic inoculation of Yaba

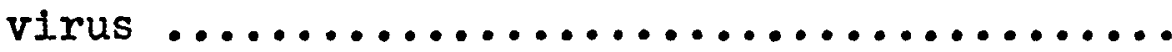

23. Photograph of multiple subcutaneous tumors on the thighs and perineum of a monkey 5 weeks after intrapulmonic inoculation of Yaba virus

24. Graph illustrating complement-fixing antibody titers in a monkey which developed a nasal tumor and multiple subcutaneous tumors after aerosol exposure to Yaba virus ........... 90 
Figure

Page

25. Immunofluorescence. Demonstration of viral antigen in tumor cells from the lung of an animal necropsied 12 weeks after aerosol exposure to Yaba virus 
CHAPTER I

EXPERIMENTAI AEROSOL TRANSMISSION OF

YABA VIRUS IN MONKEYS

\section{Introduction}

Virus-induced animal tumors have been experimentally transmitted to susceptible animal species by several routes but the risk associated with exposure of man and animals to aerosols of oncogenic viruses has not been evaluated. Information regarding the susceptibility of animals to aerosolized oncogenic viruses would be valuable as a guide for protecting laboratory personnel who work with highly concentrated preparations of oncogenic viruses and for preventing cross contamination of experimental animals. Since aerosol exposure is a common mode of transmission for many virus diseases, oncogenic viruses might concelvably enter through the respiratory tract of susceptible hosts including man. Rauscher murine leukemia (I) and avian leukosis $(2,3)$ have already been transmitted by aerosols to mice and chickens respectively but aerosol transmission of DNA tumor viruses has not been reported.

Yaba virus, a DNA poxvirus (4-6), was originally isolated from tumor material collected during an epizootic of self-limiting subcutaneous histiocytomas in a monkey 
colony at Yaba, Nigeria (7). It was selected for study of aerosol transmission because: (a) it can be readily assayed in vitro (8), (b) the experimental host, the monkey, has a comparatively large minute respiratory volume, (c) the virus induces lung tumors in monkeys following intravenous fnoculation, implicating lung as a susceptible tissue (9), and (d) it is oncogenic for man as well as monkeys. Experimentally induced subcutaneous tumors in man are indistinguishable microscopically from the naturally occurring and experimentally induced tumors in monkeys (10).

The objectives of this study were: (a) to determine the susceptibility of monkeys to dynamic aerosols of Yaba virus, (b) to compare the biological behavior of tumors induced via the respiratory route to previously described tumors induced by the subcutaneous route, (c) to compare virus replication in pulmonary tumors to that previously reported in subcutaneous tumors, (d) to evaluate the effect of pre-existing lesions of pulmonary acariasis on the pathogenesis and morphology of the tumors, and (e) to study the role of the respiratory microflora by exposing a germfree monkey to a Yaba virus aerosol. This communication describes the aerosolization procedures and the clinical, pathologic, ultrastructural, and virological findings. Immunologic studies are described in an accompanying report (II). 
Materials and Methods

Animals.--Sixteen rhesus (Macaca mulatta) and 5

cynomolgus (Macaca fascicularis) monkeys were used in the aerosol study. These two species were selected because they are equally susceptible to Yaba virus following subcutaneous inoculation $(4,12)$ and because pulmonary acariasis occurs spontaneously in imported rhesus monkeys but rarely in cynomolgus monkeys. The monkeys were clinically healthy and contained no demonstrable pre-inoculation complementfixing or neutralizing Yaba virus antibodies. of the 16 animals exposed to aerosolized Yaba virus (Table 1 ) 10 were Imported conditioned monkeys and 6 were born and raised in the laboratory. One animal (No. 16) was maintained under germfree conditions (13) until exposed to Yaba virus. One rhesus monkey and 1 cynomolgus monkey were exposed to an aerosol without virus. Three monkeys (2 rhesus and 1 cynomolgus) served as contact-exposed cagemates for 3 aerosol-exposed monkeys and were paired with these animals 2 weeks following aerosolization. The monkeys were kept in wire cages inside rigid or flexible plastic isolators to prevent accidental cross contamination.

Frior to the aerosol exposure experiments, the in vivo infectivity of a Yaba virus-infected cell culture suspension was evaluated following subcutaneous, intravenous, intrapulmonic and intrathoracic inoculations of juvenile rhesus monkeys. Three monkeys were inoculated subcutaneously 
Table 1. Clinical Data and Schedule of Euthanasia on 16 Monkeys Exposed to a Yaba Virus Aerosol.

\begin{tabular}{|c|c|c|c|c|c|}
\hline $\begin{array}{l}\text { Monkey } \\
\text { No. }\end{array}$ & Species & $A g e^{a}$ & Sex & $\begin{array}{l}\text { Weight } \\
(\mathrm{kg})\end{array}$ & $\begin{array}{l}\text { Euthanasia } \\
\text { (weeks PE) }\end{array}$ \\
\hline 1 & $\mathrm{R}$ & $\mathbf{J}$ & $\mathrm{Fe}$ & 1.8 & 5 \\
\hline 2 & $\mathrm{R}$ & $\mathrm{J}$ & M & 1.8 & 4 \\
\hline 3 & $\mathbf{R}$ & $\mathrm{J}$ & $\mathrm{Fe}$ & 1.8 & 8 \\
\hline 4 & $\mathrm{R}$ & $\mathrm{J}$ & $\mathrm{Fe}$ & 1.8 & 4 \\
\hline 5 & $\mathrm{R}$ & $\mathrm{J}$ & M & 1.8 & 10 \\
\hline 6 & $\mathrm{R}$ & $\mathrm{N}$ & M & 0.4 & 6 \\
\hline 7 & $\mathrm{R}$ & A & $\mathrm{Fe}$ & 3.6 & 12 \\
\hline 8 & $\mathrm{R}$ & $\mathrm{J}$ & M & 1.8 & $0^{b}$ \\
\hline 9 & $\mathbf{R}$ & $J$ & M & 1.8 & 2 \\
\hline 10 & $\mathrm{R}$ & $\mathbf{J}$ & $\mathrm{Fe}$ & 1.8 & 14 \\
\hline 11 & $\mathbf{R}$ & 15 & M & 1.8 & 16 \\
\hline 12 & $\mathrm{R}$ & 14 & M & 1.6 & $\mathrm{NE}$ \\
\hline 13 & C & 30 & $\mathrm{Fe}$ & 2.7 & 10 \\
\hline 14 & C & 30 & $\mathrm{Fe}$ & 2.7 & 4 \\
\hline 15 & C & $\mathrm{J}$ & M & 2.3 & 16 \\
\hline 16 & R & 12 & $\mathrm{M}$ & 2.3 & 12 \\
\hline
\end{tabular}

age of the hand-reared monkeys expressed in months.

${ }^{b}$ Animal euthanatized immediately after exposure to determine dose of virus retained in the lungs.

$\mathrm{R}=$ rhesus; $\mathrm{C}=$ cynomolgus; $\mathrm{N}=$ newborn; $\mathrm{A}=$ adult; $J=$ juvenile; $N E=$ not euthanatized, alive at 24 weeks after exposure; $P E=$ post exposure. 
with 20 focus forming units (FFU) of virus, I intravenously with $2 \times 10^{5} \mathrm{FFU}, 1$ intrathoracically (bilateral) with $5 \times 10^{4} \mathrm{FFU}$ and 1 intrapulmónically (bilateral) with $1 \times 10^{5} \mathrm{FFU}$.

Cell culture.--A Cercopithecus aethiops monkey kidney cell line $(\mathrm{CV}-1)^{1}$ was used for virus assay procedures and for producing the aerosol inoculum. The cells from the sixty-fifth through the ninety-fifth passages were propagated in medium 199 supplemented with 10\% agamma calf serum and were maintained in medium 199 with $2 \%$ agamma calf serum. The medium was changed twice weekly.

Assay procedures.--The virus assays were performed on confluent monolayers of CV-1 cells grown on $11 \times 35 \mathrm{~mm}$ coverslips in Leighton tubes. Ten-fold dilutions of virus suspensions were made in medium 199 diluted 1:1 with bovine amniotic fluid and $0.4 \mathrm{ml} /$ tube was added to 4 tubes/dilution. Adsorption was carried out at $25^{\circ} \mathrm{C}$ for approximately 18 hours (8). The infected coverslip cultures were incubated at $35^{\circ} \mathrm{C}$ for 17 or 18 days after which they were fixed in Bouin's fluid and stained with hematoxylin and eosin. Titers of virus preparations were expressed as the number of focus forming units (FFU)/ml. The cytopathic effect was consistently manifested as microtumor formation (14).

$I_{\text {The }} \mathrm{CV}-\mathrm{I}$ cell line was obtained from Dr. D. Yohn, Roswell Park Memorial Institute, Buffalo, New York. 
Inoculum.--Yaba virus was provided as a Yaba virusinduced subcutaneous tumor by Dr. D. Yohn, Roswell Park Memorial Institute, Buffalo, New York. Two rhesus monkeys were injected at multiple subcutaneous sites with the original tumor homogenate. The tumors which developed were surgically excised 2-3 weeks post-inoculation (PI), and the tumor homogenate was layered onto confluent monolayers of CV-I cells grown in $100 \mathrm{ml}$ prescription bottles. The infected cell cultures were harvested and the virus serially passaged at 24-28 days PI. The inocula for aerosolization were prepared from the second through the fifth passages. The infected cells were scraped from the glass surfaces, centrifuged lightly, suspended ( $1 \mathrm{ml} /$ bottle scraped) in medium 199 and 10\% agamma calf serum at pH 7.2-7.4, ruptured by 4 freeze-thaw cycles, and centrifuged at $600 \mathrm{xg}$ for 10 minutes. The titer of virus in the supernatants ranged from $1 \times 10^{5}$ to $4 \times 10^{6} \mathrm{FFU} / \mathrm{ml}$. The total protein concentration of the inocula ranged from 400 to $1000 \mathrm{mg} / 100 \mathrm{ml}$. Aerosol exposure.--The animals were exposed to a dynamic aerosol of Yaba virus which was generated in a collison atomizer in a Henderson apparatus (15). The total air flow through the exposure unit was maintained at 12.5 liters/minute. The relative humidity of the aerosol was 80-85\% at the onset of exposure but gradually increased until it exceeded 95\% after 1 hour. It was determined in a preliminary study that Yaba virus was stable at these 
relative humidity levels. The aerosol was sampled periodically in glass impingers containing cell culture media, and subsequently titered to determine the number of $\mathrm{FFU} / \mathrm{ml}$ of inhaled air.

Fifteen monkeys were exposed in 5 groups of 3/group and the germfree monkey was exposed separately (Table 2). One group of rhesus monkeys was exposed for 90 minutes (Group 2) and the others were exposed for 150 minutes. For the group exposures, 3 monkeys of the same species were placed in a 3-tier rigid plastic exposure box that was located inside a freon-tight cabinet system maintained under negative pressure. For exposure of the germfree monkey the collison spray device and the stainless steel exposure box (16) were placed inside a germfree flexible plastic isolator and the compressed air used for generating the aerosol was filtered before it reached the nebulizer. All of the monkeys except the newborn were administered phencyclidine hydrochloride prior to exposure.

For determining the particle size of the aerosol, Yaba virus was collected in an Andersen sampler (17). The plates were prepared with a $21 \mathrm{ml}$ hard agar base and a $6 \mathrm{ml}$ gelatin overlay. After sampling, the gelatin in the plates was liquefied and was removed for virus assay. Approximately 50\% of the infectivity was in the particle size range of 1-3 u. Of the remaining infectivity, $10 \%$ was associated with particles larger than $8 \mathrm{u}$. 
Table 2. Exposure Data on 16 Monkeys Exposed to a Yaba Virus Aerosol.

\begin{tabular}{|c|c|c|c|c|}
\hline $\begin{array}{l}\text { Group } \\
\text { No. }\end{array}$ & $\begin{array}{l}\text { Monkey } \\
\text { No. }\end{array}$ & $\begin{array}{l}\mathrm{FFU} / \mathrm{ml} \\
\text { Inhaled } \\
\quad \text { Air }\end{array}$ & $\begin{array}{l}\text { Minute } \\
\text { Respiratory } \\
\text { Volume } \\
\text { (mI) }\end{array}$ & $\begin{array}{l}\text { Estimated } \\
\text { Lung } \\
\text { Retention } \\
\text { Dose } \\
\text { (FFU) }\end{array}$ \\
\hline \multirow{3}{*}{$I$} & 1 & & 576 & $8.6 \times 10^{3}$ \\
\hline & 2 & 0.4 & 648 & $9.7 \times 103$ \\
\hline & 3 & & 576 & $8.6 \times 10^{3}$ \\
\hline \multirow{3}{*}{2} & 4 & & 662 & $4.5 \times 10^{4}$ \\
\hline & 5 & 3.0 & 605 & $4.1 \times 10^{4}$ \\
\hline & 6 & & 262 & $1.8 \times 10^{4}$ \\
\hline \multirow{3}{*}{3} & 7 & & 1152 & $1.0 \times 10^{5}$ \\
\hline & 8 & 2.4 & 662 & $6.0 \times 10^{4}$ \\
\hline & 9 & & 576 & $5.2 \times 10^{4}$ \\
\hline \multirow{3}{*}{4} & 10 & & 691 & $1.4 \times 10^{4}$ \\
\hline & 11 & 0.5 & 720 & $1.5 \times 10^{4}$ \\
\hline & 12 & & 576 & $1.2 \times 10^{4}$ \\
\hline \multirow{4}{*}{5} & 13 & & 907 & $6.8 \times 10^{4}$ \\
\hline & 14 & 2.0 & 864 & $6.7 \times 10^{4}$ \\
\hline & 15 & & 773 & $2.9 \times 10^{4}$ \\
\hline & 16 & 0.4 & 883 & $1.3 \times 10^{4}$ \\
\hline
\end{tabular}


The 2 aerosol control monkeys were exposed to an uninoculated $\mathrm{CV}-1$ cell suspension for 150 minutes. The control inoculum was prepared under identical conditions as the Yaba virus-infected $\mathrm{CV}-1$ cell suspensions.

Lung dose.--Virus retention in the lung was estimated using the following formula: tidal volume $(8 \mathrm{ml} /$ $\mathrm{kg}) \times$ respirations/minute $\mathrm{x}$ minutes of exposure $\mathrm{x} \mathrm{FFU} / \mathrm{ml}$ of air $\div 4$ (25\% retention). Utilizing a No. 14 French cuffed endotracheal tube, a $Y$ valve, and a modified Collins respirometer, multiple tidal volumes were measured in I cynomolgus and 2 rhesus monkeys following administration of phencyclidine hydrochloride. A mean tidal volume of approximately $8 \mathrm{ml} / \mathrm{kg}$ as previously determined (18) was also recorded in our studies and was used as the standard value for all of the monkeys. The minute respiratory rates were 80 for the newborn and 40-50 for all other monkeys. The 25\% figure for virus retention was estimated by correlating the particle sizes of the aerosol with data from previously reported retention studies $(19,20)$. The dose of virus retained in the lungs of an animal (No. 8) which was killed immediately following the exposure period was $2 \times 10^{4} \mathrm{FFU}$. This titer was based on the titration of 3-1.0 gm lung specimens (total lung weight: $15.75 \mathrm{gm}$ ). Clinical examination.--Physical examinations, hemograms and serologic studies were performed for at least 1 week prior to inoculation. After challenge the monkeys 
were examined daily and rectal and nasal swabs were collected at weekly intervals for virus isolation. Femoral venous blood was collected at weekly intervals for hematologic, serum protein electrophoretic, and serologic studies. The serologic studies are discussed in an accompanying report (11). The serum protein electrophoretic separation was accomplished using the Gelman electrophoresis chamber with the Sepraphore III cellulose acetate support medium. Total protein was determined by the Biuret procedure. Periodic radiographs of the thorax and skull. were taken of 5 animals. Histopathologic examination.--Surgical biopsies of subcutaneous and nasal lesions were performed on 1 monkey. The tissues were fixed in formalin, embedded in paraffin, sectioned at $6 \mathrm{u}$ and stained with hematoxylin and eosin. Euthanasia was performed at different intervals after exposure (Table 1) to study the progression of the experimental disease. A complete necropsy was performed and representative sections of all organs were fixed in $10 \%$ phosphate-buffered formalin. Selected tissues were also fixed in Carnoy's and in absolute alcohol. All tissues were embedded in paraffin, sectioned at $6 \mathrm{u}$ and stained with hematoxylin and eosin. All macroscopic lesions, multiple sections of each lobe of lung, and sections from all organs were studied microscopically. The stalns and histochemical reactions used on selected tissues included Von Kossa's, alizarin red S, Perl's, alcian blue, Wilder's 
reticulum, Gomori's trichrome, oil red 0 , periodic acidSchiff (PAS), Feulgen and methyl green-pyronine. An aerosol-exposed monkey which developed a self-limiting nasal tumor was not euthanatized but retained for additional serologic and future challenge studies.

Electron microscopy.--Sections of macroscopic lung tumors from 3 animals (No. 3, 6, and 7), a subcutaneous tumor (No. 12) and multiple sections of lung from each aerosol-exposed monkey were fixed in $1 \%$ osmium tetroxide in phosphate buffer for 1 hour. After fixation the tissues were dehydrated through ascending concentrations of ethyl alcohol, transferred to propylene oxide and embedded in Maraglas. Sections of $I \mathrm{u}$ thickness were stained with toluidine blue. Thin sections were cut at 250 to $500 \AA$ on a Porter-Blum microtome and were mounted on 200- and 400-mesh copper grids. The sections were stained with uranyl acetate and lead citrate and were examined with a Philips 200 electron microscope. The magnifications listed for the electron micrographs represent the actual magnification after printing.

Virus isolation.--Sterile cotton swabs, used for collection of weekly rectal and nasal samples, were Immersed in $3 \mathrm{ml}$ of diluent composed of medium 199 diluted 1:1 with bovine amniotic fluid. Prior to layering of the rectal and nasal samples onto confluent $C V-I$ coverslip cultures, the rectal samples were centrifuged lightly and 
the sediment discarded. Virus isolation was attempted from 24 consecutive weekly samples collected from an animal which developed a nasal tumor. From the other animals, samples were examined at weekly intervals for the first month post exposure ( $\mathrm{PE}$ ), bi-weekly for the second month, and at monthly intervals thereafter. Heparinized blood was collected periodically from monkey No. 12 and other selected animals.

At necropsy, lung tumor, normal lung tissue, tracheobronchial lymph node, and spleen were collected for virus isolation studies. The minced tissue was prepared as a 10\% w/v suspension in medium 199 diluted $1: 1$ with bovine amniotic fluid and homogenized. The homogenates were frozen and thawed 4 times, centrifuged lightly and the supernatant collected for subsequent virus isolation and titration studies on CV-I cells. When virus was not isolated in the first passage, 2 additional passages were made.

\section{Results}

Clinical disease

A monkey (No. 12) which developed self-limiting nasal and subcutaneous tumors was the only aerosol-exposed monkey with clinical signs of disease. Proof that these tumors were caused by Yaba virus was provided by light and electron microscopic studies of tumor specimens and by 
virus isolation from the nasal tumor. Serologic and rechallenge studies of this monkey are still in progress but the experimental disease during the first 6 months $\mathrm{PE}$ was considerably different from any previously attributed to Yaba virus.

A space occupying nasal tumor was first detected clinically during the sixth week $\mathrm{PE}$. Virus had been Isolated from a nasal swab at 4 weeks $\mathrm{PE}$, however, suggesting that a clinically inapparent tumor was already present at that time. The mass was located on the dorso-lateral aspect of the right nasal cavity, approximately $0.5 \mathrm{~cm}$ from the nasal orifice. As the mass progressively enlarged for the next 7 weeks (Figs. $I$ and 2) it caused distension and occlusion of the right nasal cavity, severe deviation of the nasal septum, compression of the left nasal cavity, and prominent elevation of the dorsum of the nose. There was never any evidence of tumor infiltration through the nasal septum into the left nasal cavity and no bone involvement was demonstrated radiographically (Fig. 3). At 12 weeks $\mathrm{PE}$ the elevated flattened dorsum of the nose measured 3.0 $\mathrm{cm}$ In diameter. This large mass was responsible for several secondary clinical manifestations including mouth breathing, epiphora caused by compression of the nasolacrimal duct, intermittent epistaxis, and a prominent swelling ventral and lateral to the right eye which led to complete closure of that eye for 1 week. Compared to the firm nasal 
Fig. 1. A nasal tumor in a monkey 9 weeks after aerosol exposure to Yaba virus. The right nasal cavity is distended with tumor, and the dorsum of the nose is elevated by the tumor mass. A soft, fluctuant periorbital swelling has caused partial closure of the right eye. 


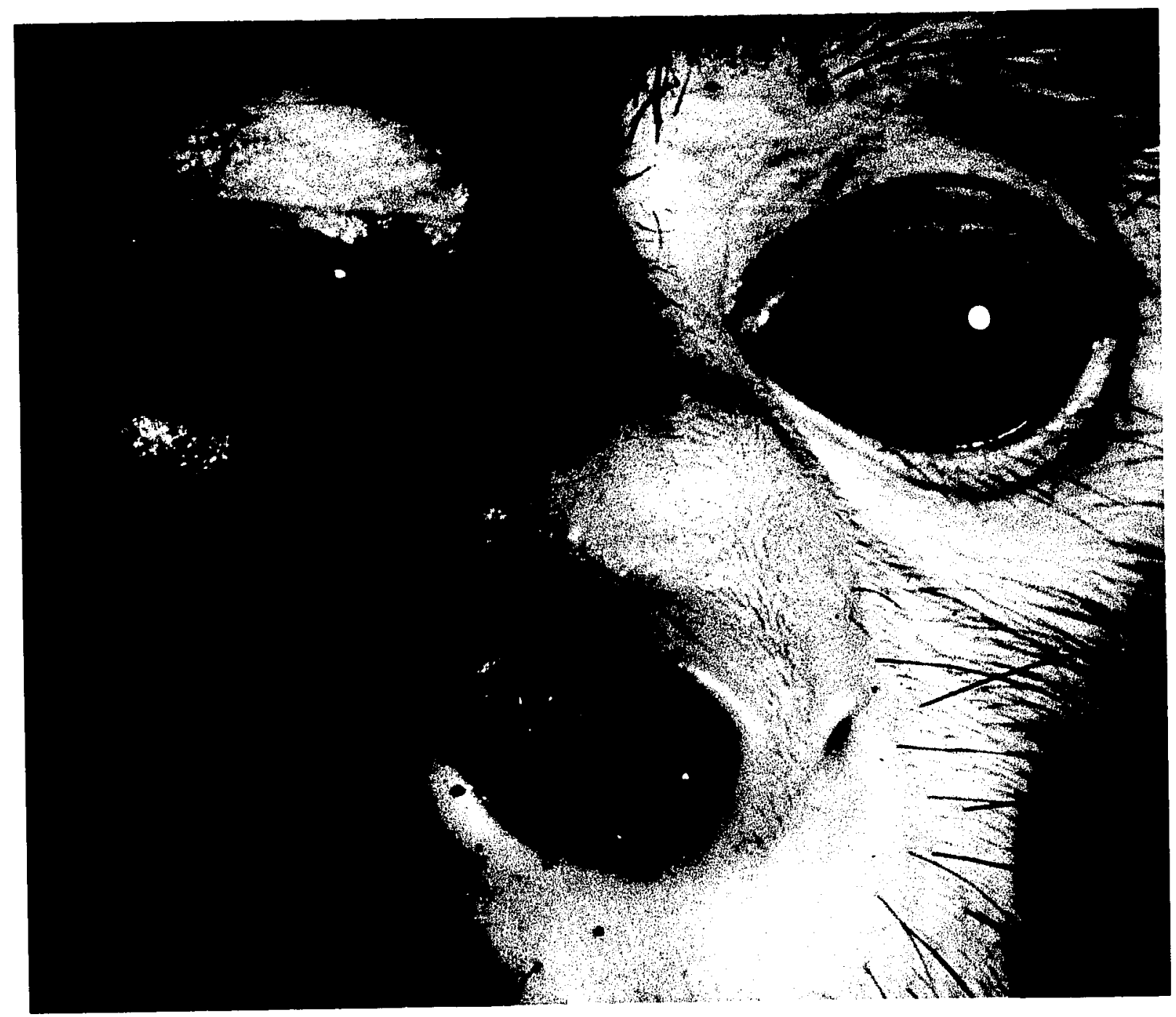

Fig. 1 
Fig. 2. The firm nasal tumor 12 weeks after exposure, representing its maximal size. The lesion on the dorsum of the nose is $3.0 \mathrm{~cm}$ in diameter. The swelling which has completely closed the right eye is still soft and fluctuant and is probably caused by interference with normal venous and lymphatic drainage. 

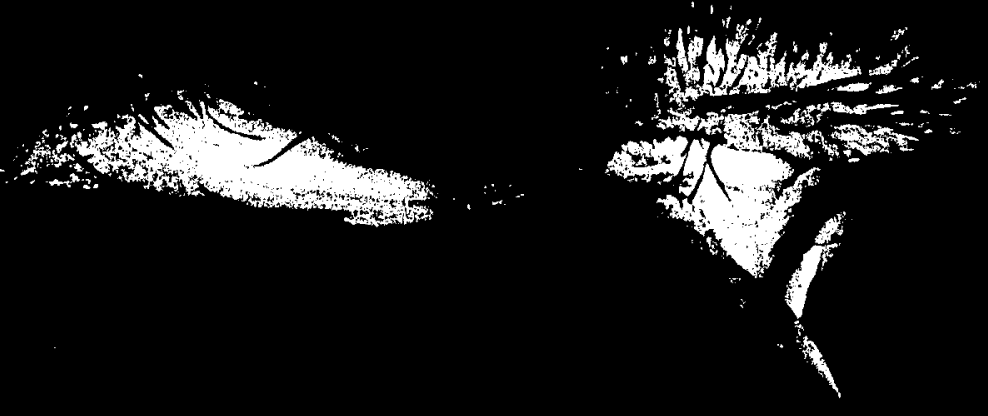

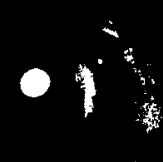

(n)

$\$$
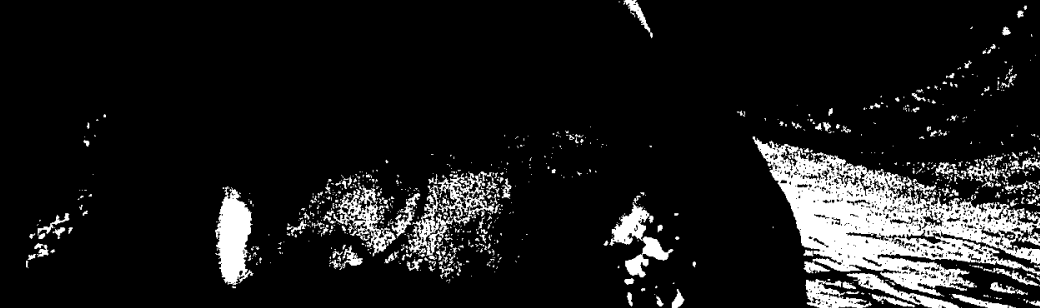

mor

$-\rightarrow+4+480$

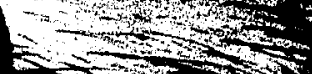

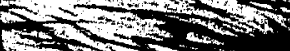

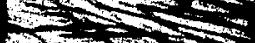
$3 \times 1=0$

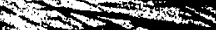

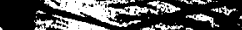
$5+20-1,0$ $1 \rightarrow \infty$
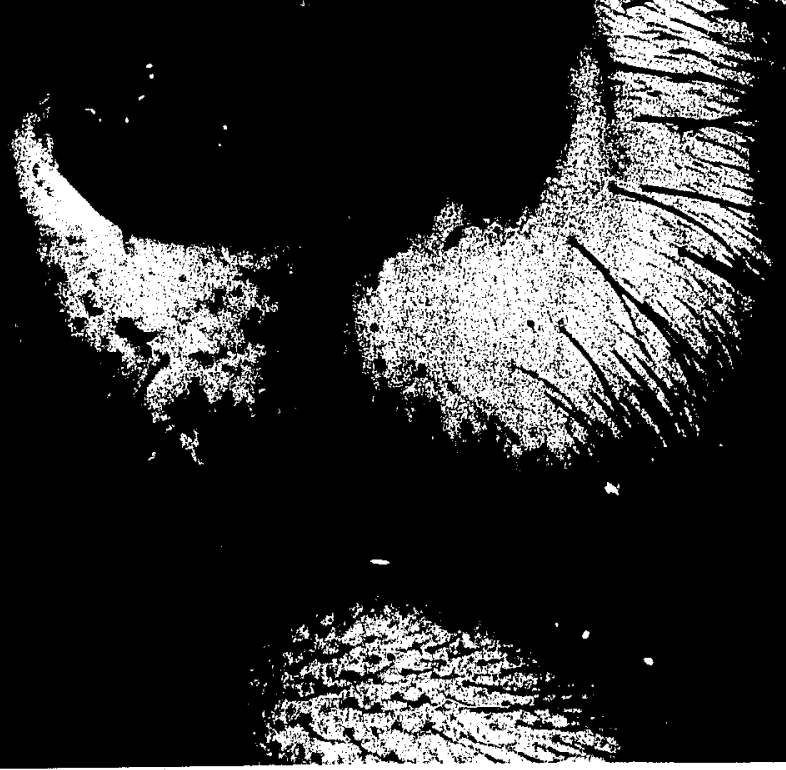

Fig. 2 
Fig. 3. Radiograph of the nasal tumor 13 weeks after exposure. The soft tissue swelling is prominent but bone is not involved. 


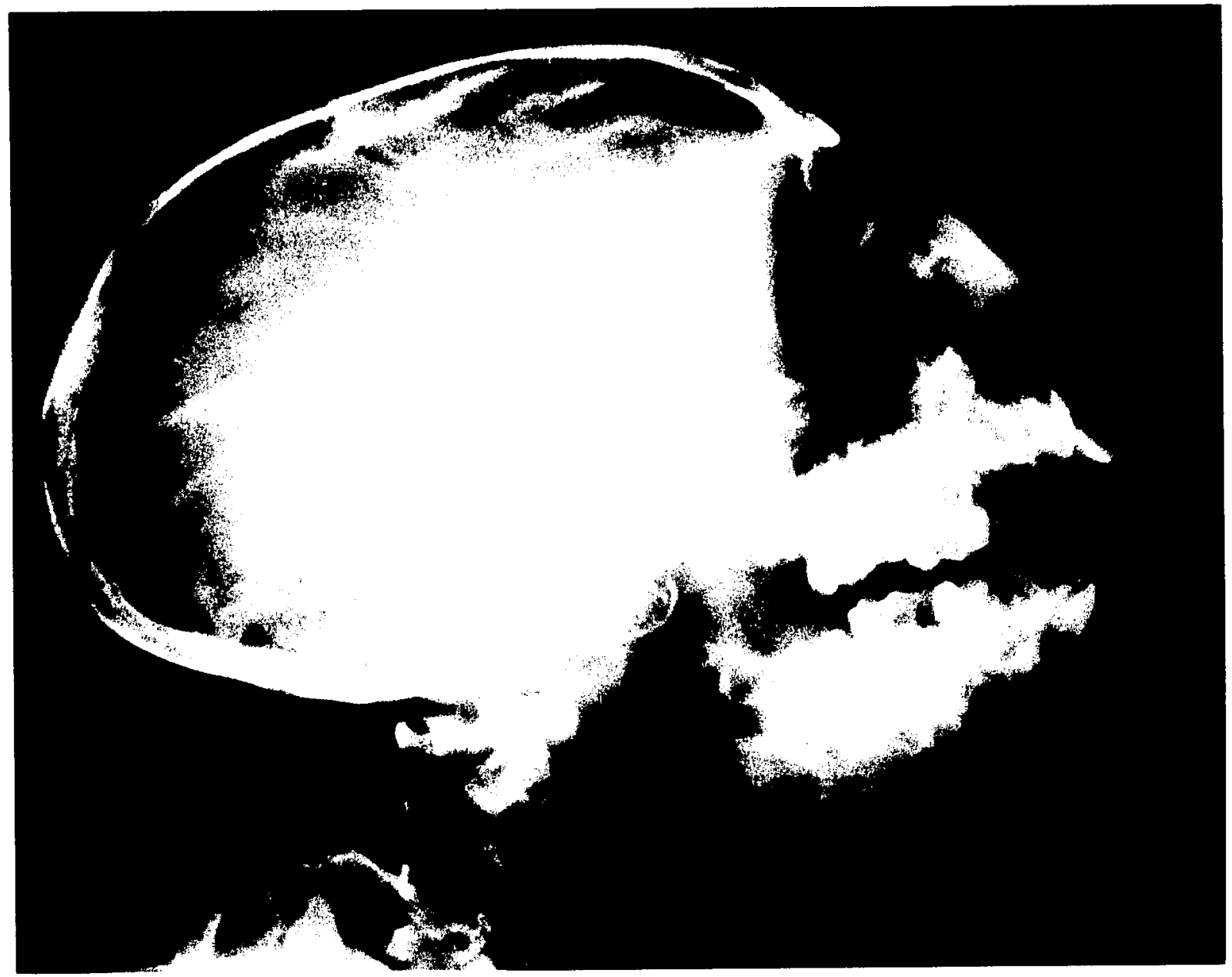

Fig. 3 
tumor the periorbital swelling was soft and fluctuant and was probably caused by interference with normal venous and lymphatic drainage. During the 12th week PE the monkey was very weak and listless. Hemoglobin and hematocrit values were $4 \mathrm{gms} / 100 \mathrm{ml}$ and $18 \%$ respectively during that week compared to baseline values of $13 \mathrm{gms}$ and $40 \%$ reflecting the severe blood loss via epistaxis. The rectal temperature remained normal throughout the observation period. A diminution in size of the nasal tumor was observed during the thirteenth $\mathrm{PE}$ week and within 7 days after the onset of regression the monkey had manually excavated the central portion of the tumor including a portion of the turbinate bone. The radical excavation created a dorsal opening into the right nasal cavity (Fig. 4) measuring $6.0 \mathrm{~mm} \times 7.0 \mathrm{~mm}$ which slightly enlarged as regression continued at the periphery of the tumor. During the sixteenth week PE a mild reactivation of the proliferative response occurred at the periphery of the original tumor but the reaction subsided within a week and regression continued. By 20 weeks $\mathrm{PE}$ the nasal tumor had completely regressed and by 24 weeks $\mathrm{PE}$ the dorsal opening into the nasal cavity was replaced by granulation tissue (Fig. 5). The thorax of this monkey was normal radiographically at 12,22 , and 24 weeks $P E$ but perihilar lymphadenopathy and an increased density in the right lung field were demonstrated in thoracic radiographs taken at 15, 17 and 19 weeks PE. These increased densities 
Fig. 4. Monkey with the nasal tumor 15 weeks after exposure illustrating a dorsal opening into the nasal cavity surrounded by residual tumor. Manual excavation of the central portion of the tumor was followed by progressive tumor regression. An ulcerated area ventral to the right eye marks the site where the periorbital swelling ruptured. 


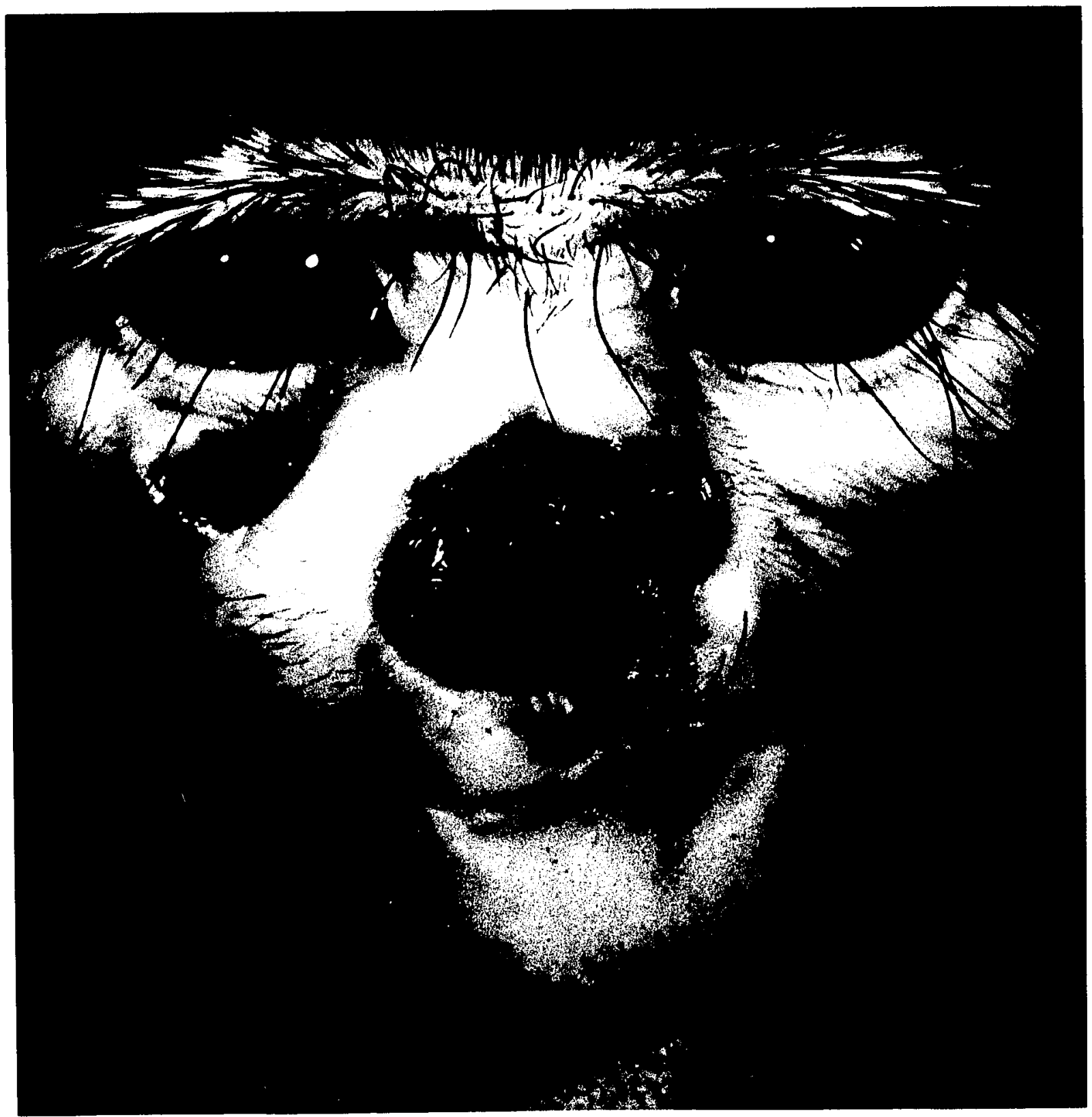

Fig. 4 . 
Fig. 5. Granulation tissue has completely obliterated the opening into the nasal cavity 24 weeks post exposure. There is a depression marking the tumor site but no residual tumor is present. 


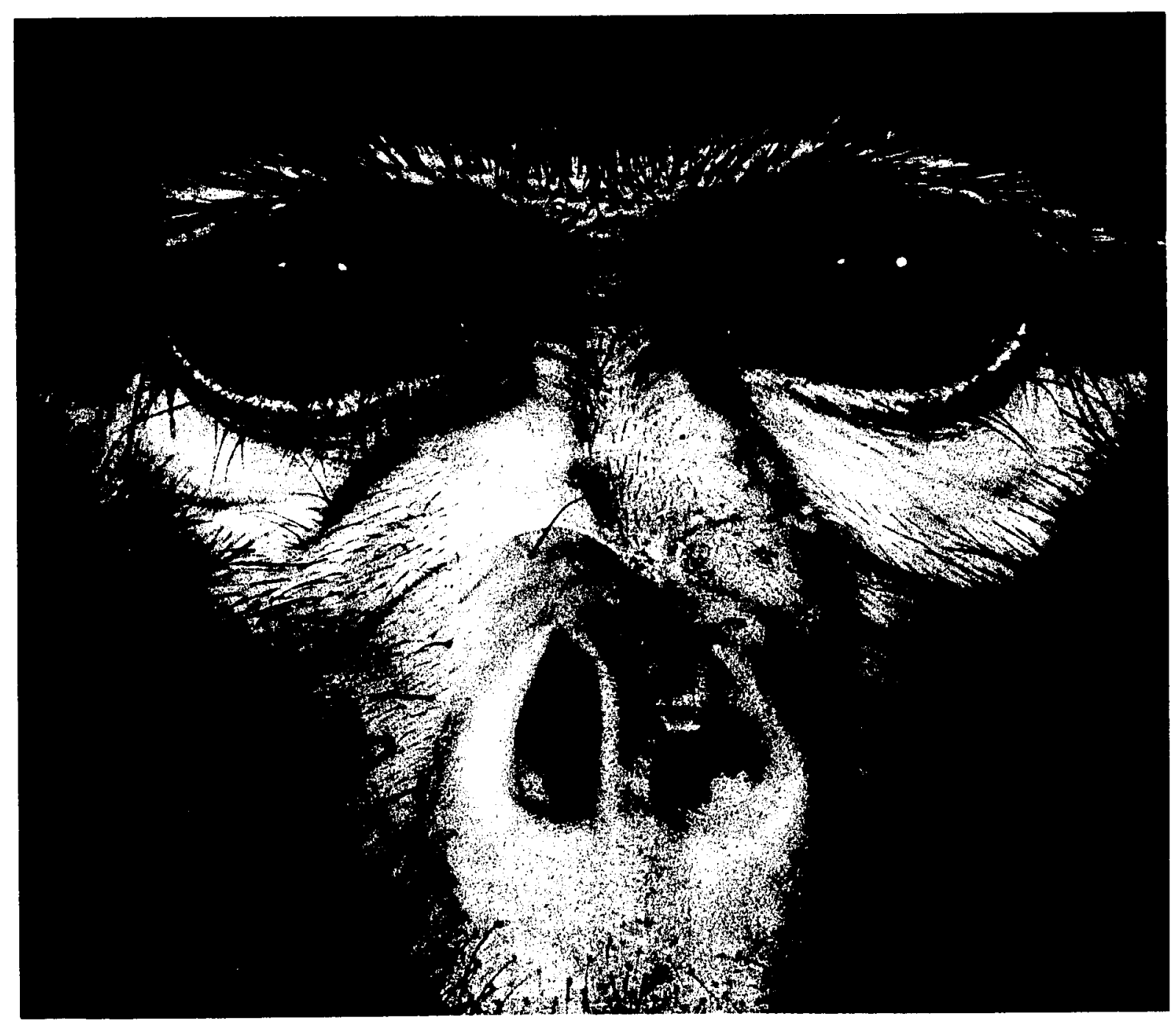

Fig. 5 
were interpreted as areas of diffuse fibrosis. ${ }^{2}$ Splenomegaly was demonstrated radiographically at 17 and 19 weeks $\mathrm{PE}$ which coincided with the period that pain was elicited during palpation of the left upper quadrant. A persistent absolute leucocytosis accompanied by a normal differential count was present 8-24 weeks PE. The mean baseline value of 8000 was elevated to a mean value of $22,000 \mathrm{cells} / \mathrm{cu} \mathrm{mm}$ for this 16 -week period. There were no significant changes in the serum electrophoretic pattern except in gamma globulin which began rising at 9 weeks $P E$, reached a peak of 2.12 gms at 17 weeks and returned to the baseline values of $0.5 \mathrm{gms}$ by the twenty-fourth week $P E$.

Several well-circumscribed subcutaneous tumors appeared sporadically during phases of proliferation, regression, and reactivation of the nasal tumor. The first 2 subcutaneous tumors were detected on the dorsal surface of the tail and on the perineum during the ninth week PE (Fig. 6). Other tumors appeared on the left foot, right foot pad, tail and right hand during the thirteenth, sixteenth and seventeenth weeks PE. The second tumor on the tail represented a recurrence of the original skin tumor that appeared concurrently with the reactivation phase of the nasal tumor. Ulceration of the subcutaneous tumors was consistently observed, perhaps predisposed by

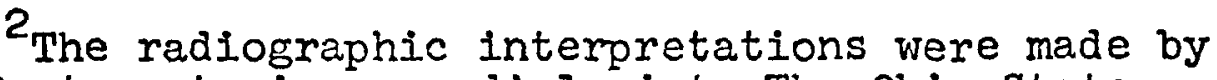
Dr. J. Burt, veterinary radiologist, The onio state University. 
F1g. 6. Well-circumscribed subcutaneous tumors on the tail and perineum (arrow) of the monkey with the nasal tumor 10 weeks after exposure. The tumors were initially detected 9 weeks post exposure, maximal size was attained at 12 weeks and they were completely regressed by 15 weeks post exposure. The surfaces of both lesions are ulcerated. 


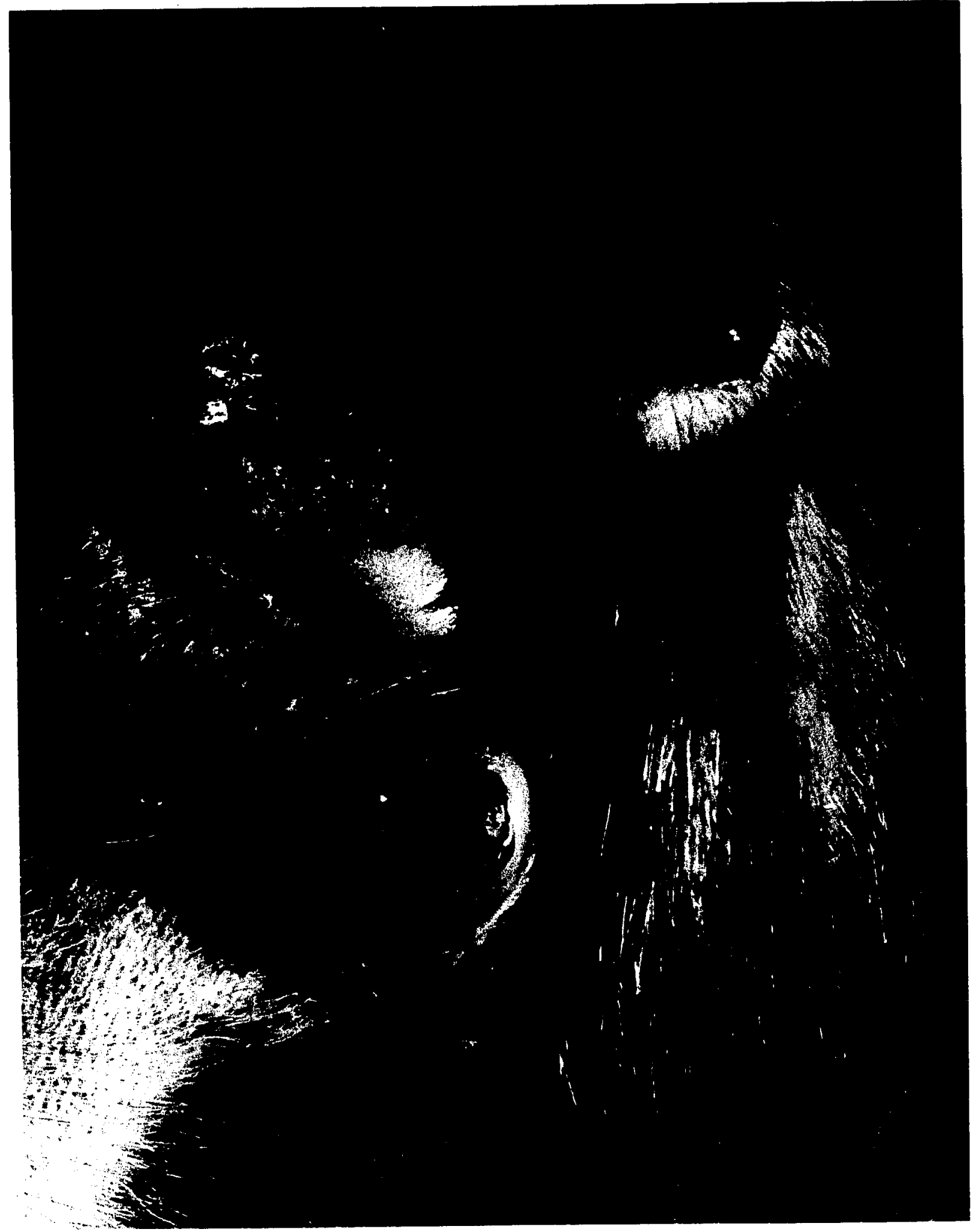

Fig. 6 
their location in readily traumatized areas. The firm masses attained a maximum size of $1.5 \mathrm{~cm}$ in diameter within 3 weeks and completely regressed within 6 weeks after detection. All of the subcutaneous tumors had completely regressed by the twenty-second week $\mathrm{PE}$.

A contact-cagemate monkey was exposed to the monkey with the nasal tumor for a 10-week period between the second and twelfth weeks $\mathrm{PE}$. The curiosity of the control animal was visibly stimulated by the appearance of the tumor at the nasal orifice and he frequently licked the exposed lesion. Clinical signs were absent in this animal during the 10-week exposure period as well as during an additional 4-week observation period prior to necropsy. Complementfixing and neutralizing anti-viral antibodies were not detected in the 14 weekly serum samples (II).

Macroscopic lesions

of 14 aerosol-exposed monkeys killed 2-16 weeks $\mathrm{PE}$, pulmonary tumors were present in 1 cynomolgus and 4 rhesus monkeys (Table 3). The well-circumscribed, spherical nodules, 0.2 to $3.0 \mathrm{~cm}$ in diameter, were located peripherally in the lobes. The largest tumors were found in the animal killed at the longest PE interval (Fig. 7). On sectioning the tumors were usually grayish-white, moderately firm and uniform in consistency (Fig. 8). A few lesions were necrotic in the center but a prominent rim of viable tumor. 
Table 3. Distribution of Yaba Virus-Induced Pulmonary Tumors in 5 Monkeys

\begin{tabular}{|c|c|c|c|c|c|c|c|}
\hline \multirow{2}{*}{$\begin{array}{l}\text { Monkey } \\
\text { No. }\end{array}$} & \multirow{2}{*}{$\begin{array}{l}\text { Euthanasia } \\
\text { (weeks PE) }\end{array}$} & \multicolumn{6}{|c|}{ Lobes of Lung } \\
\hline & & $\overline{\mathrm{IUUT}}$ & IMI & ILL & RUL & RMI & RLL \\
\hline 14 & 4 & 1 & - & - & 1 & - & 1 \\
\hline 2 & 4 & 1 & - & - & - & - & - \\
\hline 6 & 6 & - & - & - & - & 1 & - \\
\hline 3 & 8 & - & - & 2 & - & 1 & 3 \\
\hline 7 & 12 & 5 & 1 & 3 & 2 & - & - \\
\hline
\end{tabular}

LUL = left upper lobe, $I M I=$ lest middle lobe, ILL $=$ left lower lobe, RUL = right upper lobe, $\mathrm{RML}=$ right midale lobe, RLI = right lower lobe. 
Fig. 7. Medial surface of the left lung from a monkey necropsied 12 weeks after aerosol exposure illustrating multiple pulmonary tumors (arrows). The large tumor, $3.0 \mathrm{~cm}$ in diameter, is in the lower lobe. 


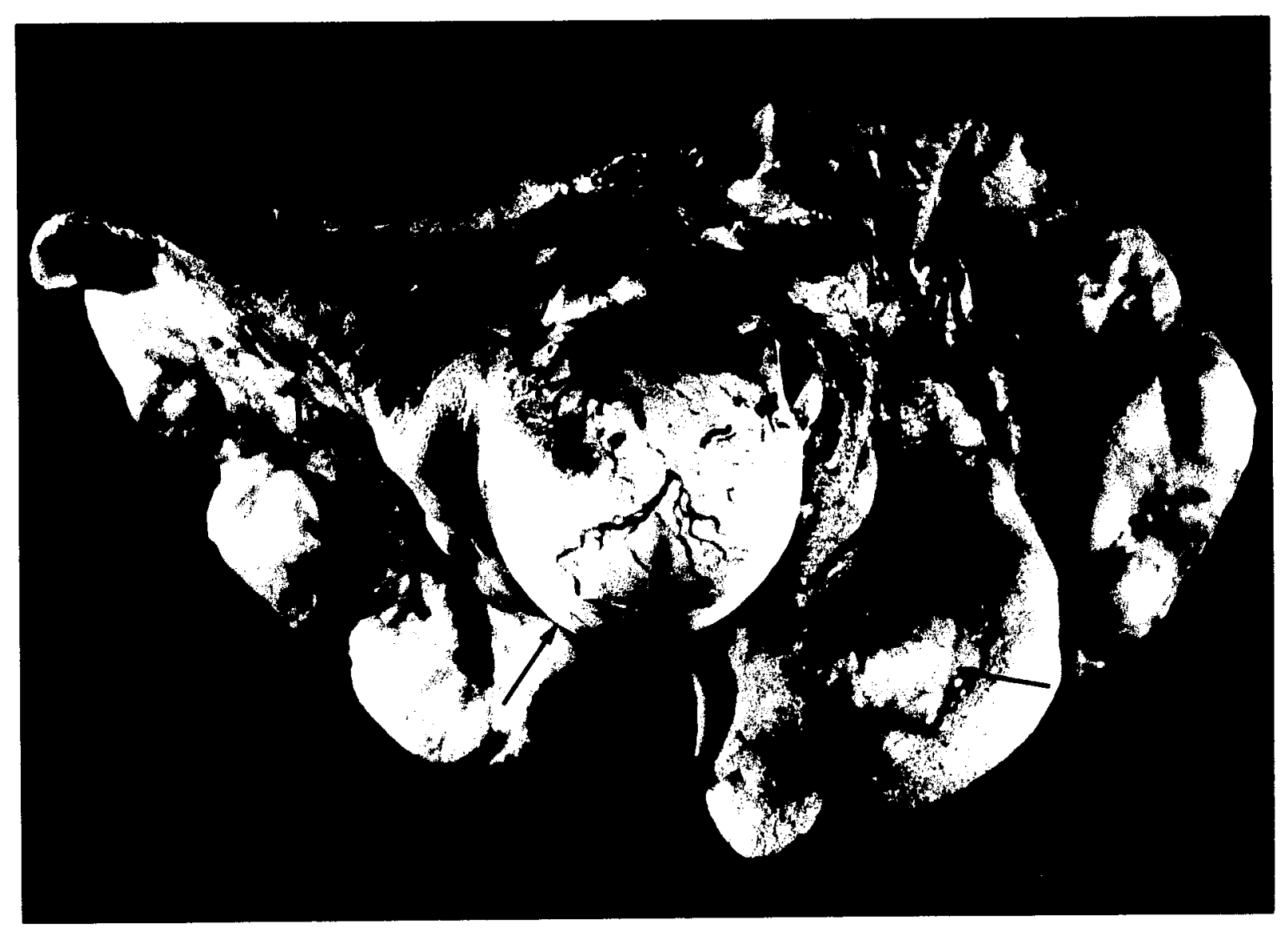

Fig. 7 
Fig. 8. The large tumor in Figure 7 sectioned transversely. The tumor is uniform in consistency with scattered dark areas of hemorrhage and no evidence of necrosis. Compressed lung parenchyma (arrows) is prominent at the periphery of the mass. 
33

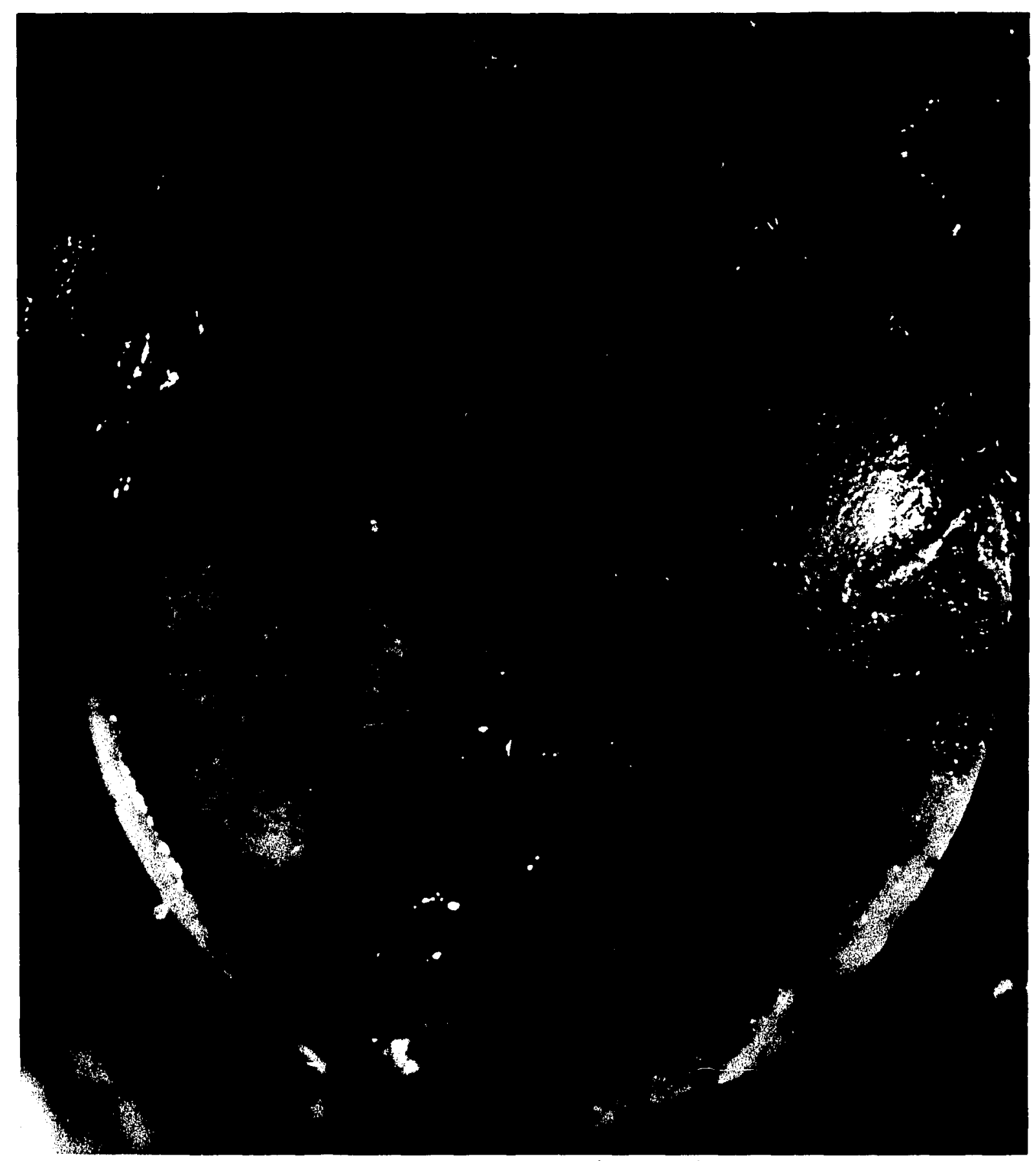

Fig. 8 
tissue always surrounded the necrotic debris or empty space (Fig. 9). Severe peripheral compression of the lung parenchyma was evident around the larger tumors creating a delusion of encapsulation. Virus-induced lesions were not found in other organs.

Parasitic lesions were responsible for all incidental macroscopic findings. Yellowish-gray, discrete subpleural nodules, $2.0 \mathrm{~mm}$ in diameter, were seen in 4 rhesus monkeys. They were compatible with the lesions caused by the lung mite, Pneumonyssus simicola. Oesophagostomum lesions characterized by reddish-brown submucosal nodules, $2.0 \mathrm{~mm}$ in diameter, were present in the colon of 3 rhesus monkeys. Parasitic lesions were absent in the laboratory-reared monkeys.

Yaba virus-induced lesions were absent in the 2 aerosol-control monkeys and in all 3 contact-exposure monkeys.

Microscopic lesions

Microscopic Iesions attributable to Yaba virus were confined to the 6 monkeys with macroscopic lesions and except for the subcutaneous tumors in 1 monkey, the lesions were restricted to the respiratory system. In the animals with early pulmonary lesions (No. 2, 6, and 14), alveolar septa (Fig. 10) represented the sites of the initial proliferative response. The septa were increased in 
Fig. 9. Central necrosis in a lung tumor from an animaI necropsied 8 weeks after aerosol exposure to Yaba virus. This mass which elevated the overlying pleural surface was composed of a central fluid-filied cavity surrounded by a rim of tumor tissue. Tumors with central necrosis were seen infrequently compared to solid tumors (Figure 8). The scaje is in millimeters. 
the

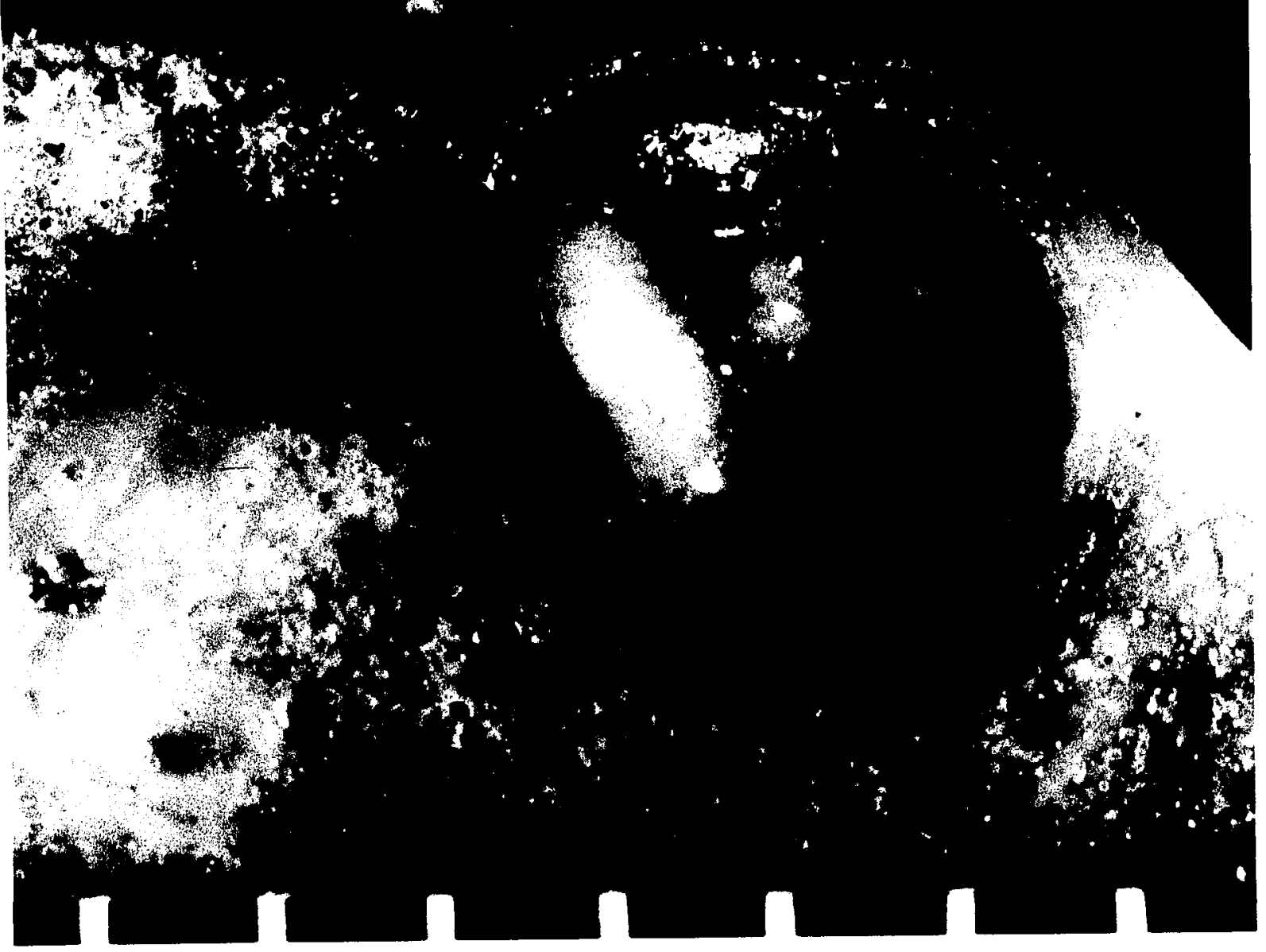

Fig.9 
Fig. 10. Photonicrograph of Iung from a monkey necropsied 4 weeks after aerosol exposure to Yaba virus. Thickened alveolar septa (A) represented the earliest morphologic response to Yaba virus. Mild proliferation of alveolar epithelial lining cells is evident (arrow). An occasional giant cell (GC) was seen in the early lesions. 
38

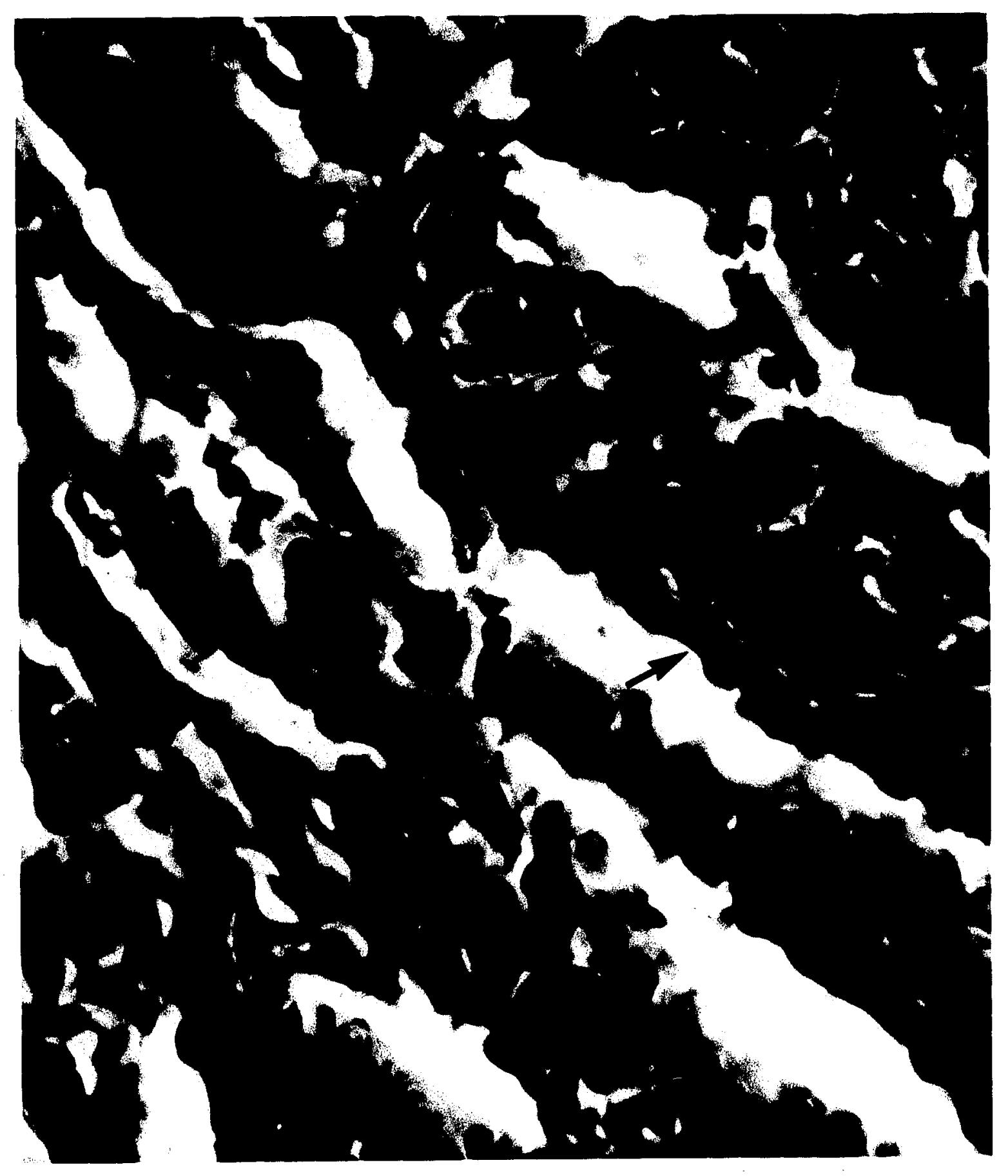

Fig. 10 
thickness by focal hypercellularity of the interstitial tissue with mild concomitant proliferation of the alveolar lining cells. The tumor cells were predominantly polygonalshaped with resicular, sometimes indented, nuclel and abundant cytoplasm. Spindle-shaped cells were sparsely distributed throughout the lesions and multinucleated giant cells were observed occasionally. Small intracytoplasmic inclusion bodies were seen in widely scattered cells and approximately I mitotic figure/5000 cells was observed. A few eosinophils were scattered within and peripheral to the lesions. Later in the course of the disease as represented in 2 animals (No. 3 and 7) the focal lesions were much larger and were composed of a uniform cell population with close cellular apposition (Fig. II). Instead of the alveolar septa being prominent components of the advanced lesions they were only represented by thin strands of vascular connective tissue stroma which separated the cells into groups. Compared to eariy lesions the polygonal cells were larger and approximately $50 \mathrm{u}$ in diameter. The nuclei were eccentrically displaced, the nucleoll enlarged and prominent and the cytoplasm more abundant and vacuolated with more lipid droplets. Single or multiple irregularlyshaped intracytoplasmic inclusion bodies were present in over $50 \%$ of the cells (Fig. 12). The large inclusion bodies were acidophilic or slightly basophilic with hematoxylin and eosin and were Feulgen-, methyl green- and 
Fig. 11. A well-demarcated, densely cellular tumor froman animal necropsied 12 weeks after exposure. It is composed of a uniform cell population that is separated into groups of cells by thin strands of vascular connective tissue stroma (arrows). The tumor mass is surrounded by compressed lung parenchyma (I) which is infiltrated with mononuclear cells. $H$ and $E, x 125$. 


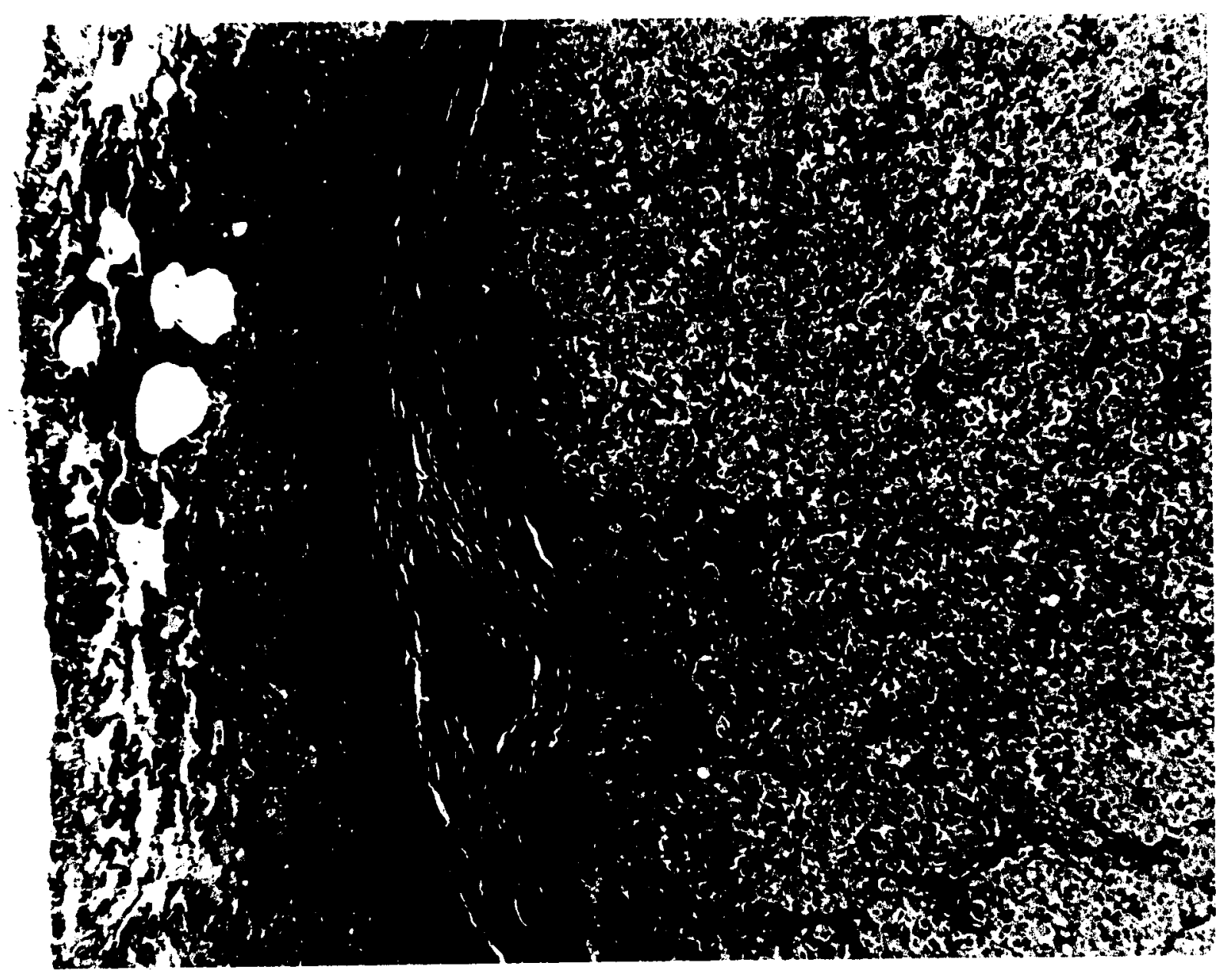

Fig. 11 
Fig. 12. Iarge vacuolated polygonal cells comprising the tumor mass in Figure 10. Intracytoplasmic inclusion bodies (arrows) are prominent in many cells and the nucleoli are enlarged. $\mathrm{H}$ and $\mathrm{E}, \mathrm{x} 315$. 


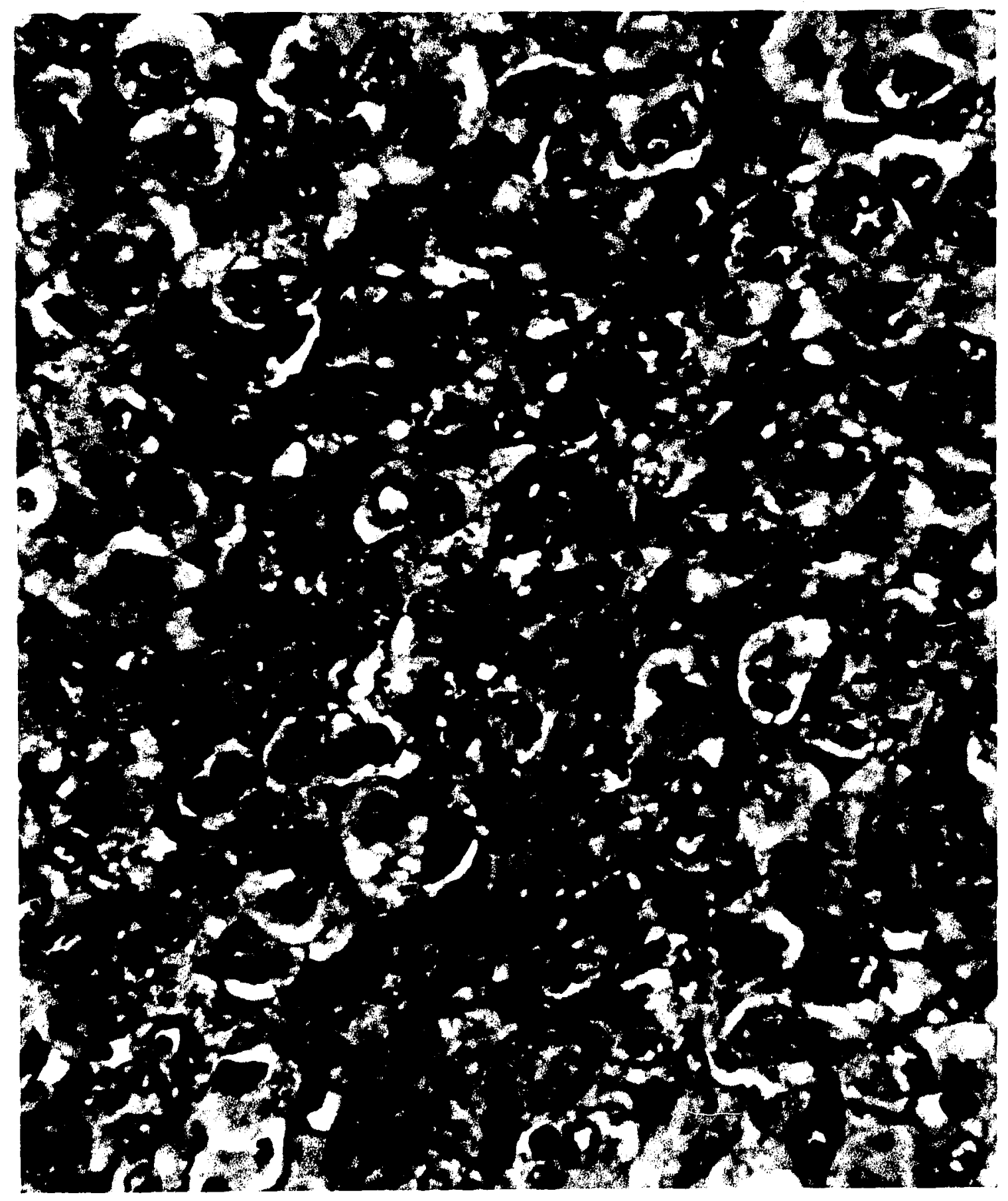

Fig.12 
pyronine-positive and PAS- and alcian blue-negative. Mitotic figures, if present at all, were only seen at the periphery of the lesions. No eosinophils or mononuclear cells were present within the lesions but a few neutrophils were distributed along the stromal network. Necrosis of tumor cells was prominent in the centers of a few nodules but necrosis was minimal in the 2 large masses, $3 \mathrm{~cm}$ in diameter, that were present in the animal sacrificed at the longest $\mathrm{PE}$ interval (No. 7).

The peripheral expansion of the proliferative lesions severely disrupted the normal lung architecture. Encapsulation was often simulated by compressed lung parenchyma at the periphery of the lesions. Compression of bronchi and bronchioles, invasion of bronchioles and blood vessels, and endothelial cell proliferation with subsequent occlusion of venules and arterioles were observed at the periphery of the advanced lesions. In some instances It was difficult to determine whether vascular occlusion was secondary to an endothelial cell response or to tumor invasion. In the animal sacrificed at 6 weeks PE (No. 6) peribronchial lymphatics as much as $1.0 \mathrm{~cm}$ from the peripherally located tumor were filled with cells morphologically identical to the proliferating septal cells (Fig. 13).

A cellular reaction composed of lymphocytes, histiocytes, plasma cells and eosinophils was regularly 
Fig. 13. A peribronchial lymphatic (arrow) filled with tumor celis in a monkey necropsied 6 weeks after exposure. This lymphatic was approximately $1.0 \mathrm{~cm}$ from a tumor nodule. $\mathrm{H}$ and $\mathrm{E}, \mathrm{x} 125$. 


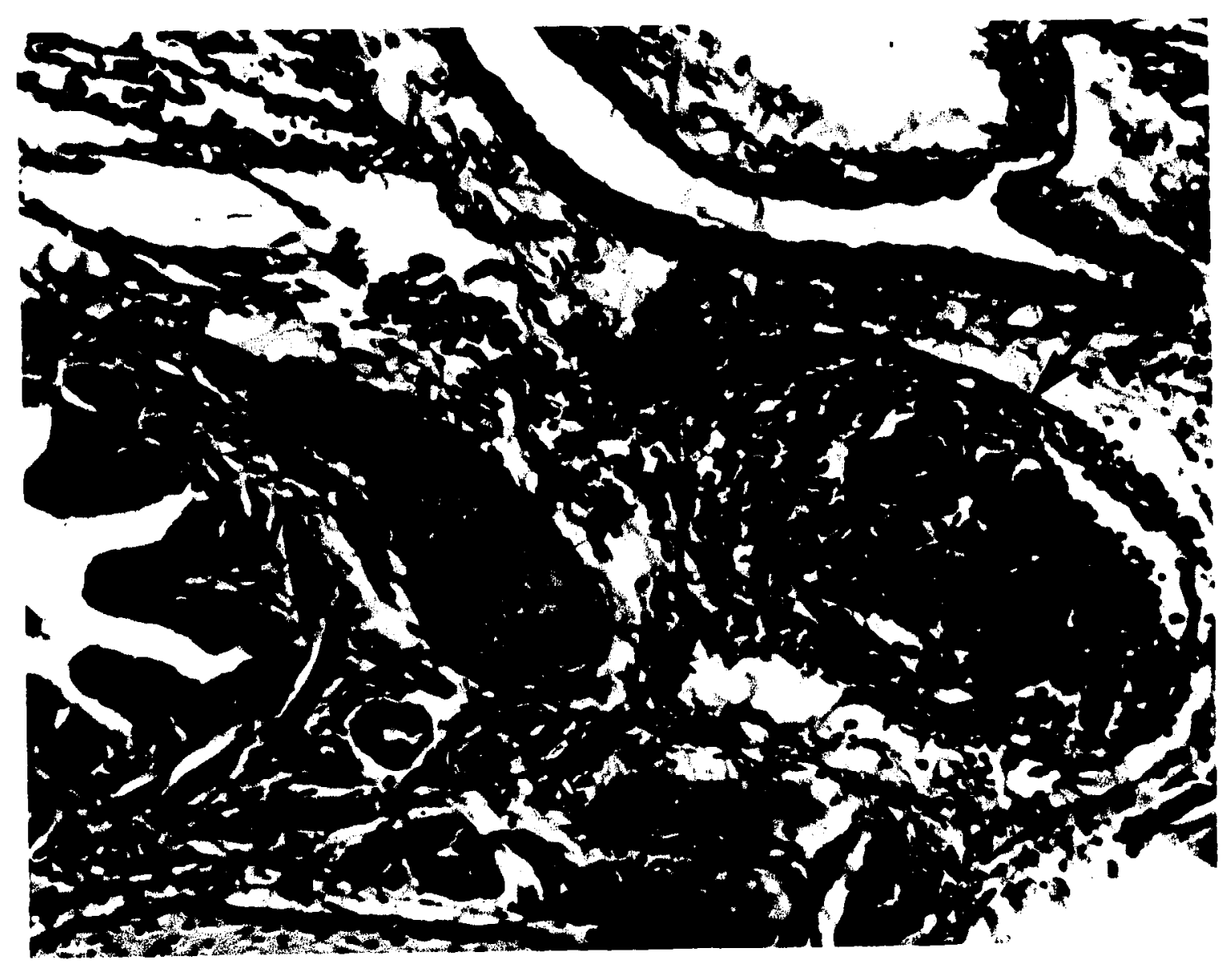

Fig. 13 
present at the periphery of the Yaba virus-induced lesions. This reaction was particularly prominent in perivascular tissues and in the peripherally-compressed lung parenchyma. The predominant cell and intensity of the reaction were variable, and there was no apparent correlation between the quality and quantity of this reaction and the size of the proliferative lesions or presence of cell necrosis.

Pulmonary acariasis and adrenal mineralization were the major incidental findings. Pulmonary acariasis (21,22) characterized by bronchiolitis, peribronchiolitis, and widely disseminated mite pigment throughout the lung and hilar lymph nodes was present in $100 \%$ of the imported rhesus monkeys but was not seen in imported cynomolgus and laboratory-reared monkeys. There was no evidence that these previously damaged areas in the lung served as predilection sites for the Yaba virus-induced lesions. Bilateral adrenal mineralization was present in 13 of 16 rhesus monkeys but absent in the 5 cynomolgus monkeys. The spherical mineral deposits were restricted to the cortico-medullary junction and the zona reticularis. These lesions were identical to those described previously by Ross et al. (23) in 27 of 54 rhesus monkeys. Other incidental findings which were found In 3 rhesus monkeys included focal granulomatous colitis (oesophagostomiasis) and non-suppurative nephritis, slaladenitis, and myocarditis. 
In 1 monkey (No. 12) the clinical diagnosis of Yaba virus-induced nasal and subcutaneous tumors was confirmed histopathologically. The nasal tumor, morphologically similar to Yaba virus-induced subcutaneous tumors $(4,9)$, was composed primarily of large polygonal cells with large vesicular nuclei and abundant cytoplasm. Intracytoplasmic, Feulgen-positive inclusion bodies were observed in scattered cells. No eosinophils or mononuclear cells were seen within the tumor mass but a cellular reaction present at the periphery of the nasal lesion was identical to the reaction which surrounded the lung tumors. At 24 weeks $P E$ no residual tumor cells were detected in a biopsy specimen collected from the original tunor site.

Lesions attributable to Yaba virus were absent in the germfree monkey exposed to Yaba virus at 12 months of age. This animal had been exposed to a larger dose of virus than several conventional monkeys which developed tumors. The histologic appearance of the Iymphoid tissues, Iung and intestine were compatible with that of other germfree animals. Focal bilateral adrenal mineralization and focal lymphocytic infiltrates in I kidney were the only lesions observed in this animal. Normal testicular development was noted.

Electron microscopy

The lung tumors from 2 animals (No. 3 and 7) were similar ultrastructurally and were composed of large 
polygonal cells admixed with sparsely distributed spindleshaped cells. Intracytoplasmic viral particles morphologically identical to previously described Yaba virus (2428) were present in both cell types. The nuclei of the polygonal tumor cells were oval or round and often eccentrically placed. The nucleoli were enlarged but their fine structure appeared normal. In the cytoplasm (Fig. 14) there were oval to round mitochondria, variable amounts of granular endoplasmic reticulum, prominent Golgi complexes and free ribosomes. Aggregates of smooth membranes were frequently seen in the cytoplasm, usually adjacent to areas of viral synthesis. Cylindrical structures often emanated from the periphery of these aggregates. Some cells were covered with surface microvilli and contained large electrondense multilamellar bodies (Fig. 15) compatible with the cytosomes of granular pneumonocytes (29-33). Small Irregularly-shaped, membrane-limited lysosomes of variable electron density were also observed, usually in cells surrounded by smooth plasma membranes. Membrane-bound droplets of lipid were commonly seen in the cytoplasm of cells containing a high concentration of virus. Membranous honeycombed structures (Fig. 16) which have been described in other poxvirus infections $(34,35)$ were seen infrequently. They were located adjacent to the areas of viral synthesis and were composed of pentagonal or hexagonal units in which a central translucent area was surrounded by an electron-dense wall. 
Fig. 14. Electron micrograph of a tumor cell from the lung of an aerosol-exposed monkey. Mature viral particles are distributed throughout the cytoplasm (arrows). Prominent Golgi complexes (G), distended cisternae of endoplasmic reticulum (ER), ribosomes (R) and an aggregate of smooth membranes (S) are present in the cytoplasm. $N=$ nucleus, $\mathrm{Nc}=$ nucleolus, $\mathrm{M}=$ mitochondria, $\mathrm{PM}=$ plasma membrane. $x 23,250$. 


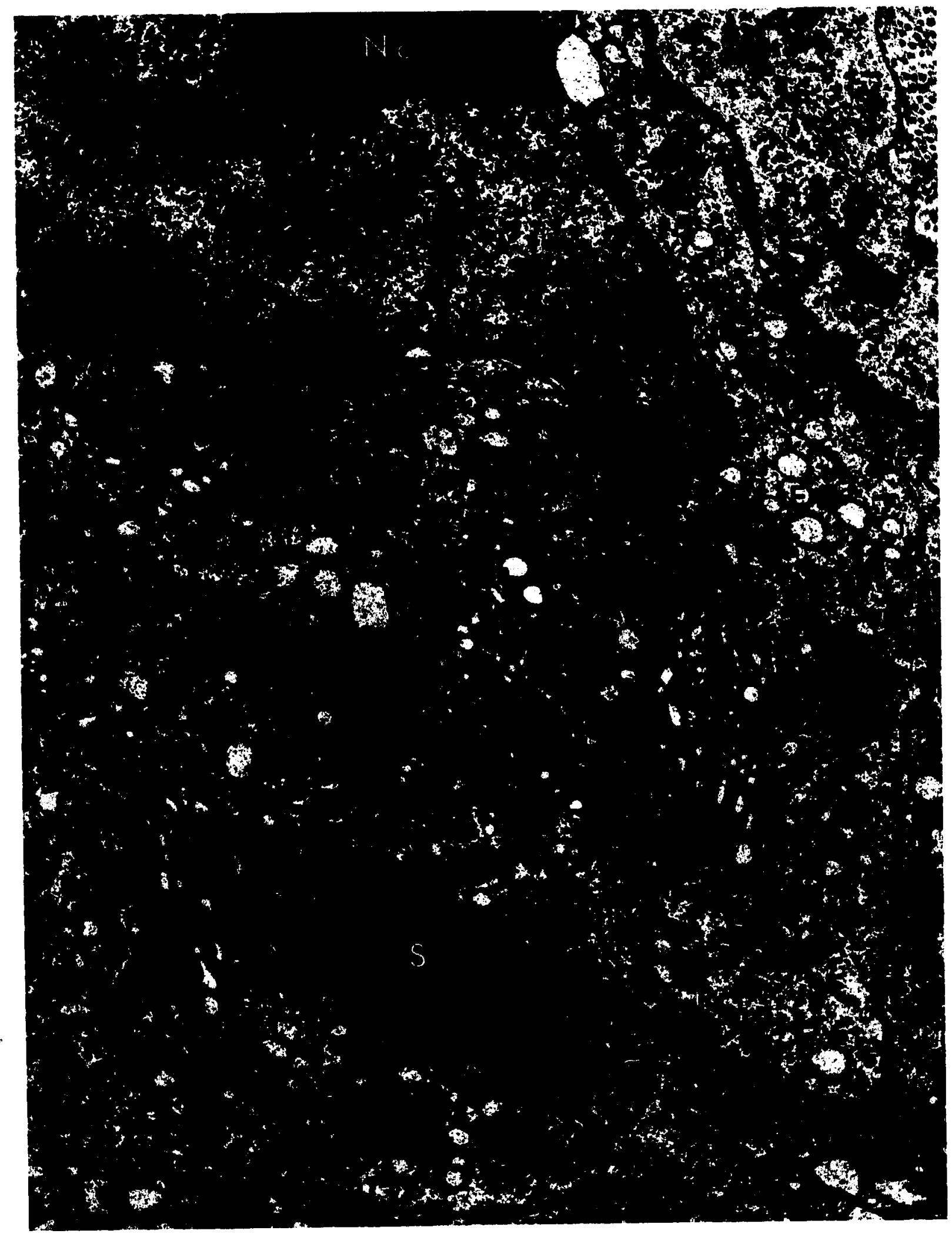

Fig. 14 
Fig. 15. Multilamellar bodies (MB) adjacent to a site of viral synthesis in the cytoplasm of a granular pneumonocyte. Cylinders (CY), electron-dense aggregates (A) and viral particles (arrows) are prominent within the area of viral synthesis. The surface of this cell was covered with microvilli. X 36,000. 


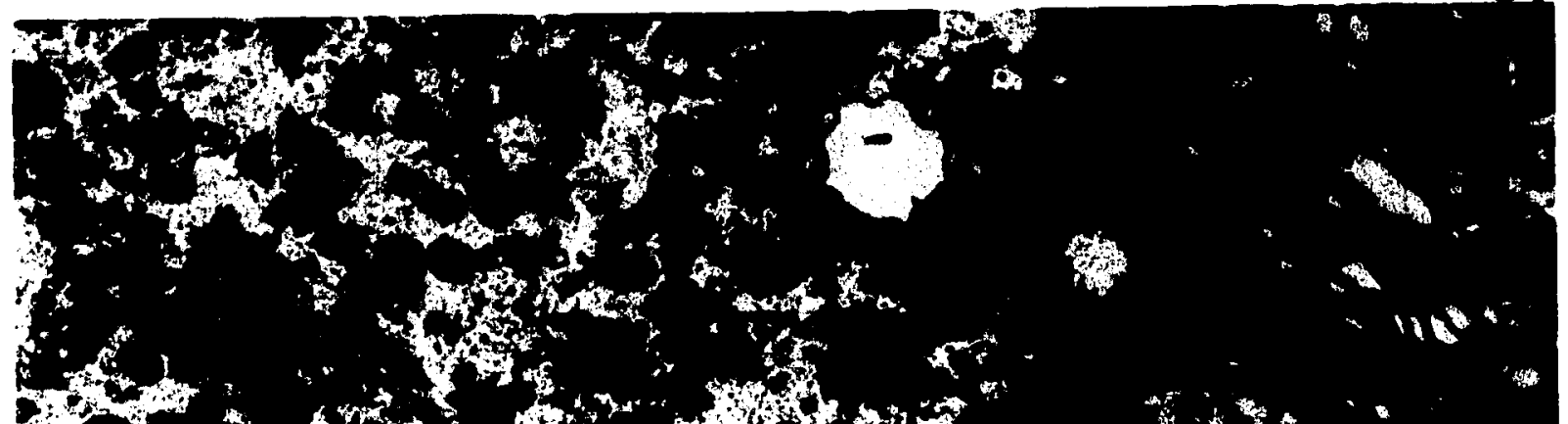

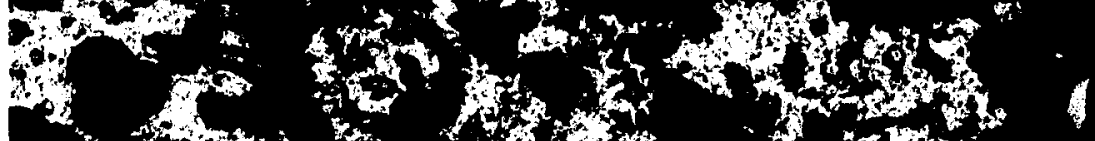

4

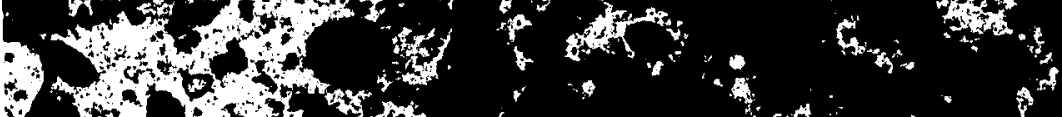

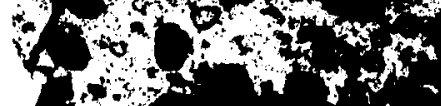
$t^{2}+2 x+2$

40

20.

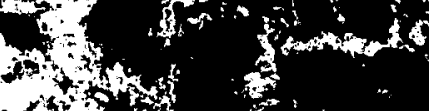

$\rightarrow x^{2}+x^{2}$

3 tot

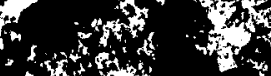

$+4$

ots

$4 x^{3}+4+4$

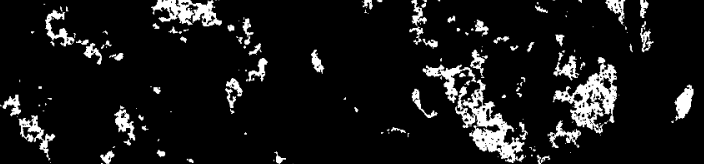

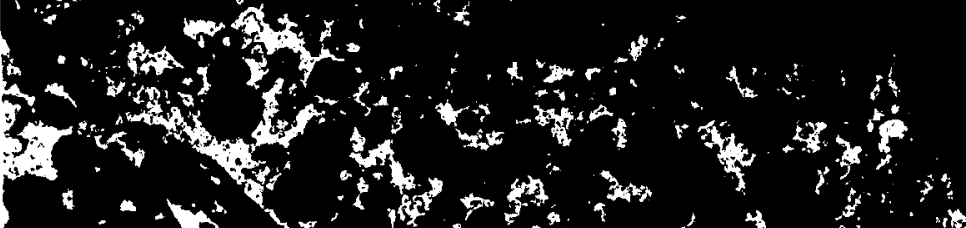

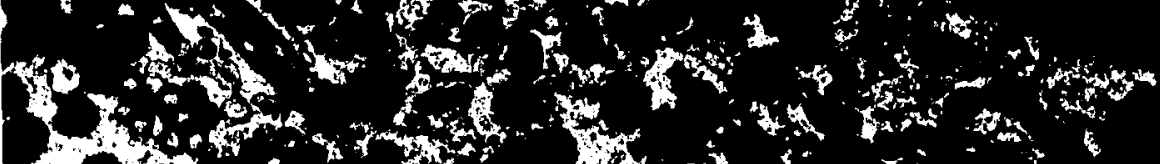

$10 x$ tor

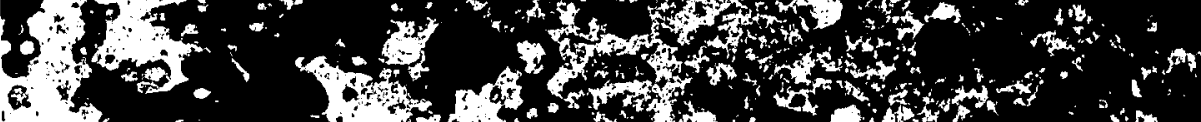

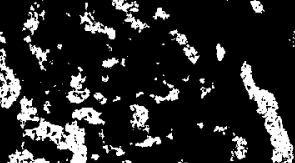

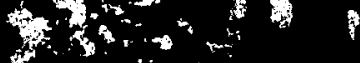

F

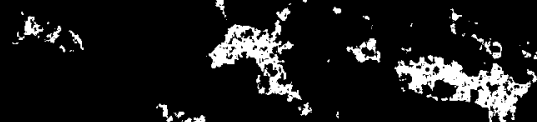

$+3$

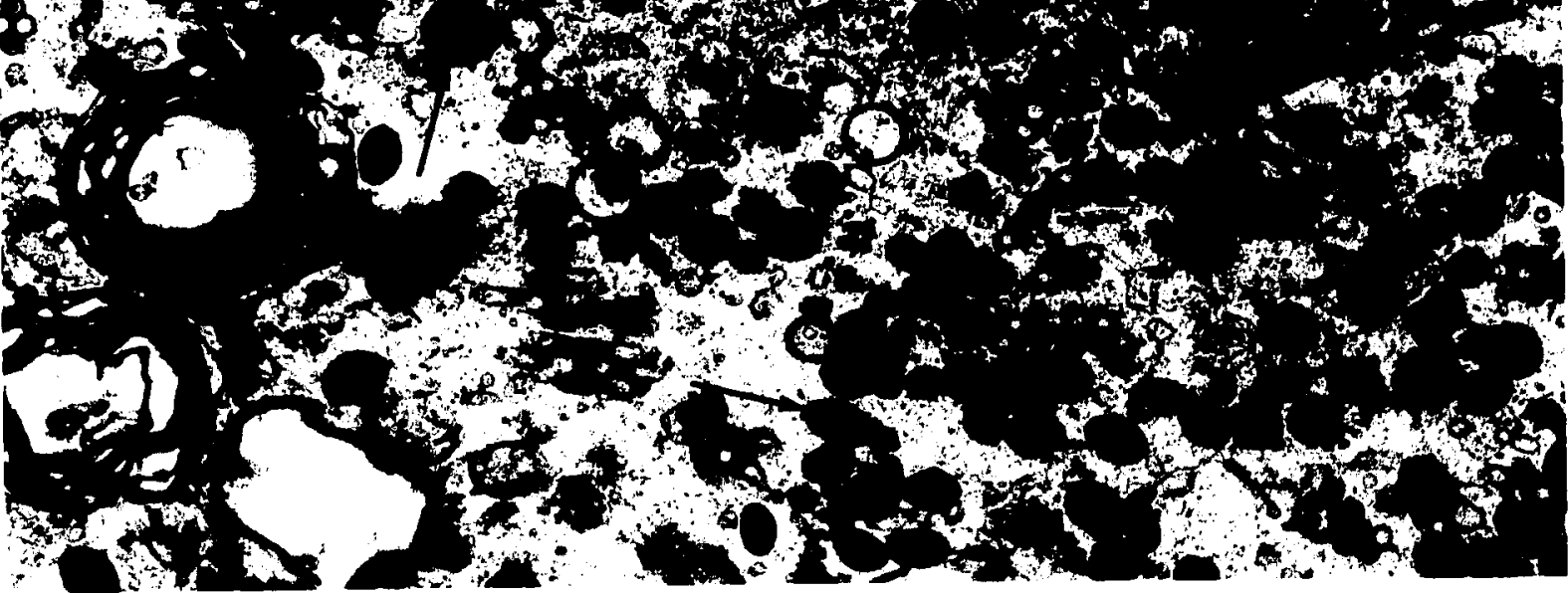

Fig.15 
Fig. 16. Membranous honeycombed structures (H) adjacent to a site of viral synthesis in a tumor cell. Ribosomes (R), electron-dense aggregate (A) and viral particles (arrows). X 39,500. 


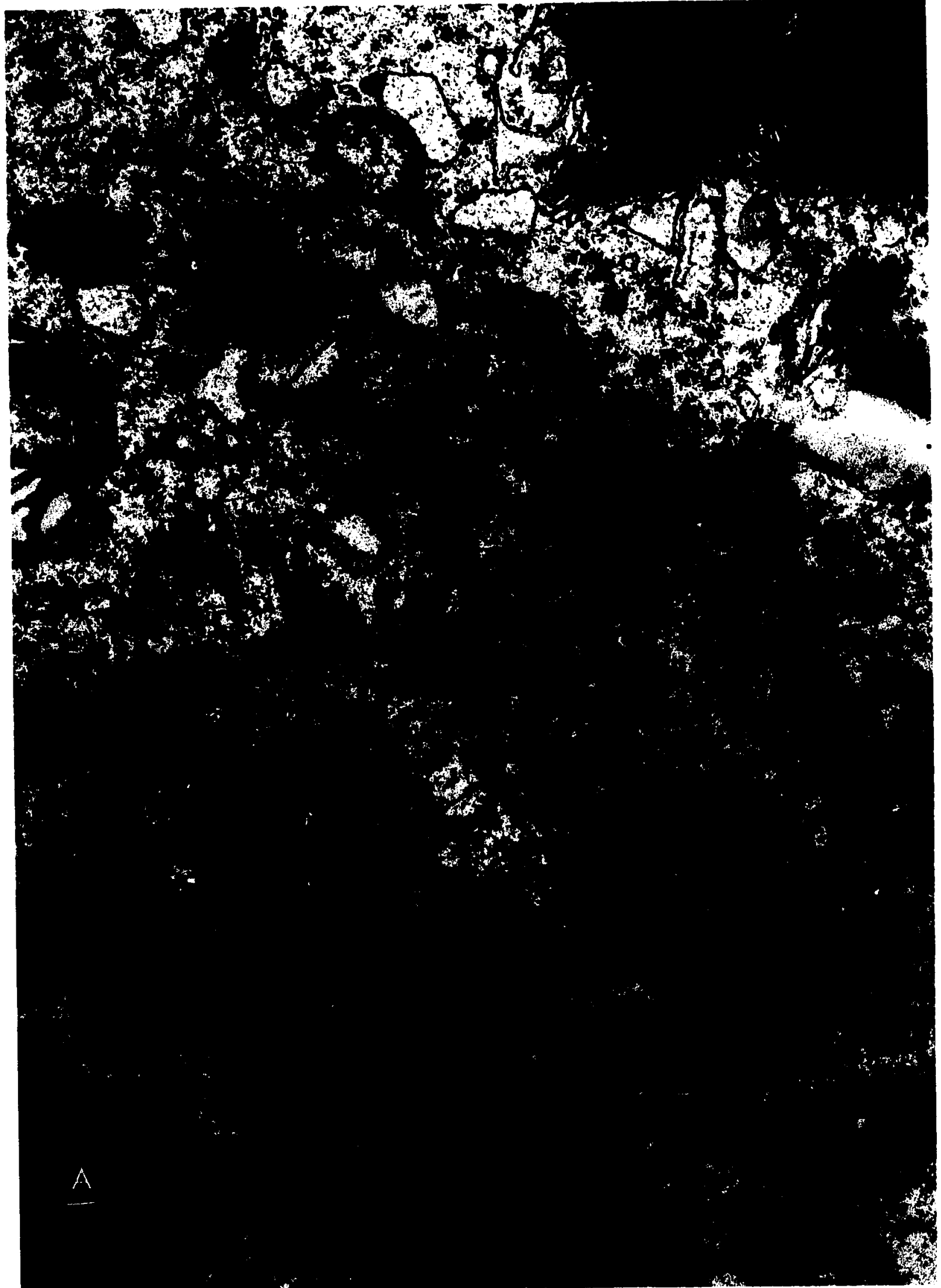

Fig.16 
Virus replication was observed in the cytoplasm of many tumor cells. The single or multifocal well-demarcated sites of viral synthesis were devoid of normal cytoplasmic organelles but no limiting membrane was present (Fig. 17). Granular endoplasmic reticulum was usually prominent immediately adjacent to these areas of viral synthesis. Formation of an immature virus particle was initiated by sequestration of viroplasm in short curved membranes (crescents) covered with radially-oriented spines or subunits (Fig. 18). These immature particles developed sequentlally (24) into mature, electron-dense, elongated particles within inclusion bodies (Fig. 19). The mature particles measured approximately $350 \mathrm{mu}$ in length by 150-200 mu in thickness. Long cylinders (Fig. 15) were usually seen within the areas of viral synthesis and subunits similar to those covering the Immature particles were present on the surface of some but not all. of these cylinders. Iong filaments (36) were also observed occasionally within the inclusion bodies. As maturation proceeded within the areas of viral synthesis, the change from developmental forms to mature virus was accompanied by a more diffuse distribution of viral particles in the cytoplasm. Extracellular particles, both mature and immature, were observed occasionally in areas where the cells were severely distended with virus. Virusfree cells, however, were often seen immediately adjacent 
Fig. 17. A well-demarcated area within a tumor cell in the lung, representing an early site of viral synthesis. It is nearly devoid of cytoplasmic organelles but contains electron-dense particulate aggregates (A). Smooth membranous structures (S), Golgi complexes (G), granular endoplasmic reticulum (ER) and mitochondria (M) are seen in the cytoplasm surrounding the area of viral synthesis. $X 36,900$. 


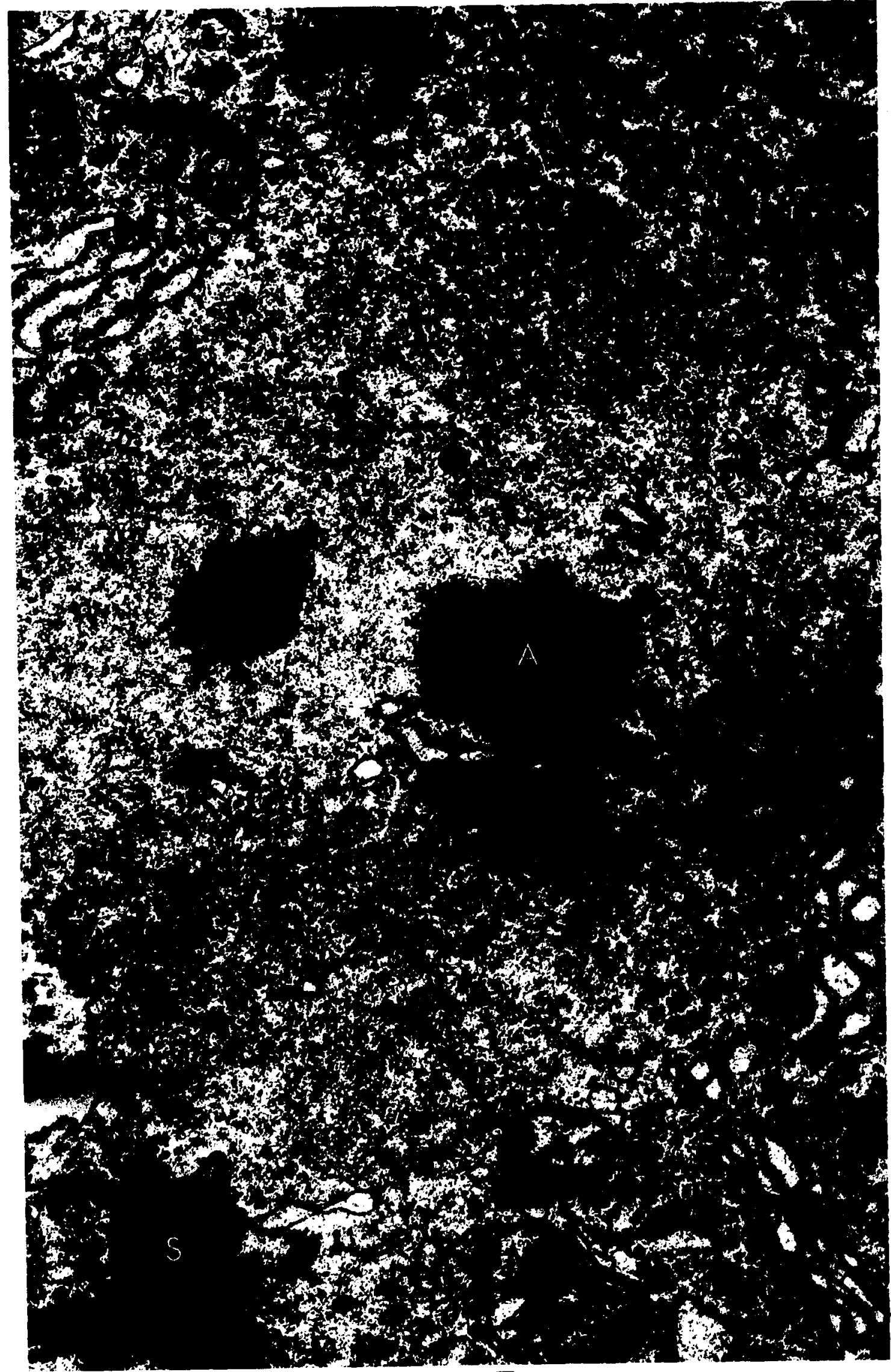

Fig.17 
Fig. 18. An intracytoplasmic site of viral synthesis in a cell from a Yaba virus-induced lung tumor. Sections of cylinders (CY) and immature viral particles (arrows) are surrounded by a unit-membrane coated with radially-oriented subunits or spines. One aggregate (A) is composed of particulate subunits very similar to those covering the immature particles. A type I viral particle or "crescent" (C) appears to be sequestering viroplasm. $\mathrm{X} 57,500$. 


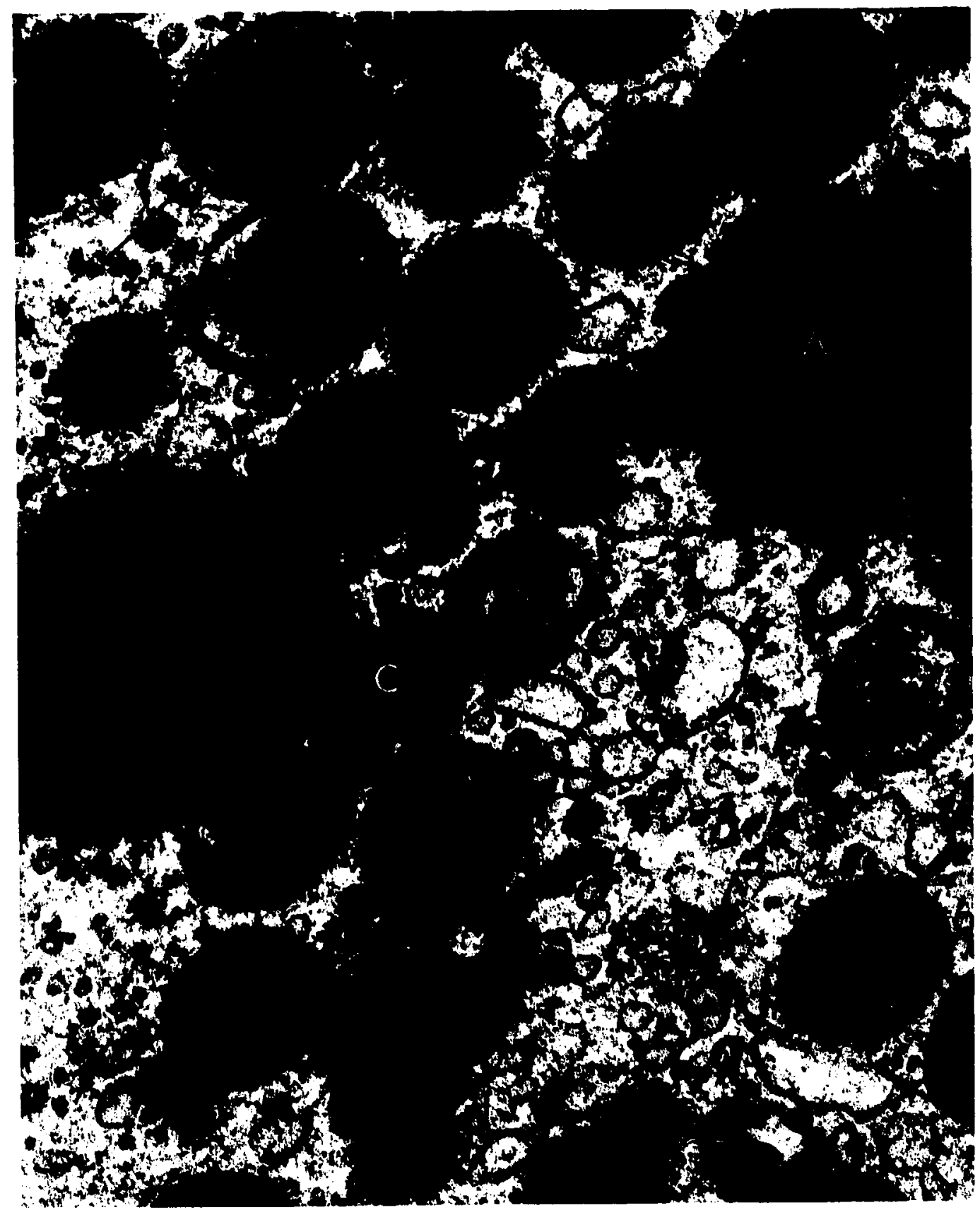

Fig.18 
61

Fig. 19. Electron micrograph of a well-demarcated inclusion body in a tumor cell. It contains various developmental stages of viral particles including mature virus (arrows). Similar inclusion bodies were demonstrated light microscopically in Figure 12. X 15,500. 


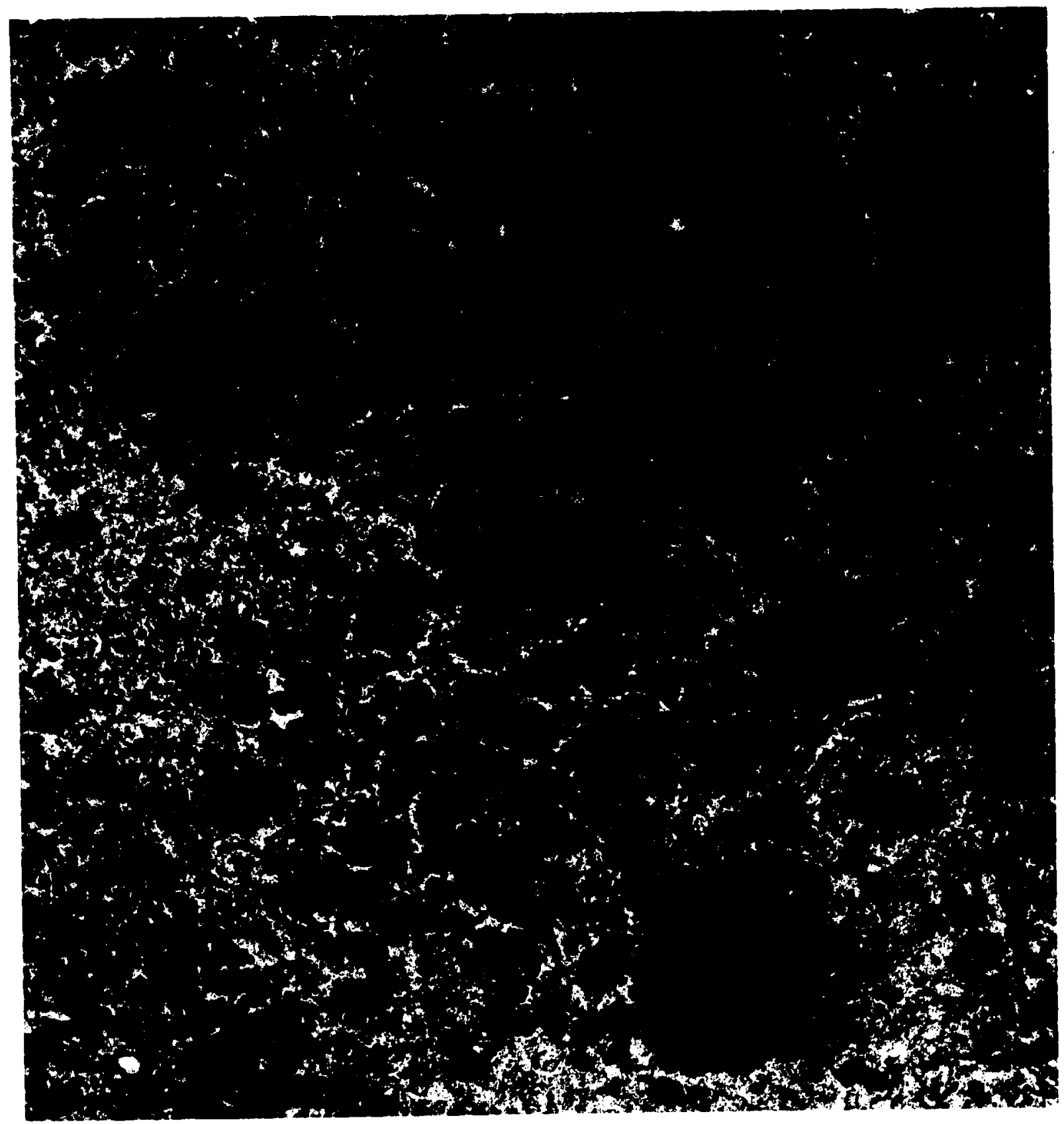

Fig.19 
to virus-producing cells. Tissue collected at the periphery of a tumor was composed of compressed alveolar septa, eosinophils, lymphocytes, and plasma cells.

In the subcutaneous tumor the cells and developmental stages of virus were similar to previous descriptions (5, 24). The cytoplasm of many cells was nearly filled with mature viral particles. Crystalline aggregates (Fig. 20) arranged in a cubic lattice were seen in the cytoplasm of 2 capillary endothelial cells within the tumor. Granular endoplasmic reticulum was prominent at the periphery of these structures. There were no virus-containing cells Immediately adjacent to this capillary.

\section{Virus isolation}

Yaba virus was isolated from lung tumor suspensions prepared from all 5 monkeys with pulmonary tumors (Table 4). Of the tumors used for virus isolation 4 of them were solid and $I$ was necrotic in the center. The largest amount of virus/gm of tissue was yielded by the latter mass which apparently was in an early stage of regression as suggested by concurrent histopathologic studies. Although a large amount of virus was isolated from macroscopically normal lung tissue-adjacent to tumors in 2 animals, virus was never isolated from lung tissue that was collected $2.0 \mathrm{~cm}$ or more from tumor nodules. Yaba virus could not be isolated from the lungs of 10 monkeys with no demonstrable 
Fig. 20. Crystalline aggregates (arrows) in the cytoplasm of 2 endothelial cells within a Yaba virusinduced subcutaneous tumor. The subunits composing these aggregates measure approximately $22 \mathrm{mu}$ in diameter. $M$ mitochondria, $\mathrm{ER}=$ endoplasmic reticulum. $\mathrm{X} 87,500$. 


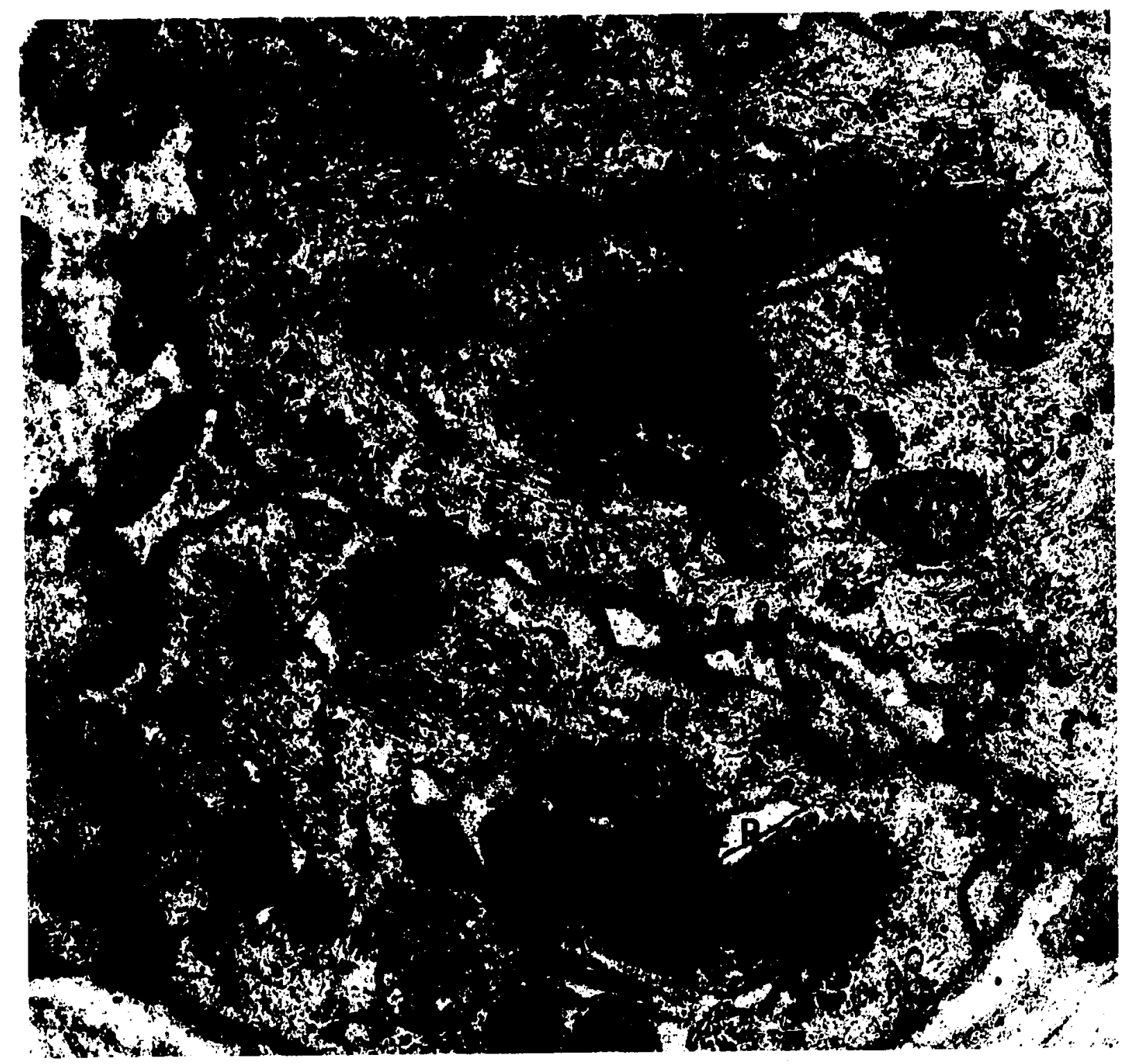

Fig. 20 
Table 4. Titer (FFU/gm) of Yaba Virus in Lung Tumors and in Iung Tissue Adjacent to the Tumors

\begin{tabular}{cccc}
\hline $\begin{array}{c}\text { Monkey } \\
\text { No. }\end{array}$ & $\begin{array}{c}\text { Weeks } \\
\mathrm{PE}\end{array}$ & $\begin{array}{c}\text { Lung } \\
\text { Tumor }\end{array}$ & $\begin{array}{c}\text { Lung Tissue } \\
\text { Adjacent } \\
\text { to the Tumors }\end{array}$ \\
\hline 14 & 4 & $2.5 \times 10^{1}$ & 0 \\
2 & 4 & $8.8 \times 10^{2}$ & 0 \\
6 & 6 & $7.5 \times 10^{1}$ & 0 \\
3 & 8 & $2.0 \times 10^{7}$ & $2.5 \times 10^{4}$ \\
7 & 12 & $4.8 \times 10^{6}$ & $3.0 \times 10^{3}$ \\
\hline & 0 & $=$ & Virus not detected.
\end{tabular}


tumors or from the spleens and tracheobronchial lymph nodes of the 14 monkeys necropsied 2-16 weeks PE.

of the weekly rectal and nasal samples collected from all the experimental animals, Yaba virus was isolated only from nasal samples collected from the monkey with the nasal tumor. The virus was isolated from the fourth week $\mathrm{PE}$ until the mass regressed. Yaba virus was never isolated from blood samples.

An adenovirus was consistently recovered in the rectal samples from 1 apparently healthy contact-exposed rhesus monkey. Yaba virus could not be isolated from the control animals.

Tumors induced by other routes of exposure

Monkeys were susceptible to Yaba virus by the subcutaneous, intravenous, intrathoracic and intrapulmonic routes. The distribution of lesions was different following each route of inoculation but the tumors were similar microscopically to previously described subcutaneous tumors $(5,9)$ regardless of the route of inoculation or the site of tumor formation. Following subcutaneous inoculation tumors were palpable at the inoculation sites in 5-10 days, maximal size was attained in 3 weeks and complete regression had occurred by 6-8 weeks post-inoculation. Multiple tumors were found in the lung, skeletal muscle (Fig. 21) and subcutaneous tissue after intravenous 
Fig. 21. Well-circumscribed solid tumors in skeletal muscle of a monkey 3 weeks after intravenous inoculation of Yaba virus. The tumors were widely disseminated but more numerous in the thigh muscles. 


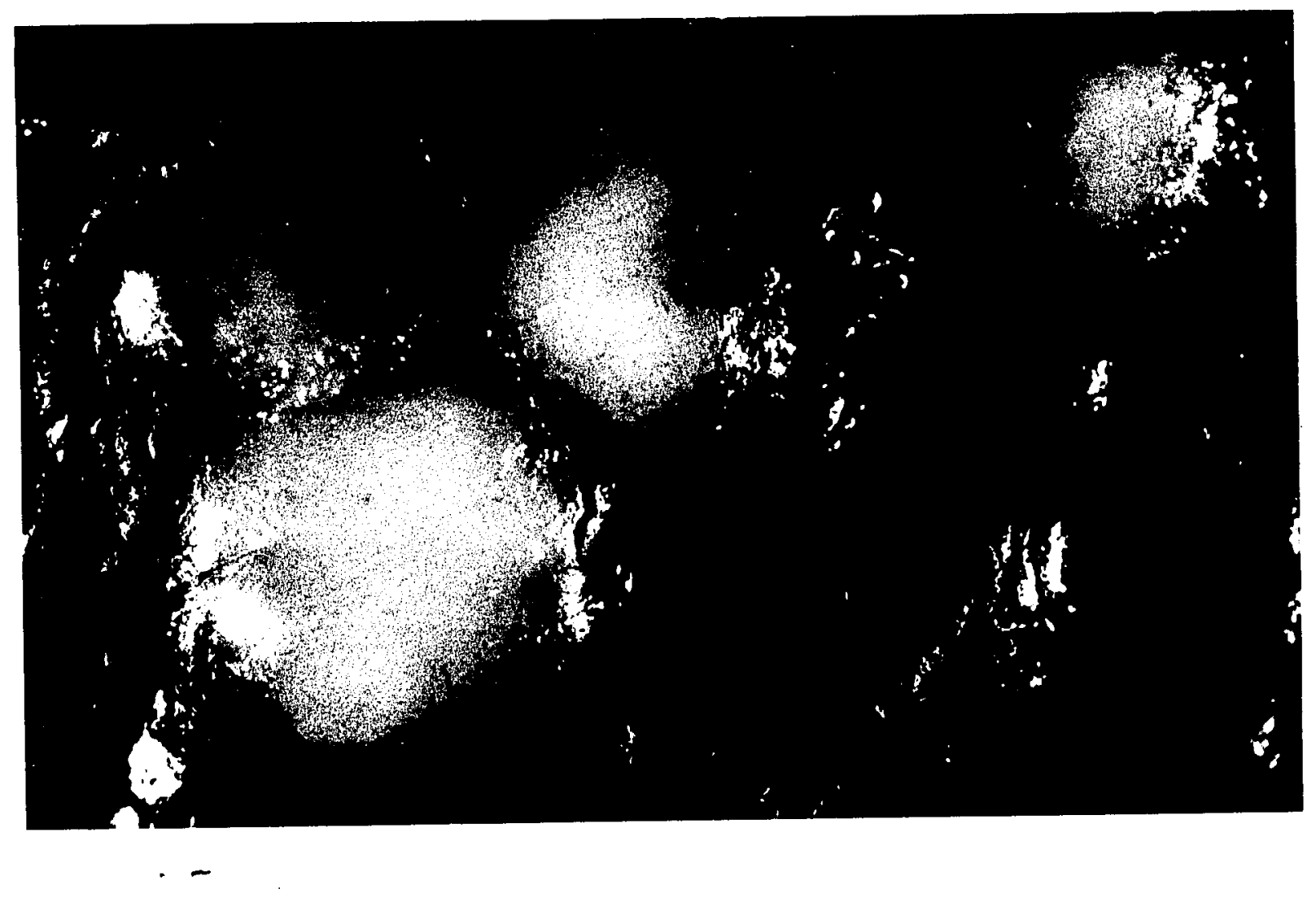

Fig. 21 
inoculation. The subcutaneous tumors were palpable 18 days post-inoculation and were widely disseminated on the arms, legs, hands, feet, face, ears, and trunk. subepicardial tumors which have been previously described following intravenous inoculation (9) were absent. After intrathoracic inoculation, subcutaneous tumors were restricted to the 2 inoculation sites on the thorax. At necropsy 3 weeks PE, well circumscribed Yaba virus-induced' histiocytomas were seeded throughout the pleural cavity (Fig. 22) and were found in the lung (primarily subpleural), diaphragm, mesentery, spleen and stomach. Following intrapulmonic inoculation, tumors were found in the right nasal cavity, skeletal muscle and subcutaneous tissue (Fig. 23). The subcutaneous tumors were palpable on the face, ears, arms, legs, hands, back, tail and perineum by the fourth week $\mathrm{PE}$ but no subcutaneous tumors were detected at the inoculation sites. The nasal tumor was observed during the fifth week PE. At necropsy 5 weeks $P E$, multiple tumors were present in skeletal muscle, but none were demonstrated in the lungs.

\section{Discussion}

The susceptibility of monkeys to dynamic Yaba virus aerosols was demonstrated by the formation of Yaba virus induced pulmonary tumors in 5 animals and a nasal tumor and secondary subcutaneous tumors in 1 animal. Rhesus and 
71

Fig. 22. Tumor nodules on the costal and diaphragmatic (D) pleurae of a monkey 3 weeks after intrathoracic inoculation of Yaba virus. Similar lesions were also present on the peritoneal surface of the diaphragm: Many subpleural lymphatics were filled with tumor cells. 


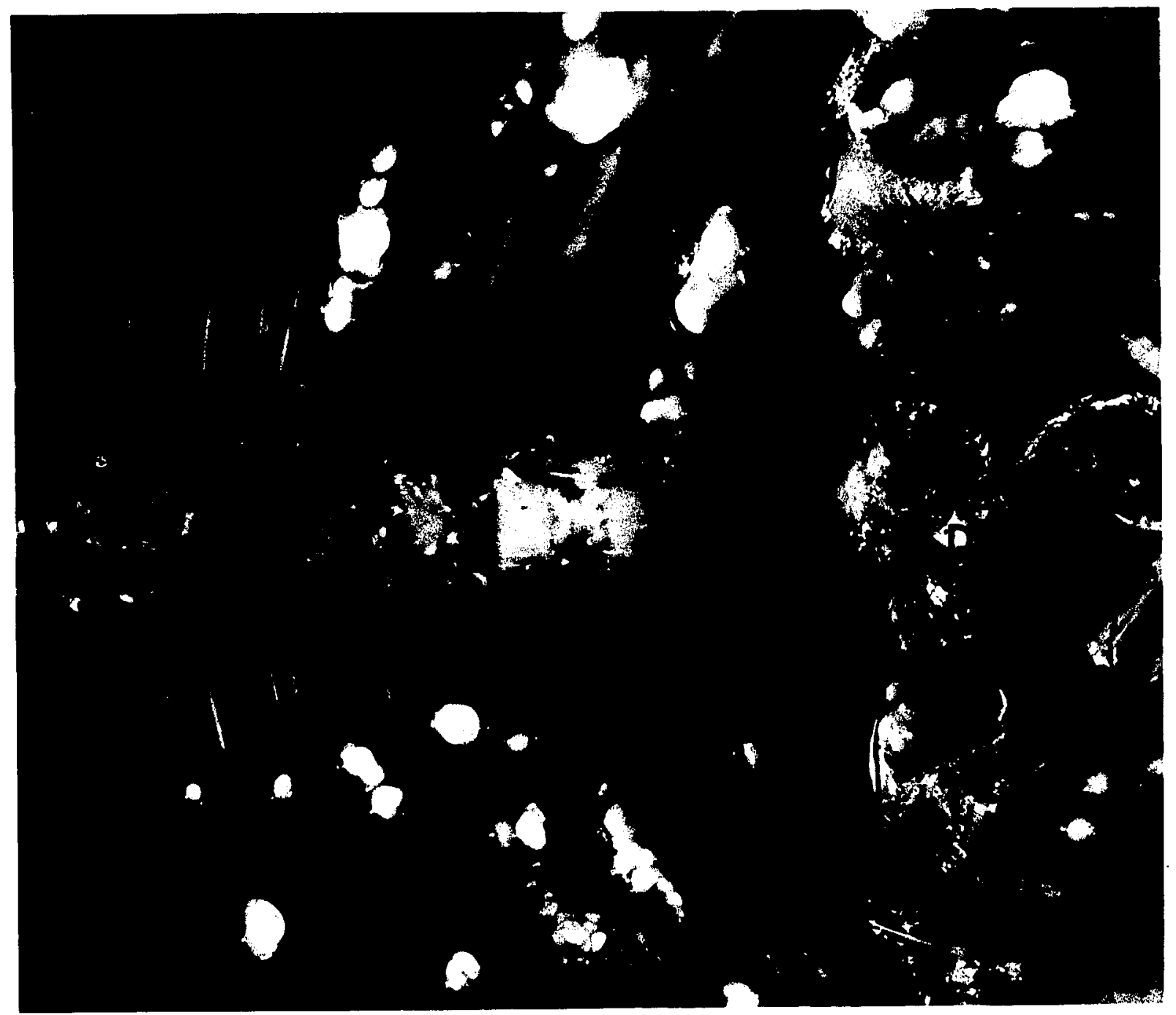

Fig. 22 
Fig. 23. Multiple subcutaneous tumors on the thighs and perineum of a monkey 5 weeks after intrapulmonic inoculation of Yaba virus, demonstrating the most severely affected sites on the body. The largest tumor (arrow) is located between the ischial pads. 


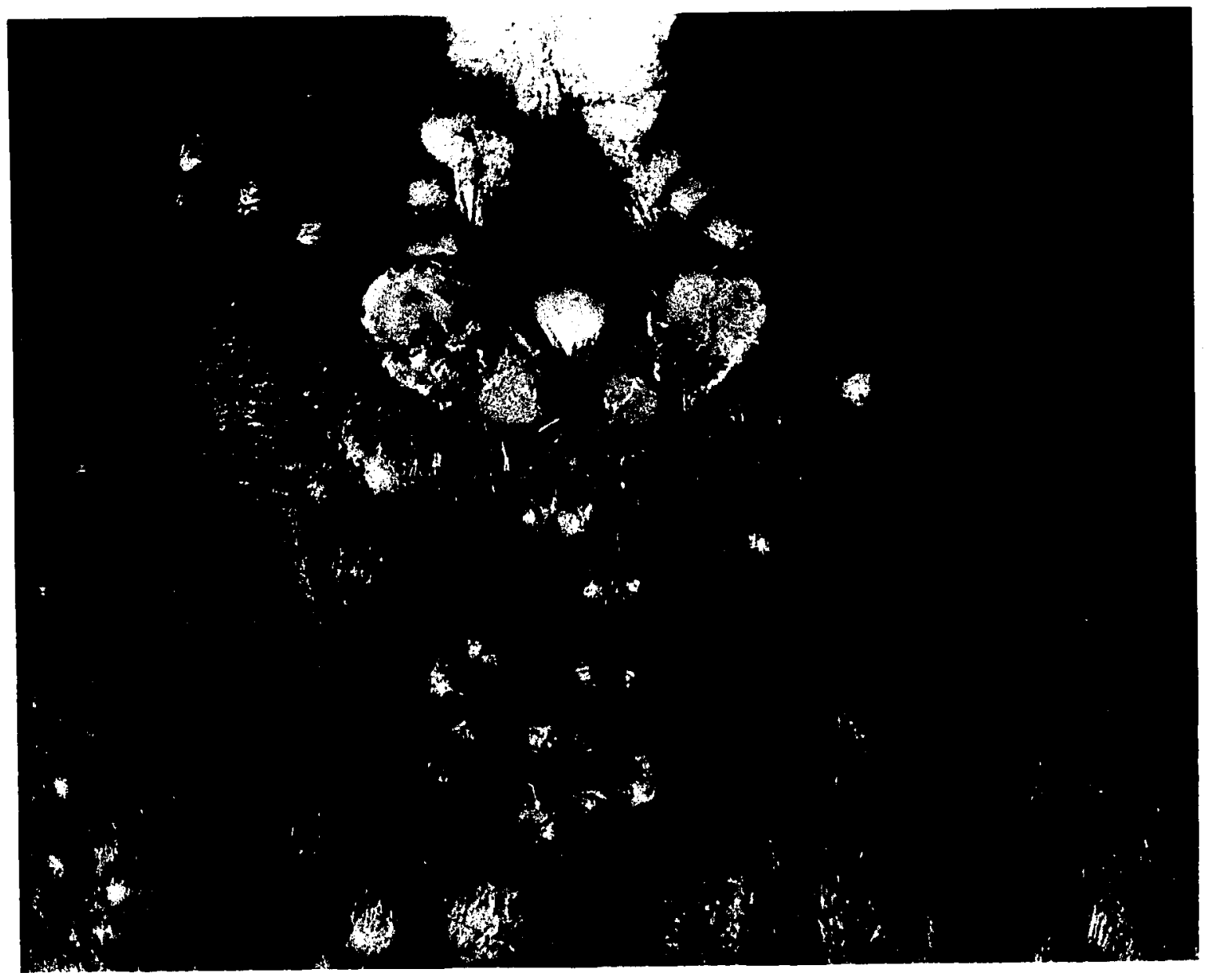

Fig. 23 
cynomolgus monkeys were equally susceptible, fust as they are following subcutaneous inoculation (5). Since monkeys and man are susceptible to comparable subcutaneous doses of Yaba virus (10), the susceptibility of monkeys via aerosol exposure strongly suggests a potential risk to man by the same route. Laboratory personnel who work with highly concentrated preparations of the virus should be particularly aware of the potential danger of this agent.

After the susceptibility of monkeys to aerosoljzed Yaba virus was confirmed, it was assumed that all monkeys exposed to similar virus doses would develop pulmonary tumors, based on our subcutaneous exposure studies. A simple dose dependent-time relationship was supported by the observation that the greatest number and largest pulmonary tumors were present in the animal with the largest dose of virus retained in the lungs. This assumption was contradicted, however, by finding that pulmonary tumors were present at 4 and 8 weeks PE in 2 monkeys with the smallest doses retained in the lung $\left(5.4\right.$ and $6.0 \times 10^{2}$ FFU/gm of lung tissue) and were absent in 6 monkeys with larger retalned doses necropsied 10-16 weeks PE. Four monkeys from this latter group were periodically radiographed during the $P E$ period and the thoracic radiographs were al]. . normal. Factors which could have affected the morbidity rate include patterns of viral deposition and retention, mechanisms of viral clearance from the respiratory system 
and the presence or absence of an anti-viral inhibitory substance (interferon-like) in the lung. Interferon production has been demonstrated in alveolar macrophages (37) and in lung extracts (38).

A pathogenicity study of the Yaba virus-induced pulmonary lesions was restricted by the low morbidity rate. Although the initial proliferative response occurred in the alveolar septa, the origin of the proliferating cells was not unequivocally elucidated by this study. Ultrastructurally, however, the findings suggested that Yaba virus was capable of eliciting similar histopathologic manifestations in 2 or more different cell types. Virus replication was observed in cells closely resembling those described in Yaba virus-induced subcutaneous histiocytomas $(5,9,24)$ as well as in cells compatible with the granular pneumonocyte (type II cells) of the alveolar epithelial lining (29-33). Virus replication was not seen In alveolar macrophages. There was no apparent predilection for tumors to originate in or near pre-existing lesions of pulmonary acariasis.

In comparison to the subcutaneous tumors, more Invasiveness was demonstrated in the lung tumors as manifested by infiltration of bronchioles, lymphatics and blood vessels. Absence of regression in 2 large tumors at 12 weeks $P E$ was indicative of a prolonged course since subcutaneous tumors induced by comparable virus doses 
completely regressed within 6 weeks following inoculation. There was evidence, however, that the pulmonary lesions would have spontaneously regressed just like Yaba virusinduced subcutaneous tumors. In a few lesions 8 and 12 weeks $\mathrm{PE}$, central areas of necrosis were prominent and were identical microscopically to regressing subcutaneous tumors. The highest virus concentration was present in a lesion that was characterized by central necrosis. The pathogenetic mechanisms which could have been responsible for development of the nasal tumor include direct impingement of virus on the nasal mucosa with subsequent penetration into the submucosa, secondary localization of virus via blood or lymph from a primary site of infection, and massive clearance of virus from the lower respiratory tract via the ciliary escalator. Since 10\% of the infectivity in the aerosol was associated with large particles (over $8 \mathrm{u}$ ), the nasal mucosa was subject to direct impingement. The other 2 possibilities must be given equal consideration, however, since the monkey which was Inoculated intrapulmonically as a positive control also developed a tumor in the right nasal cavity. Visceral involvement in the aerosol-exposed monkey was not confirmed although splenomegaly and increased densities in the right lung appeared and disappeared radiographically between 12 and 20 weeks $\mathrm{PE}$. 
The subcutaneous tumors which appeared during proliferation, reactivation, and regression phases of the nasal tumor were confined to the hands, feet, perineum and tail. Vascular dissemination, direct implantation of virus from the nasal tumor, and fecal excretion with secondary infection were considered as possible routes of transmission to the subcutaneous sites. Since no epidermal defects were detected at the tumor sites and virus was never isolated from weekly rectal specimens, vascular dissemination was considered as the probable route of transmission. An explanation for the distribution of the subcutaneous lesions cannot be given. Tumor formation as a reflection of the vascularization pattern was discarded since vascularization of the skin is uniformly scant except for the richly vascularized skin of the forehead, scalp, and sex-skin (39).

All of the sequential phases of intracytoplasmic viral maturation as previously described in Yaba virusInduced subcutaneous tumors (9) were recognized ultrastructurally in the pulmonary tumors. Although granular endoplasmic reticulum and Golgi complexes were regularly detected adjacent to the areas of viral synthesis, a direct connection was not seen between these organelles and the unit-membranes surrounding immature viral particles. Cylinarical structures, however, were frequently seen emanating from the aggregates of smooth membranes in the cytoplasm, and subsequently extending into the sites of 
viral synthesis. Many of these cylinders were covered with subunits very similar to those surrounding immature viral particles. It was tempting to speculate that one form of early viral membranogenesis was represented by the peripherally produced cylinders acquiring subunits within the area of synthesis, breaking up into small segments, and subsequently sequestering viroplasm to form type 1 particles. On the other hand, the aggregates of smooth membranes could represent only a surplus of cellular membranes produced by the proliferating cells and, therefore, the membranes and cylinders may be nonspecific products of the infected cells. De Harven and Yohn (24) suggested that the cylinders may also represent aberrant forms of virus.

Crystalline aggregates similar to those seen in two capillary endothelial cells within a secondary subcutaneous tumor have been previously reported in Yaba virus-induced subcutaneous tumors (24), in Rous sarcoma-induced tumors in monkeys (40, 41), dogs (42) and hamsters (43), in cells infected with non-oncogenic viruses (44-46), and in normal monkey parathyroid glands (47). These aggregates apparently represent either a latent virus infection or a nonspecific response of the cell which can be triggered $\checkmark$ by viral infections and perhaps by other stimuli as well. Although the crystalline aggregates in the endothelial cells are apparently nonspecific, their presence in cells which were not immediately surrounded by tumor cells may support 
the concept that vascular dissemination was responsible for the secondary subcutaneous tumors. The honeycombed membranous structures were morphologically distinct from the crystalline aggregates. Their significance was not determined.

\section{Summary}

Aerosol transmission of Yaba virus was demonstrated by tumor formation in 5 of 12 rhesus and 1 of 3 cynomolgus monkeys. Solltary or multiple pulmonary tumors were found in 5 of 14 monkeys necropsied between 2 and 16 weeks post exposure. In a sixth animal a large deforming nasal tumor and multiple subcutaneous tumors occurred. Compared to Yaba virus-induced subcutaneous tumors, the onset of tumor formation was delayed and the course was prolonged in aerosol-exposed monkeys. The susceptibility of individual monkeys to aerosol transmission could not be correlated with the dose of virus retained in the lung or with the interval between exposure and euthanasia. Horizontal transmission to cagemates was not observed.

The pulmonary and nasal tumors were similar morphologically to Yaba virus-induced subcutaneous tumors. The sites of the initial proliferative response were demonstrated in the alveolar septa. Compression of bronchl and bronchioles and invasion of bronchioles, lymphatics and blood vessels were occasionally observed. Ultrastructurally, 
81

sites of viral replication were seen in granular pneumonocytes and in cells similar to those composing Yaba virus-induced subcutaneous histiocytomas.

It was concluded that man could conceivably be susceptible to aerosolized Yaba virus. 


\section{CHAPTER II}

\section{IMMUNOLOGIC RESPONSE OF MONKEYS TO AEROSOLS OF YABA VIRUS}

\section{Introduction}

Yaba poxvirus was originally isolated from tumor material collected during an outbreak of naturally occurring subcutaneous histiocytomas in a colony of rhesus monkeys (Macaca mulatta) at Yaba, Nigeria (1). Subcutaneous inoculation of the virus into man (2), Asiatic monkeys (3-6), and African monkeys born and reared in the United States induced subcutaneous tumors that were indistinguishable microscopically from the spontaneous tumors in monkeys. Based on the apparent resistance displayed by imported African monkeys, Ambrus and Strandström (3) proposed that the virus was endemic in certain areas of Africa and that the monkeys consequently acquired immunity to the virus in their natural habitat.

In Immunologic studies of animals with Yaba virusinduced subcutaneous tumors, Metzgar et al. (7) found that persistent growth of established tumors was unimpaired by high levels of circulating antibody but that humoral antibody was effective in preventing secondary tumor formation. Complement-fixing (CF) antibody and palpable tumors were 
usually both detected by the tenth day post exposure (PE) and maximum antibody titers which were reached in 14-21 days $\mathrm{PE}$ were maintained until the tumors regressed or were surgically excised. After the tumors disappeared, immunity was usually of short duration. They demonstrated a direct correlation between $\mathrm{CF}$ titers and in vivo neutralization titers.

As previously described (8), pulmonary and nasal tumors were experimentally induced in monkeys by aerosol transmission of Yaba virus. The objectives of this study were: (a) to define the humoral response in monkeys exposed to an aerosol of Yaba virus utilizing complement-fixation and neutralization tests, (b) to compare the humoral response in the aerosol-exposed monkeys to the response in monkeys with Yaba virus-induced subcutaneous tumors, (c) to compare CF antibody titers using 3 different sources of antigen and (d) to demonstrate and localize viral antigen in the pulmonary tumor cells by immunofluorescence.

\section{Materials and Methods}

Cell culture.--A Cercopithecus aethiops monkey kidney cell line (CV-I) was used for preparing inocula, for titrating the $\mathrm{CF}$ antigens and for performing the in vitro neutralization tests. The cell line was maintained and the assay procedure was performed as described previously (8). Viral titers were expressed as the number of focus forming units (FFU)/mI. 
Animals.--Immunologic studies were performed on 16 aerosol-exposed rhesus (Macaca mulatta) and cynomolgus (Macaca fascicularis) monkeys and on 4 subcutaneouslyInoculated rhesus monkeys. Exposure, clinical, pathologic and virological data on the aerosol-exposed monkeys have been previously described ( 8 ). They retained $8.6 \times 10^{3}$ to $1 \times 10^{5} \mathrm{FFU}$ of Yaba virus in the lungs. The 4 rhesus monkeys were inoculated in multiple subcutaneous sites with approximately $2 \times 10^{5} \mathrm{FFU}$ of virus, using tumor homogenate or Yaba virus-infected $\mathrm{CV}-1$ cell culture suspensions as inocula. The subcutaneous tumors were all palpable by 10 days $\mathrm{PE}$ and the animals were subsequently necropsied 3-14 weeks PE. In 2 monkeys (No. 17 and 18) subcutaneous tumors were blopsied at 4 weeks PE and the necropsies performed 4 weeks later. In 1 monkey (No. 19) subcutareous tumors were palpable in 5 days, maximal size was attained in 3 weeks and complete regression was recorded at 5 weeks $\mathrm{PE}$. This monkey was challenged subcutaneously 7 weeks PE with $1.5 \times 10^{6} \mathrm{FFU}$ and intravenously 11 weeks PE with $4 \times 10^{5} \mathrm{FFU}$ but the animal was resistant to challenge by both routes of exposure. One monkey (No. 20) was not biopsied prior to necropsy at 3 weeks $P E$.

Serum.-Pre-inoculation and weekly post-inoculation blood samples were collected from the femoral vein for serologic studies. The serum was stored at $-30^{\circ} \mathrm{C}$ until tested. 
Immunofluorescence.--Representative sections of lung tumors, lung from each aerosol-exposed monkey, and a subcutaneous tumor were frozen in liquid nitrogen and stored at $-70^{\circ} \mathrm{C}$. Frozen sections were cut $5 \mathrm{u}$ thick in a cryostat, fixed in cold acetone for 10 minutes, and washed 3 times with phosphate-buffered saline at $\mathrm{pH}$ 7.2. The tissue sections were layered with a Yaba virus-specific, fluorescein-conjugated gamna globulin preparation ${ }^{l}$ after rhodamine-labeled bovine albumin had been added to the conjugate at a concentration of $1: 6$. The preparations were incubated. at $37^{\circ} \mathrm{C}$ for 60 minutes, rinsed 3 times with phosphate-buffered saline and mounted in glycerol. The specificity of the reaction was determined by the staining of Yaba virus-infected cells in vivo and in vitro, by the fallure to stain normal lung tissue, and by successful blocking of fluorescence with unconjugated anti-Yaba virus antiserum.

Complement-fixation test. - Three antigen preparations were used for evaluating the CF antibody response of each monkey. A subcutaneous tumor extract (STE) was prepared from multiple subcutaneous tumors surgically excised from an animal 25 days following subcutaneous inoculation. The tumors were finely minced and were homogenized in a Ten

$1_{\text {The fluorescein-conjugated gamma globulin prepar- }}$ ation was obtained from Dr. D. Yohn, Roswell Park Memorial Institute, Buffalo, New York. 
Broeck grinder as a $10 \% \mathrm{w} / \mathrm{v}$ suspension in equal volumes of fluorocarbon and phosphate-buffered saline. The homogenate was sonicated for 5 minutes and 2 fluorocarbon extractions were performed. The pooled extractions were used as the complement-fixing antigen. A second antigen (ITH) was prepared as a $10 \% \mathrm{w} / \mathrm{v}$ suspension of lung tumor collected from an animal necropsied 12 weeks after aerosol exposure to Yaba virus. Minced tumor tissue was suspended in medium 199 diluted 1:I with bovine amniotic fluid and was homogenized in a Ten Broeck grinder. The homogenate was frozen and thawed 4 times, centrifuged lightly, and the supernatant used as the antigen. Maintenance medium (MM) which was decanted from Yaba virus-infected CV-I celI cultures was utilized as the third antigen. Since this medium consisting of medium 199 supplemented with $2 \%$ agamma calf serum was collected 24 days after inoculation, numerous secondary foci had already formed on the cell sheet. Virus titrations of STE, LTH, and MM revealed $6.5 \times 10^{6}, 6.75 \times$ $10^{6}$, and $2.5 \times 10^{3} \mathrm{FFU} / \mathrm{ml}$ respectively. Block-titrations were performed in which serial dilutions of each antigen were reacted simultaneously with serial dilutions of hyperimmune anti-Yaba virus antisera. Based on the results from these titrations, dilutions of $1: 8,1: 8$ and 1:4 were used for STE, ITH and MM respectively in all the complement-fixation tests. 
The microtiter method adapted for complementfixation (9) was employed and $0.025 \mathrm{ml}$ of each reagent was used. Two units of guinea pig complement, $2 \%$ sheep erythrocyte suspensions and 2 units of hemolysin were consistently used in the tests. Sera and antigens were heated at $56^{\circ} \mathrm{C}$ for 30 minutes and the sera were diluted in 2-fold steps. Veronal buffer was used in making the dilutions for each reagent. Complement was fixed at $4^{\circ} \mathrm{C}$ for 18 hours after which the sensitized erythrocyte suspension was added. The plates were then incubated for 30 to 45 minutes at $37^{\circ} \mathrm{C}$ and in some experiments for an additional 60 minutes at $4^{\circ} \mathrm{C}$. The titer of the antisera was expressed as the reciprocal of the highest dilution capable of fixing $50 \%$ of the complement.

Virus neutralization test.--Undiluted and 10-fold dilutions of sera were tested for neutralizing antibody. Serum dilutions were made in medium 199 diluted $1: 1$ with bovine anmiotic fluid. Equal quantities of sera and of a $10-3$ or $10-^{4}$ dilution of stock virus containing $1.25 \times 10^{6}$ $\mathrm{FFU} / \mathrm{ml}$ were mixed and incubated at $25^{\circ} \mathrm{C}$ for 60 minutes. The virus-serum mixture was inoculated onto confluent $\mathrm{CV}-1$ coverslip cultures in Leighton tubes and the neutralizing antibody level determined microscopically by the focireducing capacity of the virus-serum mixture. 
Results

Serologic tests.--Complement-fixing antibodies were demonstrated in sera from 3 of the 4 subcutaneousiyinoculated monkeys and from 5 of the 6 aerosol-exposed monkeys that developed tumors after exposure to Yaba virus (Table 5). In the aerosol-exposed monkeys CF antibody was first detected at 3 weeks $P E$ in 3 monkeys and at 4 and 6 weeks $P E$ respectively in the other 2 animals. The peak antibody levels could be determined only in the monkey (No. 12) with the nasal tumor (Fig. 24) since the monkeys with Yaba virus-induced pulmonary tumors were euthanatized prior to developing a peak antibody response. In the latter animals the highest antibody levels were recorded on the day of euthanasia. The pattern of antibody response was similar with all 3 antigens but the titers were lower when the MM antigen was used (Table 6). The levels of CF antibody could not be correlated with the virus concentration in the tumors. Complement-fixing antibody was not detected in those monkeys in which tumors were not demonstrated nor in 1 aerosol-exposed monkey with a small lung tumor at 4 weeks $\mathrm{PE}$.

In the monkeys inoculated subcutaneously CF antibody was already present on the seventh day $P E$ which corresponded roughly to the onset of the tumors. The maximum titers were 2048 in each monkey but the duration of the response was not determined since the monkeys were euthanatized 
Table 5. Complement-Fixing Antibody Titers in 5 Aerosol-Exposed and 3 SubcutaneouslyInoculated Monkeys with Yaba Virus-Induced Tumors (STE Antigen)

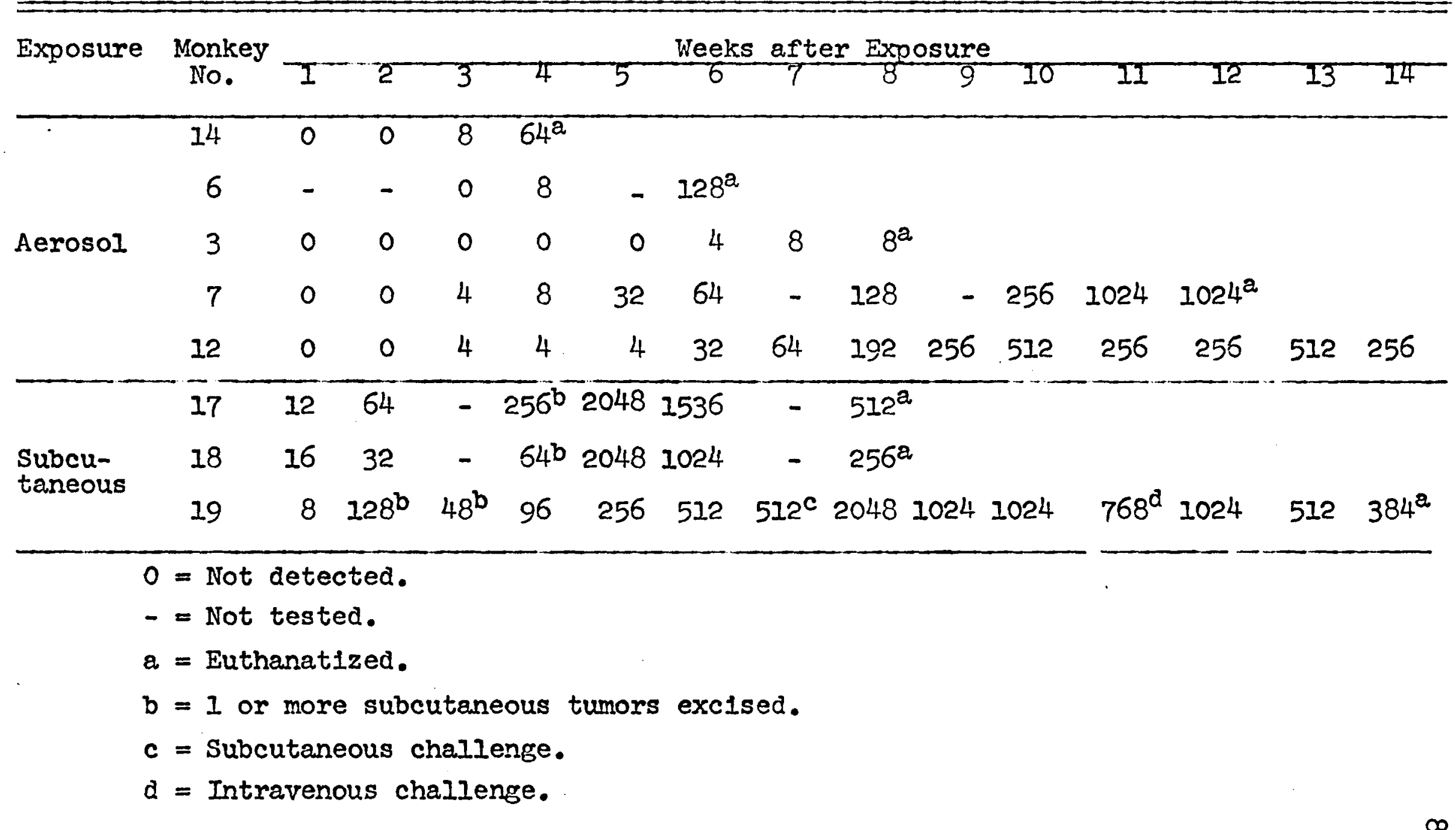


Fig. 24. Complement-fixing antibody levels in an aerosol-exposed monkey that developed nasal and subcutaneous tumors at various intervals after exposure. The STE preparation was used as the antigen. The nasal and subcutaneous tumors were completely regressed by 20 and 22 weeks after exposure respectively. 
91

$O=$ CLINICAL DETECTION OF NASAL TUMOR

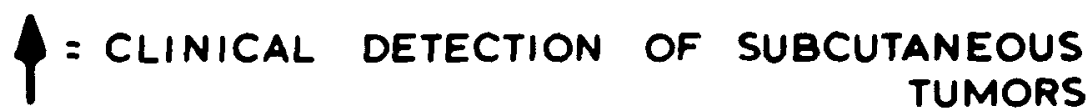

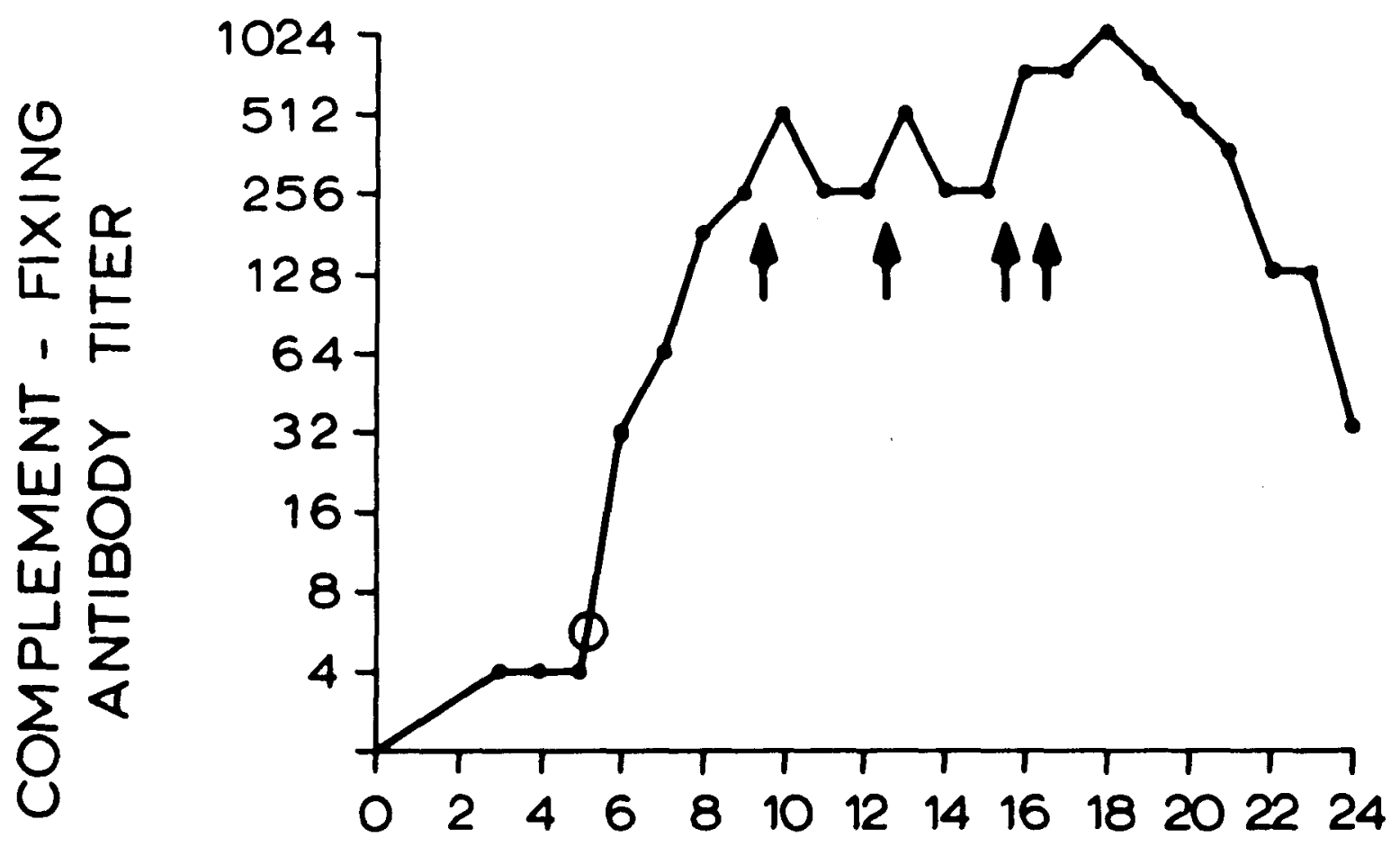

FIG.24: WEEKS POST EXPOSURE 
Table 6. Comparison of the CF Antibody Titers Detected by 3 Different Antigen Preparations in 4 Monkeys with Yaba Virus-Induced Pulmonary Tumors

\begin{tabular}{|c|c|c|c|c|c|}
\hline $\begin{array}{l}\text { Monkey } \\
\text { No. }\end{array}$ & $\begin{array}{l}\text { Euthanasia } \\
\text { (Weeks PE) }\end{array}$ & \multicolumn{3}{|c|}{$\begin{array}{l}\text { Highest } \\
\text { CF titersa }\end{array}$} & $\begin{array}{l}\text { Virus Conc } \\
\text { in Tumors } \\
\text { (FFU/gm) }\end{array}$ \\
\hline 24 & 4 & 64 & - & 4 & $2.5 \times 10^{1}$ \\
\hline 6 & 6 & 128 & 64 & 2 & $7.5 \times 10^{1}$ \\
\hline 3 & 8 & 8 & 8 & 4 & $2.0 \times 10^{7}$ \\
\hline 7 & 12 & 1024 & 1024 & 512 & $4.8 \times 10^{6}$ \\
\hline
\end{tabular}

- = Not tested.

$a_{\text {Highest }} \mathrm{CF}$ titers were detected in samples collected just prior to euthanasia. 
before the antibodies disappeared. The effect of subcutaneous and intravenous challenges on the pattern of antibody response in 1 animal is shown in Table 5. The antibody response was greater following subcutaneous challenge than after intravenous challenge. In 1 monkey (No. 20) CF antibody was still undetectable 21 days $\mathrm{PE}$ although subcutaneous turnors were palpable on the tenth day $\mathrm{PE}$.

Serum-neutralizing antibodies were demonstrated in the same monkeys in which $\mathrm{CF}$ antibodies were detected. The pattern of the neutralizing antibody response in aerosolexposed and subcutaneously-inoculated monkeys paralleled the pattern of the $\mathrm{CF}$ antibody response except that neutralizing antibody was detected 2 weeks earlier in 1 aerosol-exposed monkey (No. 3) and the maximal titer persisted longer in the monkey with the nasal tumor (No. 12). The titer of neutralizing antibody in the latter animal was virtually unchanged from the ninth to the twenty-second week $P E$, neutralizing approximately $100 \mathrm{FFU} / \mathrm{ml}$ at a dilution of 1:100. Similar maximal titers were also demonstrated in an aerosol-exposed monkey with multiple pulmonary tumors (No. 7) and in the subcutaneously-inoculated monkeys. Complement-fixing and neutralizing Yaba virusantibodies were not detected in pre-inoculation serum samples. They were also undetectable in 14 weekly serum samples from the contact-exposed cagemate of the monkey with the nasal tumor. 


\section{Immunofluorescence.--Virus antigen was readily}

demonstrated in the cytoplasm of tumor cells by the direct fluorescent antibody method. In early lung lesions, small single or multiple areas of bright fluorescence appeared in widely scattered proliferating alveolar septal cells. A majority of the tumor cells in animals with longer $\mathrm{PE}$ intervals were characterized by bright fluorescent foci randomly distributed in a diffusely fluorescing cytoplasmic matrix (Fig. 25). This pattern of distribution was identical to that demonstrated in Yaba virus-induced subcutaneous tumors. The number of nonfluorescing cells admixed among the fluorescing cells lessened as the PE interval increased. Specific nuclear fluorescence was not observed in the tumor cells. Fluorescence was absent in histologically normal lung tissue from each monkey, including the animals with tumors.

\section{Discussion}

The humoral response to Yaba virus was essentially the same in aerosol-exposed and subcutaneously-inoculated monkeys but there were variations in the response as a reflection of the differences in the course of tumor development following these routes of exposure. The delayed onset of the humoral response in aerosol-exposed monkeys was apparently associated with the delayed onset of tumor formation in these animals. After initial detection, the 
Fig. 25. Immunofluorescence. Tumor cells from the lung of an animal 12 weeks after aerosol-exposure to Yaba virus illustrating bright fluorescent foci of viral antigen (arrows) distributed in a diffusely fluorescing cytoplasmic matrix. $N=$ nucleus. 
96

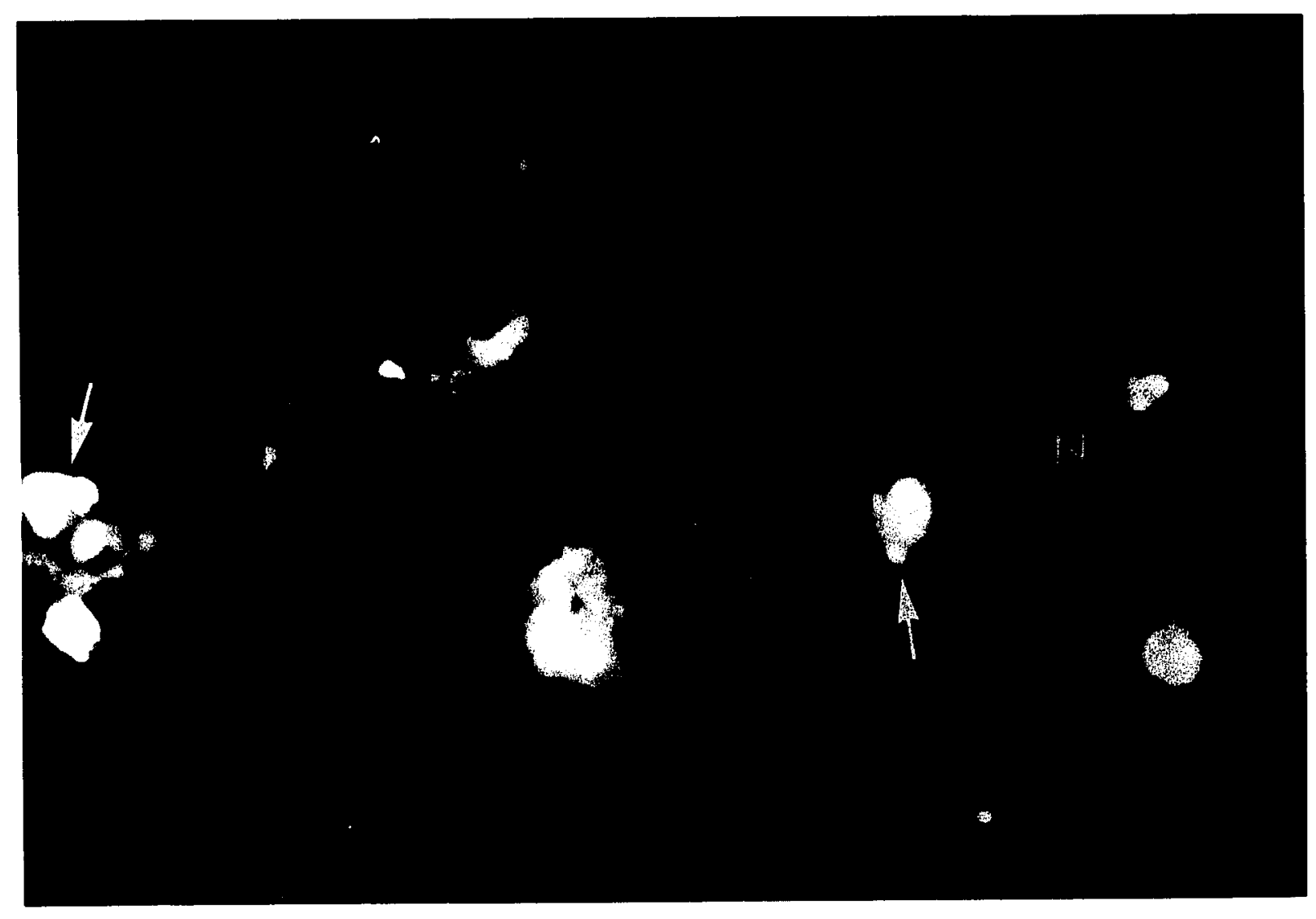

Fig. 25 
rise in the antibody level was consistently sharper in animals inoculated subcutaneously and was correlated with the rapid proliferation and relatively early attainment of maximal growth in subcutaneous tumors compared to the. more prolonged course and gradual rise in antibody titers in aerosol-exposed monkeys. The peak complement-fixing and neutralizing antibody levels were apparently comparable fol.Jowing both routes of exposure although the animals with Yaba virus-induced pulmonary tumors were necropsled before their maximal titers were reached. Following both routes of exposure, tumors were occasionally demonstrated before serum antibody was detected.

The $\mathrm{CF}$ antigens prepared from subcutaneous tumors (STE) and lung tumors (ITH) were equally sensitive in measuring the $\mathrm{CF}$ antibody response both in aerosol-exposed and subcutaneously-inoculated animals. The antigenic components may have been similar or identical in these preparations. Although titers were consistently lower when measured with the $\mathbb{M}$ antigen preparation, the pattern of antibody response was similar to that recorded with the tumor extracts. Such uniformity was not characteristic of all antigens prepared from infected cell cultures, however, and the MM preparation used in this study was selected for testing purposes only after the uniformity and reproducibility of lts results were demonstrated during preliminary studies. During the screening of other infected cell 
culture maintenance media and infected CV-I cell suspensions for their complement-fixing properties, we found that identical sera reacted very differently and unpredictably with the various antigen preparations. Antibody levels were undetectable with some preparations while others detected titers only slightly lower than the levels demonstrated by tumor extracts. This variation in sensitivity could not be consistently correlated either with the infectivity titers or with the post-inoculation collection or harvesting intervals. Yohn and his colleagues (10) have recently demonstrated several antigenically distinct $\mathrm{CF}$ Yaba virus antigens both in subcutaneous tumor extracts and in infected $\mathrm{CV}-1$ cell cultures. They found that cell cultures regularly contained fewer antigens than the turnor extracts, the principal difference being fewer soluble antigens. The differences demonstrated among the various antigen preparations in the study reported here were undoubtedly a reflection of the number and quantity of different antigens present in these various preparations. Heating at $56^{\circ} \mathrm{C}$ for 30 minutes did not noticeably decrease the antigenicity of the preparations used in this study but decreased antigenicity was observed following the heating of several other preparations during the screening tests, indicating the heat lability of 1 or more $C F$ antigens.

In the animals inoculated subcutaneously, CF titers detected by the tumor extracts were higher than those 
previously reported $(6,7)$, reaching 2048 in 3 of 4

animals. Since there are different Yaba CF antigens, the higher titers could reflect the quality of the antigen preparation rather than a difference in the antibody response. Following both routes of exposure there was a suggestion that different antigens were responsible for the humoral response at different stages of the disease since the results using the same antigen preparation were often inconsistent among weekly serurn samples from the same animal. Cellular release of different developmental stages of the virus could be a factor in altering the antigenic stimulus and subsequent in vivo antibody response. Some CF antigens are undoubtedly localized in the viral protein coats as exemplified by gradual depletion of CF antigen following repeated fluorocarbon extractions and different antigens could be preferentially localized in each protein coat.

In the animal challenged intravenously, a neutral-. Izing effect of humoral antibody on circulating virus was suggested by the poor antibody response (Table 5) and by the absence of tumors 3 weeks $\operatorname{PE}(6,8)$. In contrast the aerosol-exposed monkey which developed a nasal turnor at approximately 4 weeks $P E$ developed multiple subcutaneous tumors 9-17 weeks $P E$ in spite of high levels of neutralizing antibody. The virus could have been disseminated to these sites early in the $\mathrm{PE}$ period before neutralizing antibody was formed but a 4 month latent period is unlikely. 
Ambrus et al. (4) reported a latent period of 70 days following subcutaneous inoculation of monkeys with $10^{-6}$ dilutions of a virus suspension. In our experience subcutaneous tumors regularly appear in 10 days following subcutaneous inoculation of $20 \mathrm{FFU}$. Rather than a long latent period, infective circulating virus was probably either intracellular or resistant to the neutralizing antibody.

In the immunofluorescent study small areas of intracytoplasmic fluorescence observed in scattered alveolar septal cells in the early lesions were compatible with the fluorescent pattern described in cultured cells 48 to 72 hrs post-inoculation (11, 12, 13) The small areas of fluorescence enlarged to form large bright fluorescent foci and in more advanced lesions ( 12 weeks $P E$ ) these foci were distributed in a diffusely fluorescing cytoplasmic matrix. The bright fluorescent foci corresponded to the inclusion bodies described histopathologlcally and ultrastructurally (8). The diffuse pattern of cytoplasmic fluorescence was similar to the pattern in microtumors in infected $\mathrm{CV}-1$ cells 18 to 21 days post-inoculation.

The mechanism of tumor regression was not elucidated by this study. Niven et al. (5) considered the mononuclear host response surrounding the tumors as a contributing factor to tumor regression but Sproul et al. (6) proposed that regression was probably solely the result of viral 
cytopathogenicity in individual tumor cells. If the latter theory were true, the in vivo and in vitro virus-host interaction must be different because virus-infected cells In vitro can be maintained over 60 days without cell lysis, a period within which most tumors have completely regressed. Metzgar et al. (7) failed to localize intracellular antibody in tumor cells by immunofluorescence.

\section{Summary}

Complement-fixing and neutralizing antibody responses to Yaba virus were determined in 16 aerosol-exposed and 4 subcutaneously -inoculated monkeys. The humoral response was similar following both routes of exposure when correlated with the course of tumor development. Comparable complementfixing antibody titers were detected using subcutaneous tumor and lung tumor extracts as complement-fixing antigens In contrast to the consistently lower titers obtained using infected cell culture preparations. The appearance and peak levels of complement-fixing and neutralizing antibody titers occurred simultaneously. In spite of high neutralizing antibody serum titers, $I$ aerosol-exposed monkey developed multiple subcutaneous tumors at various intervals post exposure.

Virus antigen was demonstrated in the cytoplasm of lung tumor cells by immunofluorescence. The fluorescent foci corresponded to the inclusion bodies observed light microscopically and ultrastructurally. 


\section{Introduction}

This study was designed to develop techniques in raising germfree monkeys and was stimulated by the need for experimental monkeys free of spontaneous diseases and free of naturally acquired immunity to human viral hepatitis. Spontaneous diseases such as bacillary dysentery, pneumonia, and parasitic infestations commonly preclude successful completion and accurate interpretation of experimental studies in monkeys. Moreover, the potential transmission of Herpes simiae B infection and tuberculosis to laboratory personnel is also a major concern. The use of germfree monkeys will eliminate the spontaneous disease problems and prevent previous exposure and subsequent immunity to the experimental disease being studied.

Spontaneous disease problems in other species of laboratory animals have been avoided by raising cesarianderived breeding animals in isolation rooms as a source of disease-free experimental animals $(1,2)$. This approach with monkeys is currently impractical for us because of the long generation time and the requirement of complete isolation from man as well as from other subhuman primates. 102 
To circumvent the obstacles, therefore, we were forced to raise germfree monkeys. The only previous reports dealing with germfree monkeys record the raising of 2 Macaca mulatta to 1 and 4 months of age respectively $(3,4)$ and 1 Macaca mulatta to 15 days of age (5).

\section{Materials and Methods}

Cynomolgus (Macaca fascicularis) monkeys were selected for this investigation because pregnant females are commercially available throughout the year and because in our experience they have a lower incidence of spontaneous tuberculosis and pulmonary acariasis than rhesus monkeys. Seventeen pregnant females were purchased from animal dealers and 9 were bred in our own colony of conditioned monkeys. Nine of the first group (53\%) and 2 of the second group $(22 \%)$ aborted spontaneously.

Hysterectomies were performed on 10 monkeys and the infants delivered in flexible film isolators that had been previously sterilized. They were immediately dried, weighed and examined. The temperature inside the isolators was maintained at 28 to $30^{\circ} \mathrm{C}$ for 2 to 3 weeks after birth by use of heat lamps.

Four purchased monkeys and 1 conditioned monkey delivered naturally before hysterectomies could be performed. Two infants weighing 230 and 350 grams respectively were separated from their mothers and raised on sterile diets in 
a conventional laboratory environment. They were isolated from other monkeys and served as controls for the germfree study.

The following feeding schedule was found to be satisfactory for hand rearing both germfree and conventional cynomolgus monkeys. Starting 6 to 8 hours after birth the infants were fed 10\% glucose every 2 hours. At 18 to 20 hours after birth the diet was changed to a $2: 1$ mixture of a liquid human infant formula, Varamel (The Baker Milk Co., Cleveland, ohio), and 5\% glucose. This diet contained 0.75 calories/gram. Varamel alone ( 1.03 calories/gram) was fed from 2 to 3 weeks of age until solid food (Hill's prescription diet $\mathrm{C} / \mathrm{D}$, Hill Packing Co., Topeka, Kansas) was added to the diet at 4 months of age. Each infant was fed 10 times per day for 6 days. The number of feedings per day was gradually reduced to 6 at 3 weeks of age and to 4 at 6 weeks of age. All liquid diets were fed via a puppy nursing bottle and nipple. The solid food and Varamel. were sterile when purchased. A solid canned primate diet (Rx for Primates, Agway Inc., Syracuse, N.Y.) which was commercially avallable and advertised as sterile was not used. We demonstrated viable bacteria in all 4 cans cultured in our laboratory.

Tests for sterility included the culturing of feces, milk, and swabs from the floor of the cage, both aerobically and anaerobically, in both thioglycollate 
broth and on blood agar at 22,37 , and $55^{\circ} \mathrm{C}$. In addition Lowenstein-Jensen's, mycoplasma (Difco PPIO base, 20\% equine serum, and 10\% yeast extract) and Sabouraud's media were used. Material collected from the cage floors and by cutaneous swabs was inoculated into primary simian and feline kidney cell cultures.

\section{Results}

Three infants, 2 males and a female, were successfully raised under germfree conditions. They weighed 329,348 , and 375 grams at birth. They were considered to be mature infants based on body size and weight, strength, length and distribution of body hair and absence of respiratory distress. Respiratory rates during the neonatal period ranged from 80 to $100 / \mathrm{min}$. Their feces were soft and semisolid. All 3 germfree monkeys had an initial drop in body weight but then grew steadily and surpassed their birth weights on the 6 th to 9 th day. Their growth was corparable or superior to control monkeys raised on the same diet (Table 7). They were maintained as germfree animals for 2 , 9, and 12 months respectively.

The feeding habits and attitudes of the 3 germfree monkeys were similar during the hand-feeding period. Although conventionally raised cynomolgus infants were capable of self-feeding from a bottle at 2 weeks of age, the germfree infants were intentionally hand-fed until they 
Table 7. Weights of Germfree and Control Cynomolgus Monkeys (grains)

\begin{tabular}{|c|c|c|c|c|}
\hline \multirow[t]{2}{*}{ Age } & \multicolumn{3}{|c|}{ Germfree } & \multirow[t]{2}{*}{ Control ${ }^{2}$} \\
\hline & $I$ & 2 & 3 & \\
\hline Birth Weight & 375 & 348 & 329 & 350 \\
\hline 3 days & 333 & 324 & 300 & 340 \\
\hline 1 week & 357 & 357 & 357 & 352 \\
\hline 4 weeks & 566 & 515 & 550 & 519 \\
\hline 8 weeks & $783^{b}$ & 712 & 765 & 730 \\
\hline 12 weeks & & 890 & 910 & 850 \\
\hline 16 weeks & & 950 & 1065 & 975 \\
\hline 20 weeks & & 1074 & 1190 & 1060 \\
\hline 24 weeks & & 1178 & 1396 & 1108 \\
\hline 28 weeks & & 1288 & 1526 & 1182 \\
\hline 32 weeks & & 1423 & 1661 & 1350 \\
\hline 36 weeks & & 1510 & 1745 & 1455 \\
\hline 40 weeks & & 1605 & & 1570 \\
\hline
\end{tabular}

${ }^{a}$ A naturally delivered monkey raised in a conventional laboratory environment on the same sterile diet as the germfree monkeys.

${ }^{b}$ Accidentally contaminated at 2 months of age. 
could eat readily from a dish. The daily caloric intake was maintained at 175 to 200 calories $/ \mathrm{kg}$ body weight. At each feeding during the first 2 to 3 weeks the infants ate without hesitation. Each monkey periodically resisted the hand-feeding, however, from approximately 3 weeks of age until self-feeding was started. The resistance was expressed both vocally and physically. This behavior was reduced considerably if the animal was consistently handled by the same technician. Two monkeys appeared to receive a comforting and protective sensation from a knotted towel which was placed in the cage. One of the 2 had a choice between a cloth surrogate and a towel but always chose the towel. The third animal rarely exhibited a fear reaction and appeared comforted in the hands of a technician. All 3 monkeys periodically sucked their thumbs. One of 2 males consistently held his penis and scrotum in both hands when excited.

The germfree monkeys developed normally and resembled conventionally raised monkeys of comparable age except for their greater size and weight and freedom from cutaneous lesions. They were easily handled and never attempted to bite. They still sucked their thumbs periodically and appeared to receive a comforting sensation from a towel. The feces were soft and semi-solid. There was no evidence of enlarged cecums by abdominal palpation. 
No evidence of parasitism was detected by fecal flotation. At necropsy following hysterectomy 2 mothers had pulmonary acarlasis and numerous lesions of oesophagostomiasis. AlI 3 mothers came from our breeding colony of conditioned monkeys.

Deciduous tooth eruption in the germfree cynomolgus monkeys (Table 8) occurred at times comparable to those reported for conventionally raised rhesus monkeys. All the deciduous teeth had erupted by 6 months of age.

of the other 7 infants deliverea in germfree isolators 6 died within 4 days after delivery and the seventh monkey died on the twelfth day. The latter infant weighed 303 grams on the third day and appeared strong. He was fed only 6 times per day and usually ate less than $5 \mathrm{ml}$ per feeding. He developed complete anorexia on the seventh day and refused to eat thereafter. Four of the other 6 infants were slightly premature (average weight = 280 grams) and died within 2 to 4 days. Deep abdominal breathing indicative of respiratory distress was evident in all 4 monkeys and pulmonary edema was a consistent histopathologic finding. Early in the study, misinterpretation of external signs in the mother as those of Impending parturition prompted 2 hysterectomies several days before term. The infants were sparsely haired and weighed 150 to 160 grams respectively. They lived only a few hours. 
Table 8. Deciduous Tooth Eruption in Germfree Cynomolgus Monkeys

\begin{tabular}{|c|c|c|c|}
\hline$\frac{\text { Birth Weight, grams }}{\text { Sex }}$ & Male & $\frac{348}{\text { Female }}$ & $\frac{329}{\text { Male }}$ \\
\hline \multicolumn{4}{|l|}{ Incisors } \\
\hline \multirow[t]{2}{*}{ Central, } & 6 days & 22 days & 27 days \\
\hline & 14 days & 26 days & 24 days \\
\hline \multirow[t]{2}{*}{ Iateral, } & 21 days & 35 days & 24 days \\
\hline & 39 days & 31 days & 41 days \\
\hline Canine & 12th week & 14 th week & I4th week \\
\hline Molar 1 & 13th week & 14th week & 15th week \\
\hline Molar 2 & 22nd week & 24 th week & 24 th week \\
\hline
\end{tabular}




\section{Discussion}

Germfree techniques were easily applied to cynomolgus monkeys. The greatest difficulty was in selecting the time for hysterectomy. Reliable external signs of impending parturition were seldom detected. Most females had a slight mucoid vaginal discharge and lactation for several days before parturition or hysterectomy. Daily abdominal palpation and periodical rectal palpation eventually proved successful for evaluating the state of gestation and impending parturition.

Surprisingly little information could be found in the literature about the birth weight or early development of cynomolgus monkeys. In our experience, birth weights of cynomolgus and rhesus monkeys vary considerably and are related directly to the body weight of the mother and to the length of gestation. The results of this study suggest that mature cynomolgus monkeys usually weigh at least 325 grams at birth. We have recorded birth weights as low as 225 grams in naturally delivered monkeys, however, that were apparently at term based on strength, length and distribution of body hair, neonatal growth curve, and absence of respiratory distress.

To obtain germfree monkeys it is desirable to have a conditioned date-mated breeding colony. Pregnant monkeys which are purchased from commercial sources frequently abort spontaneously or deliver small weak infants. 


\section{Summary}

The techniques used for raising germfree rodents, dogs and cats were readily applied to the monkey. Three cynomolgus monkeys were raised under germfree conditions for 2, 9, and 12 months respectively. These animals grew as well or faster than those raised in a conventional laboratory environment and were similar in appearance and behavior. 
CHAPTER IV

RESISTANCE OF A GERMFREE MONKEY TO

HUMAN VIRAL HEPATITIS

Introduction

Although spontaneous and experimental viral

hepatitis has been studied for many years, the etiology and pathogenesis are still poorly understood. One of the major problems impeding progress in infectious hepatitis research has been the absence of suitable experimental animals. An experimental animal model would serve as (a) a tool for studying the sequential development of lesions, (b) an in vivo system for evaluation of "candidate viruses," (c) a potential source of susceptible cell. -cultures, and (d) a means of studying prevention and treatment of the disease.

Many nonprimate and subhuman primate species have been tested for susceptibility to human infectious hepatitis but with disappointing results $(2,4,5)$. In a comprehensive review of transmission studies prior to 1954, Evans (4) found no unequivocal evidence for successful transmission of infectious hepatitis from man to subhuman primates. In recent years, however, the disease has been experimentally induced in patas (10), cynomolgus (8) and marmoset (3) monkeys and in chimpanzees (1). With the 
possible exception of marmosets, however, infectious hepatitis was reproduced sporadically, possibly because many of the animals were previously exposed to the human disease, to a carrier of the disease, or to a closely related agent. To eliminate naturally acquired immunity as a factor affecting experimental reproduction of the disease, a study was designed to determine the susceptibility of a germfree cynomolgus monkey to human viral hepatitis.

\section{Materials and Methods}

A male germfree cynomolgus monkey was inoculated intraperitoneally at 9 months of age with $1.6 \mathrm{ml}$ of serum from a human patient with acute, experimentally produced infectious hepatitis. The human volunteer had been injected with serum from a person with naturally occurring infectious hepatitis. In both patients the diagnosis was made by correlating clinical symptoms, liver function tests, and the histopathologic appearance of liver needle biopsies. Serum from the human volunteer produced the disease in several other volunteers following inoculation by the intramuscular, intraperitoneal or oral routes.

The techniques for raising germfree monkeys have been previously reported (11). The monkey was housed in a rigid plastic, negative-pressure germfree isolator to minimize risk to the investigators. 
The serum enzyme activities of glutamic oxalacetic transaminase (SGOT), glutamic pyruvic transaminase (SGPT), and lactic dehydrogenase (IDH) were determined by the methods of Karmen et al. (7), Wroblewski and LaDue (13) and Wroblewski and LaDue (12) respectively. They were measured bi-weekly for the first 4 weeks and weekly thereafter until termination of the experiment at 11 weeks. Liver biopsies were performed on the same days that serum enzyme values were determined. The blopsies were performed via the transpleural route (eighth or ninth right intercostal space) using a Menghini needle. The liver tissue was divided and portions were fixed in cold buffered formalin and in Carnoy's solution for histopathologic examination.

Euthanasia and a complete necropsy were performed 11 weeks after inoculation. Representative sections from all tissues were fixed in cold buffered formalin, embedded in paraffin, sectioned at $6 \mathrm{u}$, and stained with hematoxylin and eosin. Liver, spleen, colon and brain were cultured by established sterility testing procedures (11) to confirm the gnotobiotic status of the monkey.

\section{Results}

No clinical signs or significant biochemical changes were recognized during the 11 week observation period. The 
means of the serum enzyme values were comparable to the three baseline values for each enzyme and are listed in Table 9. No lesions were detected in the biopsied liver tissue and no significant lesions were found in any of the tissues collected at necropsy.

No micro-organisms were cultured from the liver, spleen, colon and brain. The histological appearance of the lymphoid tissues, lung and intestine was compatible with that of other germfree animals.

\section{Discussion}

Human viral hepatitis was not reproduced in a germfree cynomolgus monkey. In the absence of a suitable virus assay method no attempt was made to determine whether virus replicated in the monkey or if neutralizing antibodies formed.

Naturally acquired immunity had been suggested as a major factor preventing consistent transmission of viral hepatitis to subhuman primates $(3,10)$. It was proposed that exposure of the animals might have occurred either in their native habitat or following contact with man. Since the disease was not produced in the germfree monkey with an inoculum known to be infectious, naturally acquired immunity was eliminated as the sole factor responsible for the resistance of an experimental animal to human viral hepatitis. The original inoculum had reproduced the disease in human volunteers and in a patas monkey (10). 
Table 9. Serum Enzyme Values ${ }^{a}$ of a Monkey Exposed to Human Infectious Hepatitis Virus

\begin{tabular}{lrr}
\hline Test & Mean & Range \\
\hline SGOT & 29.0 & $21.2-38.5$ \\
SGPT & 16.2 & $8.7-27.0$ \\
LDH & 282.2 & $120.5-443.4$
\end{tabular}

$a_{\text {Expressed as International Units/liter. }}$ 
There are several other factors which could account for the apparent resistance of the germfree monkey to experimentally induced human viral hepatitis including: (a) absence of a previously damaged liver, (b) variation in monkey species specificity among the strains of hepatitis virus, (c) absence of microbial flora, (d) Innate Immunity, (e) passive immunity transferred in utero, and (f) a prolonged incubation period. If liver damage were a prerequisite for the expression of hepatitis, as previously suggested (3), the healthy liver of a germfree monkey could not provide a suitable medium for the infectious agent. The role of species specificity should be determined by testing several inoculums including the "candidate viruses" in several species of monkeys under ldentical conditions. To emphasize the potential importance of microbial flora canine distemper (6) and feline infectious enteritis (9) were described as very mild diseases in germfree animals with complete paucity of the lesions which characterize the naturally occurring and experimental diseases in conventional dogs and cats. Iikewise, microbial flora may be necessary for the expression of hepatitis in subhuman primates. It is very unlikely that passive immunity was a factor in this study since the monkey was exposed at 9 months of age. The possibility of the incubation period being longer than 11 weeks must be considered although the original inoculum had induced the disease in a monkey 7 weeks after inoculation (10). 
Deinhardt et al. (3) have recently described a potentially suitable experimental animal model for human viral hepatitis. They have consistently induced biochemical and morphologic hepatitis in marmoset monkeys. Although the liver lesions in the marmosets have not been identical with human viral hepatitis, several changes characteristic of the human disease have been observed including morphologic variations among neighboring hepatocytes, acidophillc bodies, focal necrosis, portal inflammation with bile duct hyperplasia and hepatic phlebitis.

\section{Summary}

A germfree cynomolgus monkey was inoculated intraperitoneally with infective serum from a human patient with infectious hepatitis. Serial liver biopsies were performed and serum enzyme values were determined for SGOT, SGPT and LDH. No clinical signs or significant biochernical changes were recognized during the 11 week study. Macroscopic and microscopic lesions were absent. 


\section{BIBLIOGRAPHY}

\section{Chapter I}

1. McKissick, G. E., Griesemer, R. A., and Farrell, R. I.: Aerosol. transmission of Rauscher leukemia in mice. Unpublished data.

2. Sevoian, M., Chamberjain, D. M., and Iarose, R. N.: Avian lymphomatosis V. Air-borne transmission. Avian Dis. 7:102-105, 1963.

3. Burmester, B. R. and Gentry, R. F.: A study of possible avenues of infection with the virus of avian visceral lymohomatosis. Proc. AVMA, 91st Ann. Meeting:311-316, 1954 .

4. Andrewes, C. H., Allison, A. C., Armstrong, J. A., Bearcroft, G., Niven, J.S. F., and Pereira, H. G.: $A$ virus disease of monkeys causing large superficial growths. Acta Un. Int. Contra Cancrum 15:760-763, 1959.

5. Niven, J. S. F., Armstrong, J. A., Pereira, H. G., and Valentine, R. C.: Subcutaneous "growths" in monkeys produced by a poxvirus. J. Path. Bact. 81: $1-14,1961$.

6. Woodroofe, G. M. and Fenner, F.: Serological relationships with poxvirus group: an antigen common to all members of the group. Virology 16:334-341, 1962 .

7. Bearcroft, W. G. C. and Jamieson, M. F.: An outbreak of subcutaneous tumors in rhesus monkeys. Nature $182: 195-196,1958$.

8. Yohn, D. S., Marmol, F. R., Haendiges, V. A., and Grace, J. T.,Jr.: Yaba tumor poxvirus synthesis in vitro. II. Adsorption, inactivation, and assay studies. J. Bact. 91:1953-1958, 1966.

9. Sproul, E. E., Metzgar, R. S., and Grace, J. T.: The pathogenesis of Yaba virus-induced histiocytomas in primates. Cancer Res. 23:671-675, 1963.

10. Grace, J. T., Jr. and Mirand, E. A.: Human susceptibility to a simian tumor virus. Ann. N.Y. Acad. Sci. 108:1123-1128, 1963. 
11. Wolfe, I. G.: Immunologic response of monkeys to aerosols of Yaba virus. Chapter II, Dissertation.

12. Ambrus, J. I., Feltz, E. T., Grace, J. T., Jr., and Owens, G.: A virus-induced tumor in primates. Conference on Biology of Cutaneous Cancer. Nat. Cancer Inst. Monogr. 10:447-458, 1963.

13. Wolfe, I. G.: Germfree cynomolgus monkeys. Chapter III, Dissertation.

14. Yohn, D. S., Haendiges, V. A., and Grace, J. T., Jr.: Yaba tumor poxvirus synthesis in vitro, I. Cytopathological, histochemical, and immunofluorescent studies. J. Bact. 91:1977-1985, 1966.

15. Henderson, D. W.: An apparatus for the study of airborne infection. J. Hyg. 50:53-68, 1952.

16. Roessler, H. G. and Kautter, D. A.: Modifications to Henderson apparatus for stuajing air-borne infections. Evaluations using aerosols of Listeria monocytogenes. J. Inf. Dis. 110:17-22, 1962 .

17. Andersen, A. A.: New sampler for the collection, sizing, and enumeration of viable airborne particles. J. Bact. $76: 471-484,1958$.

18. Stahl, H. R., and Malinow, M. R.: A survey of physiological measurements in Macaca mulatta. Folia Primat. $7: 12-33,1967$.

19. Hatch, T. F.: Distribution and deposition of inhaled particles in respiratory tract. Bact. Rev. 25:237$240,1961$.

20. Palm, P. E., Mclverney, J. M., and Hatch, T.: Respiratory dust retention in smali animals. Arch. Industrial Health $13: 355-365$, 1956.

21. Grinker, J. A., Karlin, D. A., and Estrella, P. M.: Lung mites: pulmonary acariasis in the primate. Aerospace Med. 33:841-845, 1962 .

22. Innes, J. R. M., Colton, M. W., Yevich, P. P., Smith, C. L.: Pulmonary acariasis as an enzootic disease caused by pneumonysslis simicola in imported monkeys. Amer. J. Path. 30:813-835, 1954. 
23. Ross, M. A., Gainer, J. H., and Innes, J. R. M.: Dystrophic calcification in the adrenal glands of monkeys, cats and dogs. Arch. Path. 60:655-662, 1955.

24. de Harven, E. and Yohn, D. S.: The fine structure of the Yaba monkey tumor poxvirus. Cancer Res. 26:995$1008,1966$.

25. Noyes, W. F.: Observations on two pox-tumor viruses. Virology $25: 666-669,1965$.

26. Owens, G., Metzgar, R., and Grace, J. T.: Electron microscopy of "Yaba Virus." Clinical Res. 11:212, 1963.

27. Owens, G., Metzgar, R., and Grace, J. T.: Ultrastructure and related inmunologic characterlstics of the Yaba virus. J. Surgical Res. 4:297-305, 1964.

28. Owens, G., Metzgar, R. S.g and Grace, J. T.: Electron microscopy of Yaba virus: Surgical Forum 14:44-45, 1963.

29. Balis, J. U. and Conen, P. E.: The role of alveolar inclusion bodies in the developing lung. Iab. Invest. 13:1215-1229, 1964 .

30. Karrer, H. E.: The ultrastructure of the mouse lung, general architecture of capillary and alveolar walls. J. Biophys. Biochem. Cytol. 2:241-252, 1956.

31. Kuhn, C., Györkey, F., Levine, B. E., and Rarnirez-Rivera, J.: Pulmonary alveolar proteinosis. Lab. Invest. 15:492-509, 1966 .

32. Schulz, H.: Die submicroscopische anatomie und pathologie der lunge. Berlin, Springer-Verlag, 1959.

33. Sorokin, S. P.: A morphologic and cytochemical study on the great alveolar cell. J. Histochem. Cytochem. $14: 884-897,1967$.

34. Chevilie, N. F.: The cytopathology of swine pox in the skin of swine. Amer. J. Path. 49:339-352, 1966.

35. Casey, H. W., Woodruff, J. M., and Butcher, W. I.: Electron microscopy of a benign epidermal pox disease of rhesus monkeys. Amer. J. Path. 51:431-446, 1968.

36. Cheville, N. F.: Cytopathologic chances in fowlpox (turkey origin) inclusion body formation. Amer. J. Path. 49:723-737, 1966. 
37. Acton, J. D. and Myrvik, Q. N.: Production of interferon by alveolar macrophages. J. Bact. 91:2300$2304,1966$.

38. Isaacs, A., and Hitchcock, G.: Role of interferon in recovery from virus infection. Lancet: 69-71, 1960.

39. Montagna, W., Yun, J. S., and Machida, H.: The skin of primates VIII. The skin of the rhesus monkey

(Macaca mulatta). Am. J. Phys. Anthrop. 22:307-320, 1964.

40. Munroe, J. S., Shipkey, F., Erlandson, R. A., and Windle, W. F.: Tumors induced in juvenile and adult primates by chicken sarcoma virus. Nat. Cancer Inst. Monogr. 17:365-390, 1964.

41. Yamanouchi, K., Fukuda, A., Kobune, F., Uchida, N., Tsuruhara, T.: Oncogenicity of Schrnidt-Ruppin strain of Rous sarcoma virus in cynomolgus monkeys. Jap. J. Med. Sci. \& Biol. 20:443-446, 1967.

42. Bucciarelli, E., Rabotti, G. F., and Dalton, A. J.: Ultrastructure of meningeal tumors induced in dogs with Rous sarcoma virus. J. Nat. Cancer Inst. 38:359381, 1967.

43. Bucciarelli, E., Rabotti, G. F., and Da.Iton, A. J.: Ultrastructure of Gliomas induced in hansters vith Rous sarcoma virus. J. Nat. Cancer Inst. 38:865-889, 1967.

44. Hinz, R. W., Barski, G., and Bernhard, W.: An electron microscopic study of the development of the encephalomyocarditis (EMC) virus propagated in vitro. Exp. Cell Res. 26:571-586, 1962 .

45. Stuart, D. C., Jr., and Fogh, J.: Electron microscopic demonstration of intracellular poliovirus crystals. Exp. Cell Res. 18:378-381, 1959.

46. Stuart, D. C., Jr., Fogh, J., and Plager, H.: Cytoplasmic crystals in FL cells infected with an unclassified enteric virus (presumably a new type of ECHO). Virology $12: 321-324,1960$.

47. Nakagami, K.: Comparative electron microscopic studies of the parathyroid gland, I. Fine structure of monkey and dog parathyroid glands. Arch. Histol. Jap. 25: $435-466,1965$. 


\section{Chapter II}

1. Bearcroft, W. G. C. and Jamieson, M. F.: An outbreak of subcutaneous turnors in rhesus monkeys. Nature 182: 195-196, 1958.

2. Grace, J. T., Jr. and Mirand, E. A.: Human susceptibility to a simian tumor virus. Ann. N.Y. Acad. Sci. 108:1123-1128, 1963 .

3. Ambrus, J. L., and Strandstrom, H. V.: Susceptibility of old world monkeys to Yaba virus. Nature 211:876, 1966.

4. Ambrus, J. L., Feltz, E. T., Grace, J. T., and Owen, G.: A virus-induced tumor in primates. Conference on biology of cutaneous cancer. Nat. Cancer Inst. Monogr. $10: 447-458,1963$.

5. Niven, J. S. F., Armstrong, J. A., Pereira, H. G., and Valentine, R. C.: Subcutaneous "growths" in monkeys produced by a poxvirus. J. Path. Bact. 81: $1-14,1961$.

6. Sproul, E. E., Metzgar, R. S., and Grace, J. T.: The pathogenesis of Yaba virus-induced histiocytomas in primates. Cancer Res. 23:671-675, 1963.

7. Metzgar, R. S., Grace, J. T., and Sproul, E. E.: Immunologic studies of subcutaneous virus-induced histiocytomas in primates. Ann. N.Y. Acad. Sci. 101:192-202, 1962.

8. Wolfe, I. G.: Experimental aerosol transmission of Yaba virus in monkeys. Chapter I, Dissertation.

9. Sever, J. I.: Application of a microtechnique to viral serological investigations. J. Immun. 88:320-329, 1962.

10. Yohn, D. S.: Personal communication.

11. I.evintha1, J. M. and Shein, H. M. Propagation of a simian tumor agent (Yaba virus) in cultures of human and simian renal cells as detected by immunofluorescence. Virology 23:268-270, 1954.

12. Taylor, D. O. N., Klauber, M. R., Lennette, E. H., and Wiener, A.: An immunofluorescent method for Yaba virus assay. J. Nat. Cancer Inst. 40:147-155, 1968.

13. Yohn, D. S., Haendiges, V. A., and Grace, J. T., Jr.: Yaba tumor poxvirus synthesis in vitro, I. Cytopathological, histochemical, and immunofluorescent studies. J. Bact. 91:1977-1985, 1966. 


\section{Chapter III}

1. Griesemer, R. A. and Gibson, J. P. The gnotobiotic dog. Iab. Ani. Care, 13 (1963):643-648.

2. Rohovsky, M. W., Griesemer, R. A., and Wolfe, I. G. The germfree cat. Iab. Ani. Care, 16'(1966): 52-59.

3. Reyniers, J. A., 1952. Rearing of a caesarian-born M. rhesus monkey under sterile conditions. A preíminary report. J. Bact., 43(1952):778.

4. Reyniers, J.A. and Trexler, P. C., 1943. Micrurgical and germfree methods. Thomas, Springfield, p. 136.

5. Brant, H. G., Kundzins, W., Reese, W. H., and Kerber, W. T., 1963. The gnotobiotic primate. Procedures involving adaptation and maintenance in a germfree environment. Lab. Ani. Care, 13(1963):557 (Abs).

\section{Chapter IV}

1. Atchley, F. 0. and Kimbrough, R. D.: Experimental study of infectious hepatitis in chimpanzees. Lab. Invest. 15 (1966): 1520-1527.

2. Communicable Disease Center. Hepatitis surveillance report No. 26 (1966):20-21.

3. Deinhardt, F., Holmes, A. W., Capps, R. B., and Popper, H.: Studies on the transmission of human viral hepatitis to marmoset monkeys. I. Transmission of disease, serial passages, and description of liver lesions. J. Expt1. Med., 125 (1967):673-688.

4. Evans, A. S.: Attempts to transmit the virus of human hepatitis to primates other than man. Nat. Acad. Sc1.Nat. Res. Council Publ. No. 322, Washington, D. C. $(1954): 58$.

5. Findlay, G. M., Mac Callum, F. O., and Murgatroyd, F.: Observations bearing on the etiology of infective hepatitis (so-called epidemic catarrhal jaundice). Trans. Roy. Soc. Trop. Med. Hyg., 32 (1939):575-586.

6. Gibson, J. P., Griesemer, R. A., and Koestner, A.: Experimental distemper in the gnotobiotic dog. Path. Vet., 2 (1963): $1-19$. 
7. Karmen, A., Wroblewski, F., and LaDue, J. S.: Transaminase activity in human blood. J. Clin. Invest., 34 (1955):126-133.

8. McLean, I. W., Jr.: Clinical significance of recent investigations of hepatitis viruses. Postgrad. Med., 35 (1964): 481 .

9. Rohovsky, M. W. and Griesemer, R. A.: Experimental feline infectious enteritis in the germfree cat. Path. Vet., 4 (1967):391-410.

10. Smetana, H. F.: Experimental and spontaneous viral hepatitis in primates. Lab. Invest., 14 (1965):13661374 .

11. Wolfe, L. G.: Germfree cynomolgus monkeys. Chapter III, Dissertation.

12. Wroblewski, F. and IaDue, J. S.: Iactic dehydrogenase activity in blood. Proc. Soc. Expt1. Biol. \& Med., 90 (1955):210-213.

13. Wroblewski, F. and LaDue, J. S.: Serum glutamic pyruvic transaminase in cardiac and hepatic disease. Proc. Soc. Expt1. Biol. \& Med., 91 (1956):569-571. 